\title{
A szülói nevelói stílus azonosítására alkalmas Parenting Styles and Dimensions Questionnaire hazai alkalmazásával szerzett tapasztalatok
}

\author{
HADHÁZI ÉVA ${ }^{1 *}$ - TAKÁCS SZABOLCS² - CSIKÓS GÁBOR ${ }^{1}$ - \\ HOMOKI ADÉL ${ }^{3}$ - CZINKÓCZKI ANNAMÁRIA - \\ TÖRÖ KRISZTINA ${ }^{1}$ - KÖVESDI ANDREA ${ }^{1}$ - F. FÖLDI RITA ${ }^{1}$ \\ ${ }^{1}$ Károli Gáspár Református Egyetem, Pszichológiai Intézet, \\ Fejlődéslélektani Tanszék, Budapest \\ ${ }^{2}$ Károli Gáspár Református Egyetem, Pszichológiai Intézet, Általános Lélektani \\ és Módszertani Tanszék, Budapest \\ ${ }^{3}$ Károli Gáspár Református Egyetem, Pszichológiai Intézet, \\ Budapest, egyetemi hallgató
}

(Beérkezett: 2020. október 1.; elfogadva: 2021. március 21.)

Elmélet: A gyermekek egészséges testi, lelki fejlődésének támogatása a szülői vágyakon túlmutató társadalmi érdek. Az 1950-es évektől kezdve élénk kutatási érdeklődés övezi a szülői nevelői stílusnak a gyermek fejlődésére gyakorolt hatásvizsgálatát, ám a szülői nevelői stílust befolyásoló tényezőkről kevesebb eredmény áll a rendelkezésünkre. A tanulmány célja: a Parenting Styles and Dimensions Questionnaire (PSDQ) kérdóív magyar mintán történő kipróbálása, és a szülői nevelői stílus lehetséges szociodemográfiai, párkapcsolati és pszichoszociális összefüggéseinek vizsgálata volt. Módszerek: 711 fós (113 férfi, 598 nó, átlagéletkor 34,8 [SD = 10,91] év) önbeszámolós, keresztmetszeti vizsgálatunkban a PSDQ 32 tételes kérdőív mellett felvettük az Intim Kötődés Mérésére kidolgozott kérdőívet, a Kapcsolati Elégedettség Skálát, a Közvetlen Kapcsolatok Élményei kérdőívet, a STAI Vonásszorongás, a Zung-féle Önértékelő Depresszió Skálát, valamint a MOS Társas Támasz Kérdőívet. Eredmények: a konfirmatív faktorelemzés a PSDQ-HU önmagára és párjára vonatkoztatott változatának megbízható faktorstruktúráját igazolta (Saját - Self: SRMR =0,065, RMSEA =0,059, TLI = 0,796, CFI = 0,818; Másik - Other: SRMR $=0,066, \mathrm{RMSEA}=0,063, \mathrm{TLI}=0,890, \mathrm{CFI}=0,902)$. A Tekintélyelvü és Irányító skálák belső reliabilitása megfeleló (Cronbach- $\alpha=0,73-0,95)$, a nemzetközi tapasztalatokhoz hasonlóan a Megengedő skála Cronbach- $\alpha$ értéke alacsonyabb $(0,64)$. Az alskálák: Testi fenyítés, Verbális ellenségesség, Indokolatlan büntetés, Melegség, Érvelés, Demokratikus részvétel Cronbach- $\alpha$ értéke 0,54-0,93 között mozog. A nem, a családi állapot, valamint az, hogy valaki egyedüli gyermekként nő-e fel, szerepet játszhat a szülői nevelói stílusában. A PSDQ-HU több kérdőívvel mutatott szignifikáns $(p<0,05)$ együttjárást. A párkapcsolati intimitás $(r=-0,38-0,62)$, a felnőtt kötődés biztonsága $(r=-0,31--0,57)$, a párkapcso-

\footnotetext{
* Levelező szerző: dr. Hadházi Éva, Károli Gáspár Református Egyetem, Pszichológiai Intézet, Fejlődéslélektani Tanszék, 1037 Budapest, Bécsi út 324. V. ép. E-mail: hadhazi.eva@kre.hu
} 
lattal való elégedettség $(r=-0,39-0,58)$ együtt jár azzal, hogy milyen szülőnek észleli valaki a párját. A vonásszorongás és a Zung-féle depresszió kérdőíven elért pontok a pár szülőként való negatívabb észlelésével korrelálnak $(\mathrm{r}=-0,33--0,38)$. A minél erősebb társas támasz észlelete a párra vonatkoztatott pozitívabb szülói percepcióval jár együtt $(r=0,36-0,46)$. Az önmagára vonatkoztatott szülői nevelői stílus nem mutat szignifikáns összefüggést egyetlen vizsgált skálaváltozóval sem, csak a nemmel és a testvér nélküli felnövekedéssel. Következtetések: A PSDQ-HU kérdőív az önmagunk szülőként való észlelése mellett alkalmas a párunk szülőként való észlelésének a monitorozására, s bár nem párokat vizsgáltunk, eredményeink felhívják a figyelmet a mentális állapot, a párkapcsolat minőségének percepciója és a pár szülői nevelői stílusának észlelete közötti kapcsolatra, amely a pszicho- edukációban és a családokkal, párokkal dolgozó szakemberek számára nyújthat hasznos támpontot.

Kulcsszavak: szülői nevelői stílus, párkapcsolati intimitás, párkapcsolati elégedettség, felnőtt kötődés, mentális jóllét, társas támasz

\section{Bevezetés}

\subsection{A nevelői stílus fogalma és mérési lehetőségei}

A gyermekek személyiségének fejlődését befolyásoló tényezők közül a legfontosabb szocializációs közeg a család, a ,jelentős mások" elsődleges csoportja (Papp-Zipernovszky, Kékesi, \& Jámbori, 2017). A család által biztosított lelki és társas erőforrás beépül az egyén identitásába, amelynek formálásában elsődleges szerepet játszanak a szülők, hiszen a gyermekeikkel kialakított érzelmi kapcsolat nyújtia a biztonságot, az útravalót az élethez, és minden további kapcsolódás alapmintájául szolgál (Cowan \& Cowan, 2009). Azzal együtt, hogy a család történelmi, társadalmi és kulturális beágyazottsága hatással van a családi rendszer múködésére, a családtagok egymással való interakciójának minőségére, a szülői felelősség megkérdőjelezhetetlen. Alt (1995) találó megfogalmazása szerint a családban szerzett tapasztalatoknak az egyéni életminőségen túlmutató, társadalomformáló szerepük van, a családi szocializáció eredményeképpen felnövekvő generációk válnak a társadalom további alakítóivá. Érvelése szerint az „apa-anyagyermek viszony jó minősége előfeltétele a társadalmon belüli egészséges, emberibb kapcsolatoknak" (Alt, 1995, 7. o.).

Az egyedfejlődés optimális esetben családban történik, a gyermekek betagozódnak, miközben alakítják azt a családi miliőt, ahová érkeznek, a párt szülővé, a szülőket nagyszülővé avatva, új hierarchiát hoznak létre a rendszerben. Ezek a változások természetesnek tekinthetók és az általuk támasztott kihívásokkal való megküzdés, a fejlődési krízisen való felülkerekedés pedig erőforrás és egyben mintául is szolgál a családon kívüli élethelyzetek megoldásához is. 
Erikson (1968) egyetemes érvényú pszichoszociális fejlődéselméletében a felnőttség fő feladata, s egyben krízispotenciálja a generativitás (alkotóképesség), szemben a stagnálással. A krízis megoldása azonban az adott kultúra által determinált, és akkor sikeres, ha kialakul a következő generációról való gondoskodás képessége. A gondoskodásnak része a gyermeknevelés, ami kultúránként és társadalmanként különböző elvárásokat támaszthat a szülókkel szemben. Sevinc és Garip (2010) véleménye szerint a gyermeknevelés fogalma meglehetősen összetett, a szülói gyakorlatokra, valamint a szülő és a gyermek közötti attitúdök, értékek, és hiedelmek kifejezését érintó interakciókra utal.

A szülőkben - valószínúleg kultúrától függetlenül -, ott él a vágy, az "elég jó szülőség"-re (Winnicott, 1999), s az erre való törekvésük különböző forgatókönyveket szülhet. Egyrészt az eredeti családjukból hozott, gyermeknevelésról való vélekedéseiket, illetve alkalmazott nevelési eljárásokat mint követésre érdemest tovább vihetik; másrészt, ha nem tudnak e mintával azonosulni, ellene választanak, és az ellenkezőjét teszik - vagy legalábbis próbálják tenni - annak, amiben ők részesültek. Harmadrészt új megoldásokat tanulva próbálják kialakítani a saját nevelési stílusukat, miközben megőrizik a kedvezőt és elengedik a túlhaladott szülői mintákat.

Mára a szülői nevelői stílusok kutatása igen elterjedt a nemzetközi porondon, számos kapcsolatot feltártak úgy a szülői, mint a gyermeki oldal jellemzőit illetően.

A pszichológiai kutatások a szülői nevelési stílus definiálásakor három fő tényezőre helyezték a hangsúlyt: (1) a szülő által gyakorolt nevelési módszerekre, eljárásokra; (2) a szüló nevelési elveire, nézeteire és gyakorlatára; valamint (3) a szülő és a gyermek közötti érzelmi kapcsolatra (Darling \& Steinberg, 1993). Jelen munkában csupán a Robinson, Mandleco, Olsen és Hart (2001) által kidolgozott Parenting Styles and Dimensions Questionnaire (PSDQ; Szülői Nevelői Stílus Kérdőív) történeti előzményeinek bemutatására térünk ki, a szülói nevelói stílus különböző pszichológiai megközelítéseinek tárgyalásától eltekintünk, ezek ismertetését Perger (2002) munkájában lehet nyomon követni.

Az 1950-es évek végétől Schaefer $(1959,1965)$ próbált egy átfogó modellt nyújtani a szülői viselkedésekről, jellemzően dichotóm jellemzők mentén: elfogadás vs. elutasítás, pszichológiai autonómia vs. kontroll, szigorú ellenőrzés vs. ellenőrzés hiánya. Becker (1964) két, egymástól független dimenziót határozott meg: egy érzelmit - ahol a „hideg, elutasító, rideg” és „meleg, szeretó, elfogadó" érzelmek képezik a dimenzió végpontjait - és egy viselkedésest - a dimenzió végpontjai: a „kontrolláló, szabályozó" és az „engedékeny, kevésbé szabályozó" viselkedések -, amelyek kombinációival lehetett leírni a különböző szülői múködéseket. Ezen munkákra alapozta Baumrind $(1966,1968)$ a szülői típusait, úgymint: tekintélyelvú (author- 
itarian), irányító (authoritative) és engedékeny (permissive), hogy segítségükkel leírja a szülői kontrollt (ami minden olyan törekvést magában foglal, amivel a szülő igyekszik elősegíteni a gyermeke beilleszkedését a családba, a társadalomba) és annak hatásait a gyermeki szocializációra. A késóbbiekben Maccoby és Martin (1983) ezeket kiegészítették az elhanyagoló (uninvolved) típussal, amit a válaszkész (responsiveness) és a megkívánó/ megköveteló (demandingness) dimenziók bevonásával határoztak meg. Az elhanyagoló stílust többféle megnevezéssel illették, maga Baumrind is, de tulajdonképpen ugyanazt a viselkedést értették alatta: kívülálló (unengaged: Baumrind, 1989, 1991), nem kapcsolódó (disengaged: Baumrind, Larzelere, \& Owens, 2010), elhanyagoló (neglecting: Steinberg, Lamborn, Darling, Mounts, \& Dornbusch, 1994), elutasító-elhanyagoló (rejecting-neglecting: Baumrind, 1989, 2013). A válaszkészség dimenzió a szülői elfogadást, támogatást, melegséget, a gyermek igényeire való ráhangolódást jelenti, míg a megkövetelés a szülői kontrollt vagy a hatalom gyakorlását (Maccoby \& Martin, 1983). Baumrind (2012, 2013) érvelése szerint ez utóbbi minőségileg különböző viselkedést jelent az egyes szülői stílusoknál, így a kontroll pozitív hatással van a gyermekre, amennyiben nyílt viselkedéssel konfrontálja a gyermeket a határozott kívánalmakkal, irányító, célvezérelt és használja az érvelést. A kényszerítő kontroll a hatalomgyakorlás negatív módja: tolakodó, durva, büntető, kedvezőtlen a gyermek fejlődése szempontjából; a pszichológiai módja pedig rejtett, manipulatív kontrollt jelent, ami aláássa a gyermek énképét. Ennek megfelelően úgy véli, hogy a négy szülői stílus konceptualizálásánál az elfogadás és elutasítás dichotómiáját (a válaszkészség és megkövetelés helyett) szerencsésebb lenne ezekkel a dimenziókkal megragadni: pszichológiai autonómia vs. kontroll, valamint határozott viselkedéses kontroll vs. laza viselkedéses kontroll.

Az alábbiakban röviden bemutatjuk, hogy mit is takarnak Baumrind (1971) empirikus alapokon nyugvó modelljének szülői nevelői stílusai, amelyek leírása az évek alatt egyre finomodott.

Az autoritatív/irányító (megkívánó) szülő: észszerú, meleg, bátorító és kontrolljával elősegíti a gyermek autonómiáját (Baumrind, 1966). A szülők és a gyermekek jogait kölcsönösnek tekintik, és a gyermek korának megfelelő elvárásokat támasztanak. Ritkábban alkalmaznak testi fenyítést, inkább elmagyarázzák, megbeszélik a szabályokat a gyermekkel, és megindokolják a döntéseiket, a tekintélynek való megfelelést nem hangsúlyozzák, nem tekintik önmagában való erénynek. Nyitottak a gyermek nézőpontjának a megismerésére, akkor is, ha nem mindig fogadják el. Magas elvárásokat támasztanak a gyermekkel szemben és motiválják a független viselkedésre (Cole, 2006). A szülők által hozott szabályok világosak és az érvelést használják a betartatásukra, bátorítják a nyílt kommunikációt, a gyermek függetlenségét, valamint a szeretet és az érzelmek kifejezését (Maccoby \& Martin, 1983). Baumrind szerint, ha figyelembe vesszük 
az elfogadás-elutasítás, viselkedéses és lelki kontroll - azaz a pszichológiai autonómia vs. kontroll - dimenziókat, akkor az autoritatív szülők magas értékeket érnek el az elfogadás és a viselkedéses kontroll dimenziókban, és alacsonyat a lelki kontrollban (Baumrind, 2013; Baumrind és munkatársai, 2010). Úgy ítélték meg, mint optimális szülői nevelői stílust, amely kedvező hatást gyakorol a gyermekekre az önállóság, a társas felelősségvállalás (Baumrind, 1971) és az alkalmazkodás (Baumrind és munkatársai, 2010) terén egyaránt.

Az autoritáriánus/tekintélyelvü (megkövetelö) szülóknek fontosak a hagyományos normák, a hangsúly nem az alkudozáson van, hanem a tekintélynek való (feltétlen) engedelmességen. Szigorúak, korlátoznak, értékelnek, megkövetelik a szabályok betartását, inkább parancsokat osztogatnak és a szabályok megszegését gyakran különböző méretú büntetések kiszabásával illetik (Cole, 2006). Az elutasítás és lelki kontroll dimenziókban magas értéket érnek el (Baumrind, 2013; Baumrind és munkatársai, 2010). Nagyon megkövetelőek, a viselkedési szabályok betartatását gyakran erővel, büntetéssel érik el (Baumrind, 1966), a szülői kontroll kényszerítő és uralkodó (Baumrind, 2012). Ez a stílus kevésbé optimális a gyermek fejlődése szempontjából, alacsonyabb énhatékonysággal (Baumrind és munkatársai, 2010), lázadással (Baumrind, 1968) és a problémák externalizálásával jár a gyermek részéról (Maccoby \& Martin, 1983; Rankin Williams és munkatársai, 2009). Az önkényes, kényszerító jellegú hatalomgyakorlás megtartja a családi kapcsolatokban a hierarchikus státusbeli különbségeket, a gyermeknek nincs más választása, csak a teljesítés (Baumrind, 2012).

A permisszív/engedékeny szülők elkerülik a kényszerító és konfrontatív megoldásokat, amennyire csak lehet (Baumrind, 1989), engedékenyek, a gyermek hozhatja meg a saját szabályait és döntéseit (Maccoby \& Martin, 1983). Szabadságot adnak a gyermekeiknek, nincs, vagy kevés a korlátozás, a határozott szabály. Rájuk bízzák a programjaik, időbeosztásuk tervezését, gyakran bevonják a családi döntésekbe, miközben nem várnak el tőlük olyan érett viselkedést és teljesítményt, mint az irányító vagy tekintélyelvú szülők. Ennek oka, hogy vagy azt vallják, hogy a gyermeknek a tapasztalataiból kell tanulnia, vagy csak terhesnek érzik a fegyelmezést (Cole, 2006). Ez a nevelói stílus alacsony teljesítményt (Baumrind, 1971), az impulzuskontroll hiányosságait (Maccoby \& Martin, 1983) és alacsonyabb autonómiát (individuáció és önhatékonyság) eredményez a gyermekeknél, kevésbé kompetensnek és jól múködőnek bizonyultak kamaszkorban, mint az autoritatív (konfrontatív kontrollt használó) szülők által nevelt gyermekek, a teljes elfogadás, elnéző gyakorlatok és a szüleik egyenlőséget képviselő értékrendje ellenére (Baumrind és munkatársai, 2010). Úgy túnik, hogy a korlátozás nélküli szabad választás határozatlanságot, a talajvesztettség érzését okozhatja, nem pedig felhatalmazást és énhatékonyság-érzést (Iyengar \& Lepper, 2000, id. Baumrind és munkatársai, 2010). 
Az elhanyagoló nevelói stílusú szülő elutasító, a viselkedéskontrollja laza (Baumrind, 2013), gyakran kényszerítő módszereket alkalmaz és hiányzik a gyermekre való odafigyelés (Baumrind, 1989). Minden helyzetben úgy viselkedik, hogy minimalizálja a szülőségbe fektetett időt és energiát, ellenségesen, vagy sehogyan sem válaszol, és összességében elhanyagolja a gyermek igényeit (Maccoby \& Martin, 1983). Ennek a nevelési stílusnak súlyos következményei vannak a gyermek fejlődését tekintve: alacsony önértékeléssel, kompetenciahiánnyal és serdülőkori devianciákkal kell számolni (Pulkkinen, 1982, id. Sallay \& Münnich, 1999). A szülői kontroll szükségességére hívják fel a figyelmet a gyermek nemkívánatos cselekedetei esetén azok a kutatási eredmények, ahol a szülői magatartási kontrollról kiderült, hogy javítja a magatartászavarral küzdő gyermekek pszichoszociális alkalmazkodását (Eyberg, Nelson, \& Boggs, 2008), és csökkentik az átlagosan fejlődő gyermekek antiszociális viselkedését (Barber, 1996; Barber és munkatársai, 2005).

\subsection{A szülői nevelői stílus mérési lehetőségei}

Az érdeklődés a szülók gyermeknevelési módszerei, illetve eljárásai iránt az 1950-es években kezdődött és a mai napig népszerú vizsgálati területnek számít (Vajda \& Kósa, 2005). A vizsgálatok kezdetben a gyermekek és a szülő-gyermek interakciók megfigyelésével, majd a szülők és gyermekek megkérdezésével történtek interjúk segítségével. A szülő-gyermek viselkedéseket Q-rendezéssel osztályozták (Baumrind, 1971; Block, Block, \& Morrison, 1981). Ezek az eljárások azonban túl költségesnek bizonyultak, sok idő- és energiaráfordítást igényelnek, a megfigyelők beszámolóinak megbízhatósága is kérdéses, illetve a kevés résztvevő miatt e vizsgálatok nem tekinthetők reprezentatívnak, így meglehetősen limitált következtetések levonására alkalmasak.

A gyakorlati igény szülte a vizsgálati módszerek másik csoportját: a kevésbé időigényes, s ezáltal a kutatók számára praktikusabbnak bizonyuló szülői attitúdmérő skálák kidolgozását. Velük kapcsolatban is felmerült több kérdés és probléma. Például, hogy az attitúdskálák egyáltalán mennyiben határozzák meg a tényleges viselkedést, hiszen a szülói viselkedésben fejeződik ki a szülő mögöttes attitúdje, érték- és hiedelemrendszere, s mint ismeretes, nem hagyható figyelmen kívül a szülői attribúciók szerepe sem a gyermek szocializációjában (Dix \& Grusec, 1985). Ugyanakkor az is felmerül, hogy vajon nem fektetnek-e túl nagy hangsúlyt a szülői beállítódásra (Holden, 1995, id. Cole \& Cole, 2006), hiszen a nevelői stílust nemcsak a szülők elvei befolyásolják, hanem akár ugyanolyan szinten a gyermek jellemzői is (Caspi, 1998, id. Cole \& Cole, 2006), öröklött vonásai, tempera- 
mentuma és neme (McBride, Schoppe, \& Rane, 2002; Planalp \& Goldsmith, 2019). Talán érzékelhető, hogy a kutatók számára továbbra is komoly kihívást jelent megoldást találni ezekre a problémákra.

Az alábbiakban egy rövid áttekintést adunk azokról a mérőeszközökről, amelyek legalább érintőlegesen szerepet játszottak a Parenting Styles and Dimensions Questionnaire (PSDQ; Robinson és mtsai, 2001) létrejöttében.

Az első szülői attitúdöt mérő skálák egyikét, a Parental Attitude Research Instrument (PARI) elnevezésú kérdőívet Schaefer és Bell (1958) dolgozták ki, amelynek validitásával kapcsolatban ugyan merültek fel kérdések, de több hazai kutatásban is használták már, és elfogadható eszköznek számít az attitúdök mérésére. Koncepciója, hogy különböző bipoláris dimenziók - autonómia vs. kontroll és szeretet vs. gyúlölet - mentén ragadja meg a szülői nevelői stílusokat, a későbbi mérőeszközök kidolgozóit is inspirálta. Egy másik, korai mérőeszköz a Block (1965, id. Kimble, 2014) által létrehozott Child Rearing Practices Report (CRPR), amit Dekovic, Janssens és Gerris (1991, id. Sallay \& Münnich, 1999) holland mintán, a korlátozás és gondoskodás dimenzióit mérő Likert-típusú skálává alakítottak át. Block (1965, id. Kimble, 2014) munkáját követően a szülői nevelői stílusok konceptualizálása jelentős változáson ment át, a CRPR mégis alapjául szolgált újabb mérőeszközök kialakításának. Így a Robinson, Mandleco, Olsen és Hart (1995) által megalkotott Parenting Practices Questionnaire (PPQ) - egy 62 tételes kérdőív - is nagyban támaszkodott Block (1965) munkájára. A kidolgozás során 133 tételt hoztak létre, ebból 80 tételt a CRPR-ból választottak ki, majd 53 új tétellel egészítették ki, amiket szakirodalom alapján az autoritatív, autoriter és permisszív stílusok konceptualizálásával nyertek. Egy sor faktoranalitikus elemzést követóen 62 tételt tartottak meg: 19-et (31\%) a Block-féle kérdóívbőll, 43-at (69\%) az új tételekből. Az azonosított tekintélyelvú, engedékeny és irányító stílusokon belül számos változóra, mint alskálára fókuszáltak. Az autoritatív/irányító stílus a melegség, érvelés, demokratikus részvétel, jó természetú alskálák; míg az autoritariánus/tekintélyelvú stílus az ellenségesség, testi fenyítés, büntető stratégiák, irányítás faktorokból; végül a permisszív/engedékeny stílus az alacsony önbizalom, a neveletlenség figyelmen kívül hagyása és a következetesség hiánya alskálákból tevődtek össze (Robinson és mtsai, 1995). Napjainkra számos változatát hozták létre a PPQ kérdőívnek, ezek egyike a PSDQ, amit Robinson és munkatársai (2001) a PPQ ${ }^{1}$ rövidített, 32 tételes változataként ismertettek.

\footnotetext{
1 Munkánkban az egyértelmúség kedvéért mi is a PPQ elnevezést fogjuk használni a 62 tételes változat jelölésére és PSDQ-t a 32 tételes, rövidített változatra, eltekintve az idézett szerző által használt megnevezéstől. Amennyiben a tételek eltérnek, minden esetben a tételszám megjelölésével jelezzük, hogy melyik változatról van szó.
} 


\subsection{A Szülői Nevelői Stílus Kérdőív (Parenting Styles and Dimensions Questionnaire, PSDQ) kialakítása és pszichometriai jellemzői}

A 32 tételes PSDQ kérdőívet 2001-ben Robinson és munkatársai a Parenting Styles and Dimensions Questionnaire (PSDQ - Short Version) elnevezéssel jelentették meg. A korábbi, 62 tételes PPQ kérdőívnek (Robinson és mtsai, 1995) az egyes nevelési stílusokhoz tartozó tételszámait nagyban redukálták, s ezáltal bizonyos dimenziókat ki is vettek. Az 1377 fős mintán nyert adatok faktoranalitikus elemzésével továbbra is a korábbi 3 nevelói stílust azonosították. A tekintélyelvú és az irányító stílusokat több dimenzió (alskála) segítségével írták le, míg az engedékenység stílus csak egy dimenzióból áll. Az egyes alskálákhoz (változókhoz) különböző számú tétel tartozik (ld. 1. táblázat), és a skálaképzés során ezek átlagértékét kell figyelembe venni.

A kérdőív kitöltése egyszerú, az utasítása világos: „Alább olyan szülooi viselkedések listáját találja, amelyek szülő-gyermek kapcsolatokban fordulhatnak elö. A kérdéseket annak felmérésére tervezték, hogy milyen gyakran alkalmaz Ön bizonyos viselkedésformákat a gyermekével szemben. Kérem, minden kérdésre válaszoljon!" Ugyanez az instrukció abban az esetben is, ha a kérdéseket arra vonatkoztatjuk, hogy milyennek észleli valaki a párját. Így az észlelt énre (Self) és a másikra (Other) egyaránt kaphatunk válaszokat. A válaszlehetóségeket 1-5-ig terjedő Likert-típusú skálán lehet bejelölni, az alábbi válaszlehetőségek mentén: 1 = Soha, 2 = Néha, 3 = Az esetek felében, 4 = Nagyon gyakran, 5 = Mindig. Az alskálák és skálák pontszámértékét a szerzők a releváns itemekre adott válaszok számértékének átlagával határozzák meg (Megengedő: 5 item, Tekintélyelvû: 12 item, Irányító: 15 item átlaga). Ez az eljárás például 5 item esetében 1-5 szélsőértékek között mozgó elméleti skálaterjedelmet jelent, ami további módszertani kérdéseket vethet fel, hiszen ordinális skálájú változókból számolunk átlagot.

Robinson és munkatársai (2001) az azonosítható szülői nevelői stílusok jelentését a következóképpen határozták meg:

Megengedő (permissive): Az ilyen szülők engedékenyek a gyermekükkel. Magukat nem egy ideálként állítják a gyermek elé, akivel versenyezni kell, nem is a jelenlegi vagy jövőbeni viselkedésüket formáló személyként, hanem inkább eróforrásként, amit úgy használhatnak, ahogy akarnak. Megengedik gyermeküknek, hogy amennyire csak lehet, maguk határozzák meg tevékenységüket. Távol tartják maguktól a fegyelmezés feladatát, és nem akarják gyermeküket mindenáron az átlagos viselkedés felé terelni. A megengedő szülők gyermekei kortársaikhoz képest éretlenek és önállótlanok.

Tekintélyelvü (authoritarian): Ezek a szülők a gyermekük viselkedését és attitúdjeit egy, a társadalom által elfogadott mércével akarják egyenértékú- 
1. táblázat. A Szülői Nevelői Stílus Kérdőív (PSDQ) felépítése és reliabilitási mutatói Robinson és munkatársai (2001) tanulmányában

\begin{tabular}{|c|c|c|c|c|}
\hline $\begin{array}{c}\text { Szülói nevelói } \\
\text { stílus }\end{array}$ & Változó (alfaktor) & $\begin{array}{c}\text { Mit mérnek } \\
\text { az (al)faktorok }\end{array}$ & $\begin{array}{l}\text { Tétel- } \\
\text { szám }\end{array}$ & Cronbach- $\alpha$ \\
\hline $\begin{array}{l}\text { Megengedő } \\
\text { (Permissive) }\end{array}$ & & $\begin{array}{l}\text { mennyire tartja be } \\
\text { a szülö a büntetéssel } \\
\text { kapcsolatos ígéreteit, } \\
\text { milyen mértékben } \\
\text { kényezteti el } \\
\text { gyermekét }\end{array}$ & 5 & 0,64 \\
\hline \multirow{4}{*}{$\begin{array}{l}\text { Tekintélyelvü } \\
\text { (Authoritarian) }\end{array}$} & & & 12 & 0,82 \\
\hline & $\begin{array}{l}\text { Testi fenyítés } \\
\text { (Physical Coercion } \\
\text { Dimension) }\end{array}$ & $\begin{array}{l}\text { milyen mértékben } \\
\text { hajlik a szülő a testi } \\
\text { büntetések } \\
\text { alkalmazására }\end{array}$ & 4 & \\
\hline & $\begin{array}{l}\text { Verbális ellenséges- } \\
\text { ség/szidalmazás } \\
\text { (Verbal Hostility } \\
\text { Dimension) }\end{array}$ & $\begin{array}{l}\text { milyen mértékben } \\
\text { használja a szülő } \\
\text { nevelési eszközként } \\
\text { a verbális fenyítést, } \\
\text { szidalmazást }\end{array}$ & 4 & \\
\hline & $\begin{array}{l}\text { Indokolatlan bünte- } \\
\text { tés/büntetési straté- } \\
\text { giák (Non- } \\
\text { Reasoning/Punitive } \\
\text { Dimension) }\end{array}$ & $\begin{array}{l}\text { milyen büntetési } \\
\text { eljárásokat használ, } \\
\text { és azokat miként viszi } \\
\text { véghez }\end{array}$ & 4 & \\
\hline \multirow{4}{*}{$\begin{array}{l}\text { Irányitó } \\
\text { (Authoritative) }\end{array}$} & & & 15 & 0,86 \\
\hline & $\begin{array}{l}\text { Melegség/bevonó- } \\
\text { dás (Connection } \\
\text { Dimension [Warmth } \\
\text { E Support]) }\end{array}$ & $\begin{array}{l}\text { a szülő mennyire képes } \\
\text { elfogadó, megértő, } \\
\text { együttérző légkörben } \\
\text { nevelni gyermekét }\end{array}$ & 5 & \\
\hline & $\begin{array}{l}\text { Érvelés/ } \\
\text { magyarázatok } \\
\text { (Regulation } \\
\text { Dimension } \\
\text { [Reasoning/ } \\
\text { Induction]) }\end{array}$ & $\begin{array}{l}\text { mennyire használja } \\
\text { a szülő a nevelésben } \\
\text { az érvelést, mennyire } \\
\text { tartja fontosnak } \\
\text { a következmények } \\
\text { magyarázatát } \\
\text { a nevelésben }\end{array}$ & 5 & \\
\hline & $\begin{array}{l}\text { Demokratikus rész- } \\
\text { vétel (Autonomy } \\
\text { Granting Dimension } \\
\text { [Democratic } \\
\text { Participation]) }\end{array}$ & $\begin{array}{l}\text { mennyire engedi } \\
\text { a szülő gyermeke } \\
\text { akaratát, szükségleteit, } \\
\text { kívánságait } \\
\text { érvényesülni }\end{array}$ & 5 & \\
\hline
\end{tabular}


vé tenni. Nem engedik meg a gyermeküknek az alkudozást, és kicsit sem hagyják eltérni a gyermeküket az általuk helyesnek tartott viselkedéstől. A tekintélyelvú szülők gyermekei szociálisan éretlenek, gyakran fordulnak külső tekintélyhez a problémáik megoldásáért.

Irányító (authoritative): Az ilyen szülők megpróbálják észszerú irányba terelni a gyermekük tevékenységét. Figyelembe veszik a gyermekük akaratát, érdeklődését. Döntéseikhez mindig magyarázatot is adnak. Értékelik a gyermekük meglévő értékeit, de ösztönzik is őket a további fejlődésre. Az irányító szülők gyermekei nagyobb önállóságot mutatnak, szociális interakciókban jobban feltalálják magukat, mert megszokják az ilyen helyzeteket.

\subsection{A PSDQ kérdőívvel kapott eredmények}

Olivari, Tagliabue és Confalonieri (2013) a PSDQ kérdőív egyre szélesebb körben való alkalmazhatóságát emelik ki, hiszen a megkérdezett nyilatkozhat arról, hogy szülőként hogyan neveli a gyermekét, milyennek észleli a párja/házastársa nevelési stílusát, de arról is értékes információt adhat, hogy a gyermek maga hogyan észleli a saját szüleit.

A PSDQ kérdőívet egyre több nyelvre fordították, fordítják le, különböző kultúrákban használták és használják folyamatosan. Maga Robinson és munkatársai (1996) ausztrál, orosz és kínai mintán is alkalmazták a PPQ-t, hangsúlyozva, hogy mindenhol három szülői stílus volt azonosítható, kultúrától függetlenül, apróbb eltérésekkel. A későbbiekben Kern és Jonyniene (2012) a litván adaptációját dolgozta ki a PSDQ 32 tételes kérdőívnek, a portugál verziót pedig Martins és munkatársai (2018) validálták. A török változat Önder és Gulay (2009), a spanyol dominikai és Puerto Ricó-i minta Calzada és Eyberg (2002) nevéhez köthető. Fu és munkatársai (2013) a kínai PSDQ-t validálták. A perzsa adaptációt Morowatisharifabad és munkatársai (2016) végezték Iránban. Bangladesben Arafat Yasir (2018) egy 35 tételes verziót hozott létre, magas belső reliabilitással, az autoriter, autoritatív és permisszív stílusok azonosításával (Cronbach- $\alpha$ : 0,88, 0,95 és 0,78). Kulturális összehasonlításra is alkalmazták Wu és munkatársai (2002), kínai és észak-amerikai, az Egyesült Államokban élő óvodáskorú gyermeket nevelő anyák szülói nevelői stílusát hasonlították össze. Ehhez egy kínai nevelési gyakorlatot modelláló kérdőívet használtak, és összevetették a PSDQ 26 tételes változatával. A 32 tételes változatból két nevelói stílust hoztak létre, az autoritatívot (15 tétel) és az autoritert (11 tétel). Eredményeik szerint a PSDQ mindkét kultúrában érvényes mérőeszköznek bizonyult, és alkalmas volt a kulturális különbségek feltárására, így: a kínai anyák szignifikánsan magasabb pontot értek el a testi fenyítés és alacsonyabbat a melegség/ elfogadás és demokratikus részvétel alskálákon, mint az Egyesült Államokban élő anyák. 
A gyermeki jellemzők és a szülői attitűdök közötti kapcsolatok vizsgálatánál is számos esetben találkozunk a kérdőív valamelyik változatával. A következókben ezek közül mutatunk be néhány eredményt, a teljesség igénye nélkül. Rankin Williams és munkatársai (2009) longitudinális vizsgálatban mérte az internalizáló és externalizáló viselkedés és a szülői nevelői stílus közötti összefüggéseket. A szerzők az autoritatív stílus és a csökkent internalizáló viselkedés, valamint az autoritariánus stílus és a csökkent externalizáló viselkedés között mutattak ki együttjárást. A vizsgálat keretében a szülőkkel a gyermekeik 7 éves korában töltették ki a PPQ-t, ahol az alskálák (autoritatív, autoritariánus és permisszív) magas reliabilitást, valamint 0,88, 0,77 és 0,75-ös Cronbach- $\alpha$-értékeket mutattak. Fili (2016) a gyermekek agresszív megnyilvánulásai és a szülői nevelői stílusok között kereste a kapcsolatot 310 óvodás gyermeket nevelő albán szülőnél, szintén a PPQ eredeti, 62 tételes változatát használva, és bár magas belső konzisztenciát mért az autoritatív, autoritariánus és a permisszív skálákon (Cronbach- $\alpha$ : 0,86; 0,81 és 0,71 ), érdemi kapcsolatot nem talált. Topham és munkatársai (2011) 450 anya-gyermek párost vizsgált a PSDQ-val (Cronbach- $\alpha$ : 0,84 autoritatív, 0,75 autoritariánus és 0,71 permisszív). Az eredmények szerint az a nevelői stílus, amikor a szülő minimalizálja a gyermeke negatív érzéseire adott reakcióit, a 6-8 éves gyermekek esetében szignifikáns összefüggést mutatott a gyermekek érzelmi evésre való hajlamával. Minél jellemzőbb volt az autoritatív nevelői stílus a szülőkre és gyakoribb volt családban a nyílt érzelemkifejezés, annál kisebb mértékben fordult elő a gyermekek körében az érzelmi evés.

A mérőeszköz különféle változatait idősebb gyermekeknél és fiataloknál is eredményesen alkalmazták. Például Tagliabue, Olivari, Bacchini, Affuso és Confalonieri (2014) 1451 fős olasz kamaszokból álló mintán a PPQ-nak egy 40 tételes változatát találta a legstabilabbnak, ahol az autoriter (Cronbach- $\alpha$ : 0,94 anyára, 0,95 apára), autoritatív (Cronbach- $\alpha$ : 0,96 anyára, apára) és permisszív (Cronbach- $\alpha$ : 0,62 anyára, 0,63 apára) faktorok elfogadható reliabilitását igazolta, a permisszív stílust azonban csak 4 tétel mérte. Egy évvel később, kamaszoknál - 479 fős mintán - a fiatal kommunikációja és a szülő nevelői stílusáról őrzött emlékének kapcsolatát vizsgálva, Tagliabue és munkatársai (2015) arra a következtetésre jutottak, hogy a magas elvárás és magas elfogadás egyaránt szükséges ahhoz, hogy a serdülő képes legyen a nyitott kommunikációra. Ebben a kutatásban az autoriter és autoritatív stílusokra magas reliabilitást mértek az apákra és az anyákra nézve egyaránt (a Cronbach- $\alpha$ értéke 0,86 és 0,94 között mozgott), míg a (4 tétellel mért) permisszív stílusnál a Cronbach- $\alpha$ értéke 0,47 és 0,51 volt. A kamaszok médiahasználati szokásait figyelő szülői magatartás és nevelői stílus modellálására vállalkoztak Padilla-Walker és Coyne (2011), 478 család bevonásával (európai-amerikai az apák 87\%-a, az anyák 75\%-a, a gyerme- 
kek 69\%-a; afro-amerikai az apák 6\%-a, az anyák 15\%-a, a gyermekek $13 \%$-a, és kevert etnicitású az apák $8 \%$-a, az anyák $11 \%$-a, a gyermekek $18 \%$-a). A PSDQ-t használva utánkövetéses vizsgálatukban a kapcsolódás (connection), szabályozás (regulation) és autonómia (authonomy) skálákon szintén magas reliabilitást mértek (a Cronbach- $\alpha$ értéke 0,75 és 0,84 között mozgott). A proaktív médiafigyelő stratégiákat az autoritatív nevelői stílusból tudták szignifikánsan előre jelezni, mindkét szülő esetében. Proaktív médiafigyelő stratégia például a korlátozó mediáció (,cocooning”), amely magában foglalja a szülői erőfeszítéseket az otthoni médiahasználat korlátozására; vagy az aktív mediáció („prearming”), amely stratégia alkalmazása ösztönzi a szülő és a gyermek közötti beszélgetést az adott médiatartalomnak való kitettség esetén. A szerző́k nem tekintették proaktív stratégiának az együttnézést, ahol a szülók a gyermekükkel együtt tekintik a médiát.

Mint érzékeltettük, a PSDQ-t (természetesen a PPQ-t is) kialakítása óta számos, változatos kulturális hátterú és meglehetôsen nagy létszámú mintán alkalmazták, s ez által a limitációi is egyre tisztábban látszanak. Legfontosabb korlátja, hogy csak 3 stílus azonosítására alkalmas, az „elhanyagoló" szülői nevelói attitúdöt nem méri. A másik nehézség, hogy a skálák belső reliabilitása igen változó: a Cronbach- $\alpha$ értékek a permisszív skála esetében gyakran alacsonyabbak az elvártnál. Például Martins és munkatársai (2018) 0,41-es; Önder és Gulay (2009) 0,38-as Cronbach- $\alpha$-t mértek, Olivari és munkatársai (2013) pedig áttekintó tanulmányukban 0,38 és 0,84 közötti értékekról számoltak be. Az alacsony belső konzisztenciát néhány kutató a permisszív skála alacsony tételszámával magyarázza (Martins és munkatársai, 2018), míg mások azt feltételezik, hogy ez a skála valójában az inkonzisztencia indikátora, és nem is az engedékenységet méri (Rankin Williams és munkatársai, 2009).

\section{Vizsgálatunk célja}

Vizsgálatunkban a nemzetközi szakirodalomban gyakran használt szülői nevelői stílust mérő 32 tételes kérdőív, a Parenting Styles and Dimensions Questionnaire (PSDQ) magyar mintán történó kipróbálására teszünk kísérletet, és annak a feltérképezésére, hogy a szülői nevelői stílusok milyen egyéni pszichoszociális és demográfiai jellemzőkkel, illetve a család mint rendszer szempontjából is fontos tényezőkkel járhatnak együtt. Így a szülői alrendszer szempontjából lényegesnek tartjuk, hogy a PSDQ nemcsak a saját nevelői stílusára kérdez rá a szülőnek, hanem annak a percepciójára is, ahogy ő a párját szülői minőségében észleli. A párkapcsolat észlelésének a vizsgálatára is kitérünk, egyrészt a párkapcsolati intimitást, másrészt a pár- 
kapcsolati elégedettséget tartva szem előtt. Fontosnak tartjuk megismerni a szülő felnőtt kötődéseinek összefüggését a szülői nevelői stílusával, olyan egyéni, a mentális jóllétét meghatározó jellemzők mellett, mint amilyen a szülő vonásszorongása, depresszióra való hajlama, általános egészségi állapota és társas támogatottsága.

Vizsgálatunkban a szülői oldal van a fókuszban, hiszen azokat a tényezőket vesszük górcső alá, amelyek erőteljes hatást gyakorolhatnak a szülőkre, szerepet játszva a gyermekhez való viszonyulásukban, feltételezésünk szerint befolyásolva a nevelői stílusukat is.

Az alábbiakban röviden ismertetjük azokat a kutatási eredményeket, amelyek hozzájárultak kérdéseink, illetve feltételezéseink megfogalmazásához.

A párkapcsolat minőségét olyan befolyásoló tényezőnek tartjuk, amely korábbi kutatások eredményei szerint is hatást gyakorol a gyermek jóllétére. Az általunk áttekintett vizsgálati eredmények szerint az olyan párkapcsolati konfliktusok, ahol a szülők ellenséges érzései és elégtelen konfliktusmegoldó stratégiái nyilvánulnak meg, negatívan hatnak a gyermek jóllétére (O'Leary \& Vidair, 2005), egészségére és kortárskapcsolataira (Gottman \& Katz, 1989) egyaránt. Katz és Gottman (1996) úgy vélik, hogy a problémás párkapcsolatával elfoglalt szülő visszahúzódik a gyermektől, „nincs kognitív tere" a gyermekre, például nem ismeri a barátai nevét, elfelejti a programjait, érzelmileg is elérhetetlen a számára, érdektelenül viszonyul. O’Brian és Peyton (2002) longitudinális vizsgálatukban megállapították, hogy minél alacsonyabb volt eredetileg a pár intimitása, annál nehezebbnek, problematikusabbnak észlelték a gyermeknevelést az első három évben. Cox, Paley és Harter (2001) részletesen ismertetik azokat a kutatási eredményeket, amelyek a szülők párkapcsolatának a szülő-gyermek kapcsolatra gyakorolt hatását vizsgálták, kiemelve, hogy a párkapcsolati konfliktusok gyakran átterjednek a szülőségre (ún. „sspill over teória”), míg a "kompenzációs hipotézis" szerint olyan is előfordul, hogy a párkapcsolati feszültségek miatt a szülő a gyermekkel való kapcsolatra fókuszál és abban keresi az érzelmi kielégülést. Az észleletek nagyon fontos meghatározói a párkapcsolatoknak. Egy példát kiemelve, Murray és munkatársai (2005) a pár észleletét találták a kapcsolati biztonság meghatározójának. A kapcsolattal való elégedettségról pedig megállapították, hogy nem a tényleges viselkedésen, hanem a pár szubjektív, érzelmi hatásoktól sem mentes megélésén múlik (Murray, Holmes, \& Griffin, 1996). Cohen és munkatársai (2012) azt találták, hogy a kapcsolattal való elégedettség szempontjából az empátiára való törekvés észlelete a döntő, nem pedig az empatikus pontosság: vagyis nem az, hogy ténylegesen mennyire pontosan tudott következtetni egy interakció során a partnere érzéseire, gondolataira, hanem hogy a párja 
úgy észleli, hogy törekszik empatikusnak lenni. Konkrétan a szülői nevelői stílus és a párkapcsolat összefüggéseiról kevés kutatási eredmény áll a rendelkezésünkre. O'Leary és Vidair (2005) hangsúlyozzák, hogy az anya és apa nevelői stílusa gyakran különbözhet, ami konfliktust generálhat a pár között. Tavassolie, Dudding, Madigan, Thorvardarson és Winsler (2016) az anyák és apák nevelői stílusa között hasonlóságot mutattak ki, az autoritariánus és permisszív stílusok a gyermekek megnövekedett internalizáló és externalizáló viselkedési problémáival jártak együtt, miközben a párkapcsolati konfliktusok szignifikáns kapcsolatot mutattak a gyermekek viselkedési problémáival. Ha a szülők nevelői stílusa eltért, a konfliktusok száma megnövekedett. Minél nagyobb volt a különbség a saját és a házastárs észlelt engedékenysége között, annál több externalizáló viselkedési problémát tapasztaltak a gyermek részéról. Akkor volt a legterheltebb a gyermeki viselkedés és konfliktuózusabb a párkapcsolat, mikor az anya magát irányítóbbnak látta, mint az apát, az apák tekintélyelvúbbek voltak, mint az anyák. Kedvezóbb volt azonban a helyzet, ha az apák magukat engedékenyebbnek észlelték, mint az anyák, és az anyák tekintélyelvúbbek voltak, mint az apák.

A felnőtt kötődés és a szülői nevelői stílus kapcsolata kevéssé vizsgált terület. Millings, Walsh, Hepper és O’Brien (2012) eredményei szerint a párkapcsolati szorongás és elkerülés negatív együttjárást mutat a partnerről való válaszkész gondoskodással, ez utóbbi pozitívan korrelál az autoritatív és negatívan az autoriter és permisszív nevelői stílusokkal. A szerzők a gondoskodást mediátor tényezőnek tekintik a felnőtt kötődés és a szülői nevelői stílus között. Nanu és Nijloveanu (2015) román mintán mutattak ki szignifikáns együttjárást a felnőtt párkapcsolati kötődés és az autoritatív szülői nevelői stílus között.

Jelen kutatásban a párkapcsolat minőségét a kapcsolattal való elégedettség megítélésével, a párkapcsolati intimitásban észlelt gondoskodással, kontrollal és a párkapcsolati kötődéssel kívánjuk mérni.

A szülő érzelmi stabilitását befolyásolja a saját szüleivel való kötődése. Adam, Gunnar és Tanaka (2004) a felnőtt kötődési interjúval vizsgált kétéves gyermeket nevelő anyákat, ahol az anya kötődési stílusa és szülői magatartása közötti kapcsolatot az anyai érzelmi állapot közvetítette. Az elhanyagoló stílusú anyák szignifikánsan kevesebb pozitív érzelemról számoltak be, és közülük, akik több tünetet, magasabb depressziópontot értek el, kevesebb melegséget és alacsonyabb válaszkészséget mutattak a gyermekeik felé. Az elárasztottak több negatív érzelmet, szorongást fejeztek ki, és gyermekeik felé is több dühös, erőszakos magatartást tanúsítottak. Így az anyához és apához való kötődés és a szülői nevelői stílus között is várunk összefüggéseket. 
A szülő mentális állapotát a vonásszorongás és depresszióra való hajlam mérésével próbáljuk megragadni. Mára jelentős mennyiségú szakirodalom áll rendelkezésre, amelyek eredményei szerint a szülő mentális problémái, depressziója komoly befolyással bír a szülői viselkedésre, és problémát, rizikótényezőt jelent a gyermeki fejlődésre. A tanulmányunk keretében ezekból emeltünk ki néhányat. Az anyai depresszió szoros együttjárást mutat az elhanyagolással, pszichológiai agresszióval, fizikai támadással és tettlegességgel (Turney, 2011). A depressziós anyák kevésbé empatikusak, érzelmi válaszkészségük a gyermekük felé alacsonyabb, továbbá kevesebb pozitív, és több negatív megnyilvánulást mutatnak a gyermekük felé (Feng, Shaw, Skuban, \& Lane, 2007; Lovejoy, Graczyk, O'Hare, \& Neuman, 2000). Például a kamasz depressziós anyák kevésbé kapcsolódtak, több autoritariánus viselkedést mutattak totyogó gyermekeikkel kapcsolatban, mint a nem depressziós társaik (Pelaez, Field, Pickens, \& Hart, 2008). Vera, Granero és Ezpeleta (2012) eredményei szerint az anyai és apai pszichopatológia pozitívan függ össze a gyermek antiszociális viselkedésével, viszont csak az apáknál találták a nevelói stílust kizárólagos mediátor tényezőnek.

A társas támaszt kiemelten kezeljük, mivel jelentős hatást gyakorol az egyén jóllétére (Ownsworth, Henderson, \& Chambers, 2010), életminőségére (Song \& mtsai, 2011), valamint mentális egészségére (Pons-Salvador, Cerezo, \& Trenado, 2014). Racine, Plamondon, Hentgesa, Toughd és Madigan (2019) longitudinális vizsgálatában a pártól és családtól kapott társas támogatás erőteljes védőfaktornak bizonyult, csökkentve az anyák várandósság alatti és szülés után egy évvel - összesen 4 alkalommal - mért stressz- és szorongásszintjét. Sót a társadalmi beágyazottságból jobban bejósolható a mortalitás, mint az életmódhoz kapcsolódó különböző egészségkárosító viselkedésekből, szokásból (Holt-Lunstad \& Smith, 2012). Lavasani, Borhanzadeh, Afzali és Hejazi (2011) középiskolás lányoknál a tekintélyelvú és megengedő nevelói stílusok szignifikáns negatív együttjárását mutatta ki a pszichológiai jólléttel, a társas támasz pedig pozitívan korrelált a jólléttel. Az irányító stílus nem bizonyult prediktív erejúnek, amit a szerzők az iráni minta kulturális sajátosságaival magyaráztak. Internetfüggőséggel diagnosztizált fiatalok esetében az észlelt társas támogatás alacsony volta, a szülők érzelmi elérhetetlensége, a szülői elfogadás, bevonódás, az ellenőrzés inadekvát volta, az alacsony mértékú szülői szigor és felügyelet volt jellemző (Karaer \& Akdemir, 2019). Tapasztalataink szerint a közölt kutatások az észlelt társas támaszt a gyermek fejlődése szempontjából tárgyalják, és nem a szülő támogatottságát vizsgálják, felmérve annak esetleges kihatásait a nevelói stílusra.

A fent áttekintett szakirodalmi eredmények alapján a feltáró jellegú vizsgálatunk keretében három vizsgálati kérdés megválaszolására vállalkozunk. 
1. Mely szociodemográfiai tényezők játszhatnak szerepet a szülői nevelői stílus alakulásában?

2. Milyen összefüggéseket mutat a párkapcsolat minőségének észlelése és a saját, valamint a pár nevelói stílusának észlelése?

3. Mutat-e összefüggést a szülő mentális jólléte és társas támogatottsága a saját és a pár szülői nevelői stílusának észleletével?

Fontos kiemelnünk, hogy Baumrind és munkatársai (2010) az irányító nevelói stílust tekintették optimálisnak a gyermek fejlódése szempontjából. Mi elfogadjuk ezt a megállapítást, annak ellenére, hogy bizonyos vizsgálatok eredményei felhívják a figyelmet a kulturális különbségekre (ld. Wu és mtsai, 2002), hiszen a magyar kultúrához leginkább az angolszász kultúra áll közel. Így elemzéseink során az irányító stílust tartjuk optimálisnak, míg a megengedő és tekintélyelvú stílusokat kevésbé hatékonynak. Amikor irányító és tekintélyelvú stílusról beszélünk, akkor az adott stílushoz tartozó alskálákat vesszük figyelembe. A fent tárgyalt szakirodalom eredményei alapján a jelen vizsgálat keretében az alábbi hipotéziseket kívánjuk tesztelni.

a) A párkapcsolati intimitásban az észlelt gondoskodás az irányító szülői nevelői stílus észlelésével jár együtt, míg az észlelt kontroll a megengedő és a tekintélyelvú stílusokkal korrelál pozitív irányban.

b) A párkapcsolati elégedettség az irányító szülői nevelői stílus fokozottabb jelenlétének észlelésével jár együtt.

c) A párkapcsolati kötődés biztonságának növekedése az irányító szülői nevelői stílus észlelésével jár együtt, azaz a kapcsolati szorongás és elkerülés negatívan korrelál az irányító, míg pozitívan korrelál a megengedó és a tekintélyelvú stílusokkal.

d) A felnőtt kötődés biztonsága a szülőkkel az irányító szülői nevelői stílus észlelésével jár együtt, azaz a kapcsolati szorongás és elkerülés negatívan korrelál az irányító, míg pozitívan korrelál a megengedő és a tekintélyelvú stílusokkal.

e) A szülő vonásszorongása és depresszióra való hajlama egyaránt negatív irányú együttjárást mutat az irányító nevelói stílussal.

A társas támogatás észlelése és az irányító nevelői stílus pozitív irányú együttjárást mutat.

Úgy véljük, hogy eredményeink a szülői nevelői stílusnak egy tágabb kontextusba való helyezésével segíthetik azt a pszichoedukatív munkát, amellyel a szülők, családok támogathatóak a gyermeknevelésben. 


\section{Módszer}

\subsection{Minta és eljárás}

A keresztmetszeti, kérdőíves vizsgálatot a Károli Gáspár Református Egyetem Pszichológiai Intézetének Etikai Bizottsága jóváhagyta (az etikai engedély száma: 53/2018/P), a Fejlódéslélektani Tanszéken folyó szocializáció, pár- és családi interakció-dinamika kutatás részeként.

A reprezentativitásra való törekvés érdekében falvakban, vidéki városokban és a fővárosban élő anyákat és apákat egyaránt bevontunk a kutatásba. A mintába való bekerülésnél fontos szempont volt a nagykorúság (az alsó korhatár a 18 év, felső korhatár nem volt meghatározva). Kizárási kritérium volt az analfabetizmus és a gyermektelenség. Az adatgyújtés a Károli Gáspár Református Egyetem pszichológia szakos hallgatóinak segítségével, elektronikus úton, informált hozzájárulással, önkéntes és anonim módon, hólabda módszerrel történt, 2018. február 20. és 2019. február 11. között.

A PSDQ kérdőív magyar adaptációját dr. Robinson Clyde engedélyezte. A kérdőív angolról magyarra történő, majd angol nyelvre való visszafordítása két lépésben zajlott. Az Önmagára (Self) vonatkozó állításokat Kiss Nóra (2008), a Másikra (Other) vonatkozó tételek fordítását dr. Hadházi Éva végezte, szakfordító bevonásával. A végső változat kialakítása során összevetettük az eredeti angol és a magyarról angolra visszafordított változatot, majd megtettük a szükséges módosításokat, így született meg a végleges magyar nyelvú változat.

A mintába 711 fó (113 férfi és 598 nő) adatai kerültek. A nemi eltolódás igen jelentős a nók javára, ami a vizsgálat online lebonyolításának a sajátosságából is fakadhat: a férfiak kevésbé vállalták a meglehetősen hosszú időt (kb. 40 percet) igénybe vevő kérdőívcsomag kitöltését, a munka honorálására pedig nem volt lehetőség, ami esetleg növelhette volna a részvételi motivációt. Így, bár az eltolódás nagyobbnak hat, G-Power elemzéssel, ${ }^{2}$ közepes hatásméret feltételezésével, 5\%-os szignifikanciaszint, illetve 5\%-os statisztikai erő (másodfajú hiba) mellett meghatároztuk a minimálisan szükséges esetszámot, amely 400 fós mintaelemszámot eredményezett. Ez azt jelenti, hogy közepes hatásmértékeket alapul véve a minimális esetszámot messze meghaladó mintanagysággal rendelkezünk, így nem tartottuk szükségesnek további alminták létrehozását, illetve az esetleges utólagos súlyozásokat.

A résztvevők életkorának átlaga $34,8(S D=10,91)$ év volt. A legfiatalabb kitöltő 18, a legidősebb 74 éves volt. A gyermekszám átlaga 1,98 (SD = 1,04) volt, a gyermekek átlagéletkora pedig 9,71 év $(S D=7,78)$ év. A demográfiai adatokat a 2. táblázatban mutatjuk be.

2 http://www.gpower.hhu.de/ 
2. táblázat. A vizsgálati minta demográfiai jellemzőinek összefoglaló táblázata

\begin{tabular}{|c|c|c|c|c|c|}
\hline \multicolumn{3}{|c|}{ Demográfiai adatok } & $n$ & $\%$ & Valid \\
\hline \multirow[t]{2}{*}{ Nem } & \multicolumn{2}{|l|}{ férfi } & 113 & 15,9 & 15,9 \\
\hline & \multicolumn{2}{|l|}{ nő } & 598 & 84,1 & 84,1 \\
\hline \multirow[t]{4}{*}{ Jövedelem } & \multicolumn{2}{|l|}{ átlag alatti } & 73 & 10,3 & 10,3 \\
\hline & \multicolumn{2}{|l|}{ átlagos } & 285 & 40,1 & 40,1 \\
\hline & \multicolumn{2}{|l|}{ kissé az átlag feletti } & 246 & 34,6 & 34,6 \\
\hline & \multicolumn{2}{|l|}{ átlag feletti } & 107 & 15,0 & 15,0 \\
\hline \multirow{5}{*}{$\begin{array}{l}\text { Iskolai } \\
\text { végzettség }\end{array}$} & \multirow{2}{*}{$\begin{array}{l}\text { érettségivel nem } \\
\text { rendelkező }\end{array}$} & általános iskola & 3 & 0,4 & 0,4 \\
\hline & & szakmunkásképző & 22 & 3,1 & 3,1 \\
\hline & \multirow[t]{2}{*}{ érettségivel rendelkező } & $\begin{array}{l}\text { szakközépiskola, } \\
\text { gimnázium }\end{array}$ & 157 & 22,1 & 22,1 \\
\hline & & $\begin{array}{l}\text { főiskolai, egyetemi } \\
\text { hallgató }\end{array}$ & 39 & 5,5 & 5,5 \\
\hline & felsőfokú végzettségú & fóiskola, egyetem & 490 & 68,9 & 68,9 \\
\hline \multirow{4}{*}{$\begin{array}{l}\text { Családi } \\
\text { állapot }\end{array}$} & \multicolumn{2}{|l|}{ házas } & 526 & 74,0 & 74,0 \\
\hline & \multicolumn{2}{|l|}{ élettársi kapcsolat } & 128 & 18,0 & 18,0 \\
\hline & \multirow[t]{2}{*}{ egyéb } & elvált & 38 & 5,3 & 5,3 \\
\hline & & egyedül élő & 19 & 2,6 & 2,6 \\
\hline \multirow[t]{4}{*}{ Egzisztencia } & \multicolumn{2}{|l|}{ egyedül biztosítom } & 73 & 10,3 & 10,3 \\
\hline & \multicolumn{2}{|l|}{ nagyban hozzájárulok } & 285 & 40,1 & 40,1 \\
\hline & \multicolumn{2}{|c|}{ párommal azonos arányban } & 246 & 34,6 & 34,6 \\
\hline & \multicolumn{2}{|c|}{ nem számottevő arányban járulok hozzá } & 107 & 15 & 15 \\
\hline \multirow[t]{3}{*}{ Lakóhely } & \multicolumn{2}{|l|}{ főváros } & 300 & 42,2 & 42,2 \\
\hline & \multicolumn{2}{|l|}{ város } & 309 & 43,5 & 43,5 \\
\hline & \multicolumn{2}{|l|}{ község/ falu } & 112 & 14,3 & 14,3 \\
\hline \multirow{2}{*}{$\begin{array}{l}\text { Krónikus } \\
\text { betegség }\end{array}$} & \multicolumn{2}{|l|}{ nincs } & 591 & 83,1 & 83,1 \\
\hline & \multicolumn{2}{|l|}{ van } & 120 & 16,9 & 16,9 \\
\hline \multirow{4}{*}{$\begin{array}{l}\text { Mentális } \\
\text { betegség } \\
\text { miatti kezelés }\end{array}$} & \multicolumn{2}{|l|}{ nem állt kezelés alatt } & 560 & 78,8 & 78,8 \\
\hline & \multicolumn{2}{|l|}{ gyógyszeres kezelés } & 19 & 2,7 & 2,7 \\
\hline & \multicolumn{2}{|l|}{ pszichoterápia } & 95 & 13,4 & 13,4 \\
\hline & gyógyszeres és pszichot & rápia & 37 & 5,2 & 5,2 \\
\hline
\end{tabular}




\subsection{Eszközök}

Vizsgálatunk során az összefüggések feltárásához több kérdőívet is alkalmaztunk, valamint számos szociodemográfiai adatot rögzítettünk (ld. 2. táblázat). Így a nem, jövedelem, iskolázottság, családi állapot, egzisztenciához való hozzájárulás, lakóhely mellett rákérdeztünk a mentális betegség meglétére, illetve a kezelés módjára (Állt-e pszichológiai kezelés alatt? Ha igen, akkor milyen kezelésben részesült: gyógyszeres, pszichoterápia, vagy mindkettó), valamint szenved-e valamilyen krónikus testi betegségben, ha igen, akkor nevezze meg a betegséget.

Az intim kötódés mérésére a Wilhelm és Parker (1988) által kidolgozott Intimate Bond Measurement (IBM) kérdőív magyar változatát, az IBM-HU-t (Hadházi \& Takács, 2019) használtuk. A méróeszköz 24 tétel segítségével ragadja meg, hogy a kitöltő személy milyennek észleli a partnere iránta tanúsított attitúdjeit és viselkedéses megnyilvánulásait, azaz milyen mértékú intimitást észlel a párja attitúdjei és viselkedése alapján. A válaszadás 4-fokú Likert-típusú skálán történik, a "tökéletesen igaz" (3), „többnyire igaz” (2), "kismértékben igaz" (1) és „egyáltalán nem igaz” (0) lehetőségek valamelyikének megjelölésével. Két skálája a „gondoskodás” és „kontroll” dimenzióit tartalmazza, egyenként 12-12 tétellel. A Gondoskodás dimenzió érzelmi és fizikai gondoskodást fejez ki, melegséget, figyelmet, vonzalmat és baráti kapcsolatot. A Kontroll dimenzió dominanciát, tolakodást, kritikát, tekintélyelvú attitúdöt és viselkedést fed. A mérőeszköz tételei egyirányúak. A kapott pontértékeket (tételenként 0-3-at), skálánként kell összegezni, és az elérhetó maximális pontszám skálánként 36. A két dimenzió mindegyike homogén és egymással negatívan korrelál. Vagyis minél inkább nó a kontroll egy intim kapcsolatban, annál inkább csökken a gondoskodás. A magyar mintán történt adaptálás során a kérdőív megbízható mérőeszköznek bizonyult, saját mintánkon is magas belső konzitenciát mutatott (Cronbach- $\alpha$ : Gondoskodás 0,954, Kontroll 0,907).

Kapcsolati Elégedettség Skála (Relationship Assessment Scale; RAS; Hendrick, Dicke, \& Hendrick, 1998): a párkapcsolati elégedettség mérésére a Martos, Sallay, Szabó, Lakatos és Tóth-Vajna (2014) által validált Kapcsolati Elégedettség Skála 8-tételes magyar változatát (RAS-H) használtuk. A kitöltő 1-től 5-ig terjedő Likert-típusú skálán értékelheti a kapcsolatának egyes jellemzőit az „egyáltalán nem” / „kevéssé igaztól” (1), a „teljes mértékben” / "nagyon jellemzőig” (5). Minél magasabb összpontszámot ér el valaki, annál elégedettebb a személyközi kapcsolatával. Számos kutatásban használták, változatos életkori, etnikai, sőt betegcsoportok esetében is. A jó pszichometriai tulajdonságai, rövidsége, érthetősége, egyszerú és gyors kitölthetősége és értelmezhetősége igen népszerúvé teszik a változatos inter- 
perszonális kapcsolatokkal való elégedettség mérésére. A kérdőív belső megbízhatósága a jelen vizsgálatban megfelelőnek bizonyult (Cronbach- $\alpha$ : $0,931)$.

A Közvetlen Kapcsolatok Élményei Kérdőív (Experiences in Close Relationships - Relationship Structures; ECR-RS; Fraley, Heffernan, Vicary, \& Brumbaugh, 2011): a mérőeszközt Jantek és Vargha (2016) adaptálta magyarra a felnőtt kötődés korszerú mérési lehetőségeként. A kérdőív 10 tételt tartalmaz, amelyek különböző felnőtt kötődési személyekre vonatkoztathatóak (apa, anya, pár, barát). Vizsgálatunkban arra kértük a személyeket, hogy az apára, az anyára, illetve a jelenlegi párjukra vonatkoztatva töltsék ki a kérdőívet, és amennyiben aktuálisan nincs párkapcsolatuk, akkor az utolsó párkapcsolatukra gondoljanak. 7-fokú Likert-típusú skálán lehet jelölni az egyetértés mértékét, ahol az 1-es azt jelenti, hogy egyáltalán nem ért egyet az állítással, vagy nem jellemző az állítás; a 7-es pedig azt jelenti, hogy teljes mértékben egyetért, vagy teljesen jellemző. Az ECR-RS jó belső megbízhatósági mutatókkal rendelkezik, a feltáró faktorelemzés az elkerülés (6 tétel) és szorongás (3 tétel) alskálákkal a kötődés kétfaktoros elképzelését támasztja alá. A két dimenzió segítségével képes azonosítani a négy kötődési típust, úgymint: biztonságos, elárasztott, elutasító és félelemteli elkerülő (Fraley, Waller, \& Brennan, 2000). A 10. tétel a magyar változatban sem sorolható be egyértelmúen egyik faktor alá sem. Jantek és Vargha (2016) a kérdőív konstruktum validitását megfelelőnek tartja: a magasabb párkapcsolati elkerülés és szorongás alacsonyabb általános jólléttel, párkapcsolati elégedettséggel és párkapcsolati megküzdési erőforrás értékekkel, valamint magasabb depresszió és párkapcsolati stressz értékekkel jár együtt. Mivel a legtöbb ember a biztonságosan kötődő típusba sorolható, biztató, hogy a bizonytalan kötődés, azaz magas elkerülés és magas szorongás esetén jobban differenciál az eszköz (Jantek \& Vargha, 2016). A kérdőív skáláinak belső megbízhatósága a jelen vizsgálatban megfelelőnek bizonyult (Cronbach- $\alpha$ : párra 0,9 [elkerülés] és 0,89 [szorongás]; anyára 0,9 [elkerülés] és 0,84 [szorongás]; apára 0,88 [elkerülés] és 0,87 [szorongás]).

Vonásszorongás skála (State-Trait Anxiety Inventory - Trait Anxiety Scale; STAI-T; Spielberger, Gorsuch, \& Lushene, 1970; magyar változat: Sipos \& Sipos, 1978): a vonásszorongást méró, 20 kérdést tartalmazó kérdőív Likerttípusú skálát használ, ahol tételenként négy lehetőség közül választva jellemezheti magát a vizsgálati személy, aszerint, hogy általában hogyan érzi magát. Az egyetértés mértéke 1-4 között pontozható az „egyáltalán nem”, „valamennyire”, „eléggé" vagy „teljesen/nagyon” válaszoknak megfelelően. A maximálisan elérhető pontszám 80 , a minél magasabb pontérték a fokozottabb vonásszorongást jelöli. A kérdőívet a széles körú gyakorlati elterjedtsége, közérthetősége miatt választottuk. Saját vizsgálatunkban a skála belső megbízhatósága megfelelőnek bizonyult (Cronbach- $\alpha$ : 0,915). 
Zung-féle Önértékelő Depresszió Skála (Self-Rating Depression Scale; Zung, 1965; magyar változat: Simon, 1988): a 20 tételból álló kérdőív 4-fokú Likerttípusú skálán méri a depresszió összes tünetét, felöleli a pszichés és fiziológiai alkotóit, a DSM-IV (1997) szimptóma legtöbb kritériumát lefedi. Jól alkalmazható a depresszió felderítésében, a depressziós betegek állapotváltozásának nyomon követésében, és a kezelés alatti szimptomatikus változások kimutatásában. Kiegészítő klinikai eszközként a diagnosztikus munkában, kutatási munkában, csoportosan és egyénileg is használják. Kvantitatív módon mér, az összpontszámot az egyes tételekhez tartozó pontszámok összege adja meg. A depresszió mértéke a következők szerint osztályozandó: 56 pont felett súlyos, 48-55 pont között közepes, 41-47 pontok között enyhének tekinthetô. Nem valószínúsíthetô depresszió 40 pontértéken, vagy alatta (Ágoston \& Szili, 2001). Kiemelendő, hogy a kérdőív nem alkalmas a depresszió diagnózisának felállítására, csupán becslóskálai támpontokat ad, így vizsgálati személyeinknél a depresszió skálán elért értékkel dolgozunk, becslésre vállalkozunk, számolva azzal, hogy 48 pont fölött nem zárható ki a depresszió. Saját mintánkon a kérdőív belső megbízhatósága megfelelőnek bizonyult (Cronbach- $\alpha$ : 0,842).

MOS Társas Támasz Kérdôív (MOS Social Support Survey; MOSS SSS; Sherbourne \& Stewart, 1991): a kérdőív magyar adaptációját Sz. Makó és munkatársai (2016) végezték. A mérőeszköz három faktor (Érzelmi-információs támasz, Pozitív szociális interakción alapuló támasz és Instrumentális támasz) segítségével, megfelelő megbízhatósággal méri a társas támogatottságot: a belső konzisztencia értékei és a teszt-reteszt reliabilitás értékei egyaránt magasak. Egy kérdés a szociális háló kiterjedtségét azonosítja, 19 pedig 5-fokú Likert-típusú skálán (a soha [1] és mindig [5] végpontok között) segít meghatározni, hogy milyen támaszfajta milyen gyakran áll az illető rendelkezésére. Az elérhető pontszámok 19 és 95 között alakulhatnak. A skálákon elért magasabb pontszám nagyobb mértékú társas támogatást jelez. A kérdőív skáláinak belsó megbízhatósága a jelen vizsgálatban megfelelőnek bizonyult (Cronbach- $\alpha$ : 0,951, 0,919 és 0,902).

Szülői Nevelői Stílus Kérdőív (Parenting Styles and Dimensions Questionnaire; PSDQ; Robinson és mtsai, 2001; ld. Függelék). A kérdőívet Önmagára (Self) és a Másikra (Other) vonatkoztatva egyaránt kitöltettük, a korábban már ismertetett szerzői ajánlások alapján, valamint iránymutatásaik szerint meghatároztuk a skálaértékeket. Az alábbiakban részletesen ismertetjük az elemzéseink eredményeit. 


\subsection{Statisztikai elemzések}

A PSDQ-HU struktúráját konfirmatív faktorelemzéssel teszteltük. Az ellenőrzéshez használt mutatók a khí-négyzet próba szabadságfokkal korrigált mutatója (3 alatt), az RMSEA és SRMR hibát méró együtthatói (0,1 alatt), illetve az illeszkedés jóságát méró TLI és CFI indexek (0,85 felett). A mutatókat (Takács, 2020) könyve alapján határoztuk meg. A kérdőívek belső megbízhatóságát Cronbach- $\alpha$ értékek kiszámolásával ellenőriztük.

A kérdőívek egymással való korrelációjakor Kendall- és Pearson-féle együtthatókat egyaránt számítottunk, de a Pearson-féle korrelációs együtthatókat ismertetjük, mert a két eredmény lényegében megegyezett (azonos irányok és nagyságrendek alakultak ki). A nagy mintára való tekintettel a szövegben csak azokat az együttjárásokat ismertetjük, ahol az összefüggés abszolút értékben legalább 0,3-as értéket elért. A korrelációk erősségének a megnevezésekor Takács (2016) ajánlását követtük. ${ }^{3}$

A hipotézisvizsgálatokat hagyományos és robusztus eljárásokkal (Welchféle varianciaanalízis [VA] és Johansen-féle interakciós tesztelés, ld. Vargha, 2015) egyaránt teszteltük. Minden esetben 0,05-ös p-értékek melletti döntéshozatalt alkalmaztunk úgy, hogy a korrigált magyarázott varianciahányadot (ómega-négyzet) is figyelemmel kísértük. Előzetesen legalább 5\%-os magyarázott varianciahányad volt az, ahol kiegészítő vizsgálatokat szándékoztunk végrehajtani (például az összefüggéseket csoportbontásokban is tesztelni). Amennyiben csak két csoport összehasonlítása történt (nemek szerinti összehasonlítás, testvérek megléte/nem megléte), úgy a varianciaanalízis helyett a kétmintás $t$-próba, illetve annak robusztus változata, a Welch-féle $d$-próba alapján hoztunk döntést a varianciaanalízis analógiáját követve. A hatásmértéket itt nem a magyarázott varianciahányad szerint, hanem Cohen-féle hatásmérték-mutató (Cohen- $d$ ) alapján értékeltük (legalább 0,2-es szintet elérve közepes, 0,7 felett erős, jelentős eltérésként értékelve a különbségeket).

A konfirmatív faktoranalízist az R programcsomag Lavaan eljárásával (Rosseel, 2012) a többi elemzést IBM SPSS 26.0, JASP. 0.14.1.0, illetve STATA15.0 programcsomagokkal folytattuk le.

3 Takács (2016) ajánlása: amennyiben a korrelációs együttható abszolútértékben 0,3 alatti értéket mutatott, akkor azt gyenge, szakmailag irreleváns kapcsolatként kezeltük, 0,3 és 0,7 között közepes erősségúnek tekintettük, 0,7 felett pedig erősnek. Miután a döntéshozatalban alapvetóen a kapcsolat erősségét tekintettük iránymutatónak, ezért a $p$-értékek ilyen irányú korrekciójára nem volt szükség (a 711 fős minta esetében a közepes mértékú korrelációknál a $p$-érték megfelelően alacsony szintú volt a több korrelációs együttható együttes számítása esetében fellépó $p$-infláció hatását is figyelembe véve). 


\section{Eredmények}

\subsection{A PSDQ-HU strukturális elemzése és belső megbízhatósága}

A Robinson és munkatársai (2001) által megállapított tételbesorolást (ld. 1. táblázat) ellenóriztük konfirmatív faktorelemzéssel. Az itemek és az elsórendú/másodrendú faktorok közötti kapcsolati struktúra leírását több felosztásban is ellenőriztük (3. táblázat). A saját/másik kérdőívrészt első esetben két külön kérdőívként (tehát külön-külön) kezelve dolgoztuk fel két külön modellben, valamint utána egyben is elemeztük (tehát a két modellt összeöntve). Ezek után ugyanezen elrendezést használtuk úgy is, hogy másodrendú faktorokat is beépítettünk a modellekbe. Minden esetben engedélyeztük az elsőrendú faktorok közötti kovarianciát - amelyet majd az 1. ábrán nem fogunk feltüntetni a jobb átláthatóság kedvéért, de az összesített skálákra nyert korrelációs együtthatókat külön táblázatban közüljük. Összesen tehát 6 modellt ellenőriztünk az alábbi formában.

1. Hét elsőrendú faktor (Saját és Másik külön-külön tesztelve, illetve egyazon modellben, megengedve a kovarianciát az elsőrendú faktorok a között).

2. Hét elsőrendú faktor, amelyek közül hat faktor két másodrendú faktorba rendeződik (Saját és Másik külön-külön tesztelve, illetve egyazon modellben, megengedve a kovarianciát az elsőrendú faktorok között).

A 3. táblázatban jól látható, hogy a kizárólag elsőrendú faktorokat tartalmazó elméleti modellek jobb illeszkedést mutatnak az adatokra, mint a másodrendú faktorokat is feltételező modellek. Az SRMR és az RMSEA értékei alacsonyabbak a megfelelő, másodrendú faktorokat tartalmazó variánsoknál, valamint a TLI és a CFI értékek egyaránt magasabbak a szintén megfelelő, másodrendú faktorokat tartalmazó alternatíváknál. Fontos azonban azt is kiemelnünk, hogy az RMSEA esetében látható konfidencia-intervallumok alapján nincsenek érdemi, szignifikáns eltérések, hiszen a konfidencia-intervallumok minden modell esetében összemetszenek.

Összességében az mondható el, hogy mindkét alternatíva során a „másik" megítélése mutatott konzisztensebb viselkedést (magasabb TLI/CFIértékek, illetve kisebb hibák).

Ha megnézzük az összes illeszkedési mutatót, akkor a $\chi^{2} /$ df értéket, minden tesztelt modell esetében 3 alatti értékeket kapunk, illetve a hibák (SRMR- és RMSEA-értékek 0,1 alattiak), valamint az illeszkedési mutatók minden esetben elmaradnak a leginkább elvárt 0,9-es értékektől. Így tehát, összegezve a 6 darab tesztelt modell mutatóit még a másodrendú faktorok alkalmazása esetén is ugyanannyira elfogadhatónak találjuk a megerősító faktorelemzések alapján, mint a másodrendú faktorokat nem tartalmazó modelleket. Így az első- és másodrendű faktorok belső konzisztenciáját 
mérő Crombach- $\alpha$ értékeket is közöljük az alább található 4. táblázatban (az ábrát STAT15.0 programcsomagban készítettük el).

3. táblázat. A Szülői Nevelői Stílus Kérdőív (PSDQ-HU)

konfirmatív faktorelemzésének eredményei

\begin{tabular}{|c|c|c|c|c|c|c|}
\hline \multicolumn{2}{|c|}{ Elméleti modell } & \multirow{2}{*}{$\begin{array}{c}\chi^{2}(\mathrm{DF}) \\
p \\
944,476 \\
(443) \\
p<0,001\end{array}$} & \multirow{2}{*}{$\begin{array}{c}\text { TLI } \\
0,796\end{array}$} & \multirow{2}{*}{$\begin{array}{l}\text { CFI } \\
0,818\end{array}$} & \multirow{2}{*}{$\begin{array}{c}\begin{array}{c}\text { RMSEA } \\
{[90 \% \mathrm{CI}]}\end{array} \\
0,059 \\
{[0,054 ; 0,064]}\end{array}$} & \multirow{2}{*}{$\begin{array}{l}\text { SRMR } \\
0,065\end{array}$} \\
\hline $\begin{array}{l}7 \text { elsőrendú } \\
\text { faktor }\end{array}$ & $\begin{array}{l}\text { Saját - Self } \\
\text { (a saját nevelői } \\
\text { stílus) }\end{array}$ & & & & & \\
\hline & $\begin{array}{l}\text { Másik - Other } \\
\text { (a szülőtárs észlelt } \\
\text { nevelői stílusa) }\end{array}$ & $\begin{array}{c}1004,629 \\
(443) \\
p<0,001\end{array}$ & 0,890 & 0,902 & $\begin{array}{c}0,063 \\
{[0,057 ; 0,068]}\end{array}$ & 0,066 \\
\hline & $\begin{array}{l}\text { Saját - Self és } \\
\text { Másik - Other } \\
\text { EGYBEN }\end{array}$ & $\begin{array}{c}4009,866 \\
(1861) \\
p<0,001\end{array}$ & 0,782 & 0,764 & $\begin{array}{c}0,060 \\
{[0,057 ; 0,062]}\end{array}$ & 0,066 \\
\hline \multirow{3}{*}{$\begin{array}{l}7 \text { elsőrendú } \\
\text { faktor két } \\
\text { másodrendú } \\
\text { faktorral }\end{array}$} & $\begin{array}{l}\text { Saját - Self } \\
\text { (a saját nevelói } \\
\text { stílus) }\end{array}$ & $\begin{array}{c}1002,019 \\
(455) \\
p<0,001\end{array}$ & 0,783 & 0,801 & $\begin{array}{c}0,061 \\
{[0,056 ; 0,066]}\end{array}$ & 0,072 \\
\hline & $\begin{array}{l}\text { Másik - Other } \\
\text { (a szülőtárs észlelt } \\
\text { nevelői stílusa) }\end{array}$ & $\begin{array}{c}1138,321 \\
(455) \\
p<0,001\end{array}$ & 0,870 & 0,881 & $\begin{array}{c}0,068 \\
{[0,063 ; 0,073]}\end{array}$ & 0,088 \\
\hline & $\begin{array}{l}\text { Saját - Self és } \\
\text { Másik - Other } \\
\text { EGYBEN }\end{array}$ & $\begin{array}{c}4453,225 \\
(1927) \\
p<0,001\end{array}$ & 0,732 & 0,774 & $\begin{array}{c}0,064 \\
{[0,061 ; 0,066]}\end{array}$ & 0,089 \\
\hline
\end{tabular}

4. táblázat. A Szülói Nevelói Stílus Kérdőív (PSDQ-HU) alskáláinak belső megbízhatósága

\begin{tabular}{|c|c|c|c|c|}
\hline \multirow{2}{*}{$\begin{array}{c}\text { Szülói } \\
\text { nevelói stílus }\end{array}$} & \multirow[t]{2}{*}{ Változó (alfaktor) } & \multirow{2}{*}{$\begin{array}{c}\text { Tételek } \\
\text { száma }\end{array}$} & \multicolumn{2}{|c|}{ Cronbach- $\alpha$} \\
\hline & & & Saját (S) & Másik (O) \\
\hline 1. Megengedö & & 5 & 0,635 & 0,728 \\
\hline \multirow[t]{4}{*}{ 2. Tekintélyelvü } & Összes Tekintélyelvú alfaktor & 12 & 0,733 & 0,884 \\
\hline & Testi fenyítés & 4 & 0,659 & 0,785 \\
\hline & $\begin{array}{l}\text { Verbális ellenségesség / } \\
\text { szidalmazás }\end{array}$ & 4 & 0,655 & 0,849 \\
\hline & $\begin{array}{l}\text { Indokolatlan büntetés / } \\
\text { büntetési stratégiák }\end{array}$ & 4 & 0,537 & 0,766 \\
\hline \multirow[t]{4}{*}{ 3. Irányító } & Összes Irányító alfaktor & 15 & 0,849 & 0,953 \\
\hline & Melegség / bevonódás & 5 & 0,735 & 0,915 \\
\hline & Érvelés / magyarázatok & 5 & 0,810 & 0,924 \\
\hline & Demokratikus részvétel & 5 & 0,696 & 0,840 \\
\hline
\end{tabular}




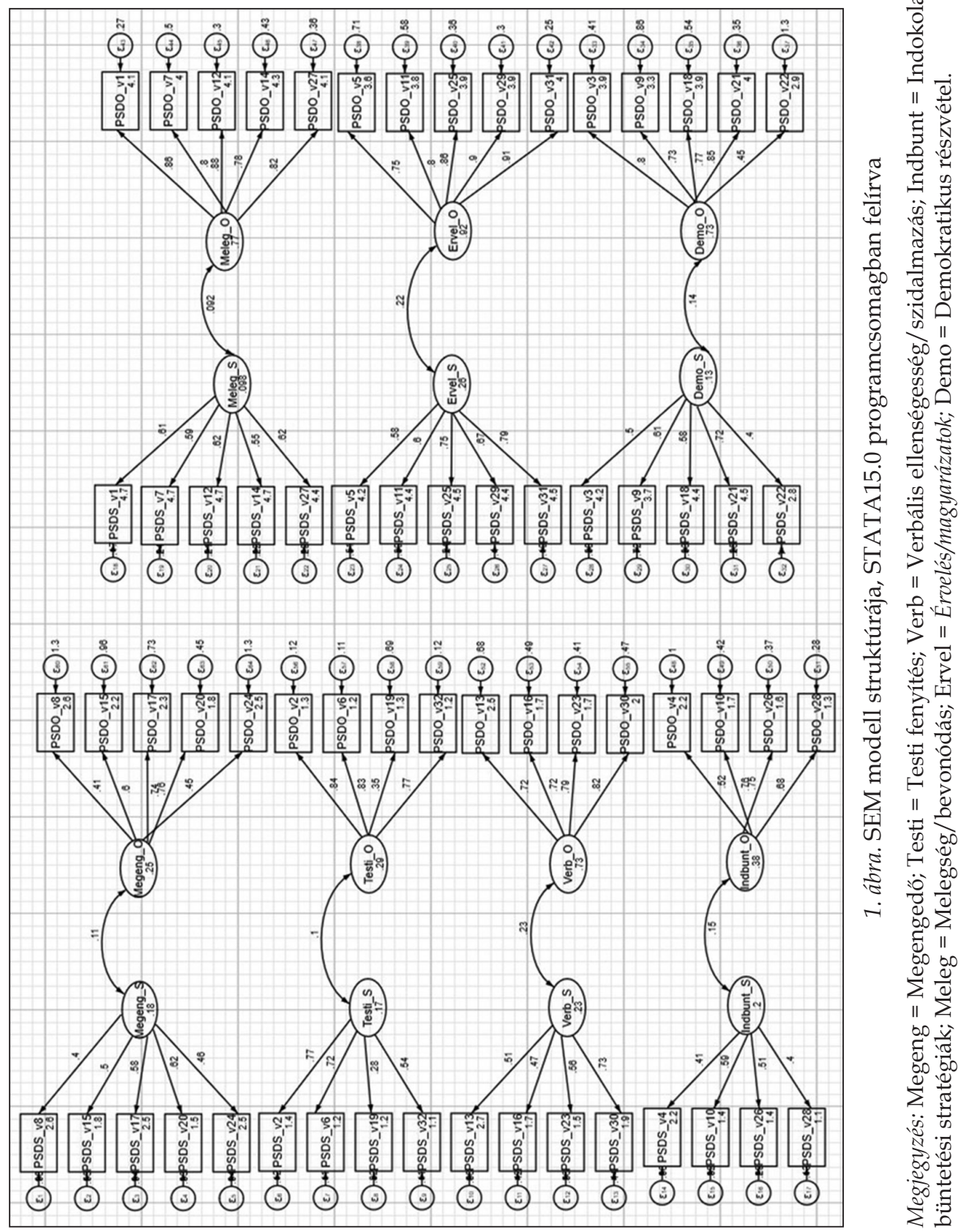


Azt azonban elmondhatjuk, hogy a két kérdőív részre (saját és másik) külön-külön kezelve sem kapunk elfogadhatatlan illeszkedést. Eredményeink alapján összességében elsősorban az alskálákkal (elsőrendú faktorok) való munkát javasoljuk.

Az alskálák Cronbach- $\alpha$ értékeit tartalmazó 4. táblázatban az összevont skálákra kiszámított értékeket is közöljük, de a finomabb elemzés érdekében a továbbiakban csak az alskálákkal fogunk érdemben foglalkozni.

Az alskálák egymással való kapcsolatát Pearson-féle korrelációval vizsgáltuk, az összefüggéseket az 5. táblázat mutatja. A Megengedő skála közepesen, pozitív irányban korrelált a Verbális ellenségesség és a párra vonatkozó Megengedő skálával. A párra vonatkozó Megengedő skála a párra vonatkozó Verbális ellenségesség és a párra vonatkozó Indokolatlan büntetés alskálákkal mutatott közepes mértékú, pozitív irányú együttjárást.

A Testi fenyítés alskála a Verbális ellenségesség, Indokolatlan büntetés és a párra vonatkozó Testi fenyítés alskálákkal közepes mértékú, pozitív korrelációt mutatott. A párra vonatkozó Testi fenyítés alskála közepesen, pozitívan korrelált a párra vonatkozó Verbális ellenségesség és a párra vonatkozó Indokolatlan büntetés alskálákkal.

A Verbális ellenségesség alskála az Indokolatlan büntetés és a párra vonatkozó Verbális ellenségesség alskálákkal pozitív, közepes mértékú együttjárást mutatott. A párra vonatkozó Verbális ellenségesség alskála pozitív, erős korrelációs kapcsolatban állt a párra vonatkozó Indokolatlan büntetéssel, míg negatívan, közepes mértékben korrelált több más, párra vonatkozó alskálával, így a Melegséggel, Érveléssel, Demokratikus részvétellel.

Az Indokolatlan büntetés alskála közepesen, pozitívan járt együtt a párra vonatkozó Indokolatlan büntetés alskálával. A párra vonatkozó Indokolatlan büntetés alskála közepes, negatív irányú korrelációs együttjárást mutatott a párra vonatkozó Melegség, párra vonatkozó Érvelés és a párra vonatkozó Demokratikus részvétel alskálákkal.

A Melegség alskála közepes mértékü, pozitív irányú együttjárást mutatott az Érvelés, Demokratikus részvétel alskálákkal. A párra vonatkozó Melegség alskála erősen, pozitívan járt együtt a párra vonatkozó Érvelés és a párra vonatkozó Demokratikus részvétel alskálákkal.

Az Érvelés alskála közepes, pozitív korrelációt mutatott a Demokratikus részvétellel, és a párra vonatkozó Érvelés alskálákkal. A párra vonatkozó Érvelés alskála erősen, pozitívan együtt járt a párra vonatkozó Demokratikus részvétel alskálával. 


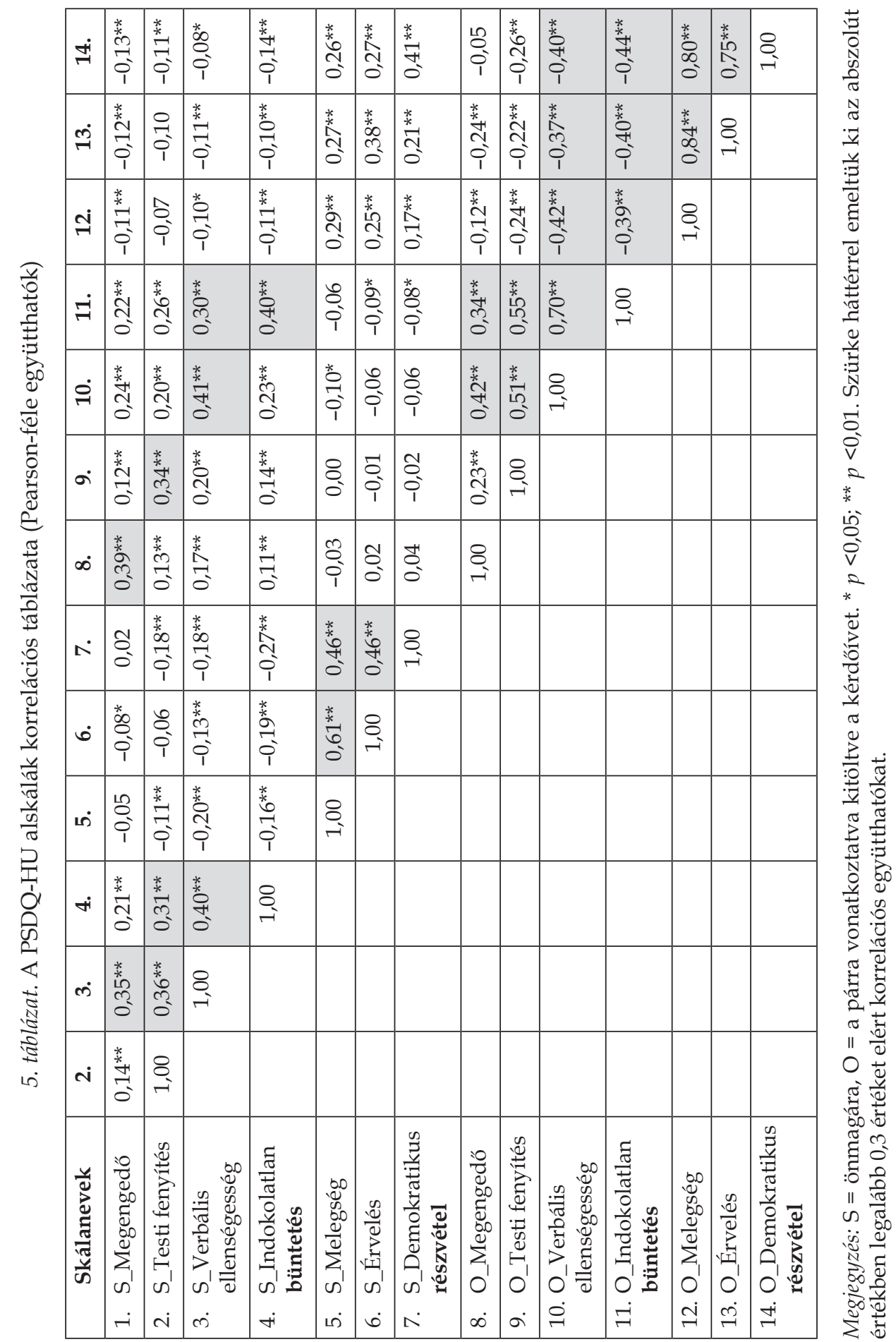




\subsection{A szülői nevelői stílus összefüggései a szociodemográfiai mutatókkal}

Elsőként azt szerettük volna ellenőrizni, hogy az egészségi állapotuk szerint megkülönböztetett csoportok különböznek-e a szülői nevelői stílusban, érdemes-e csoportbontásban végezni a további elemzéseket. Ezért a saját bevallás szerint a pszichoterápiás kezelés/gyógyszeres kezelés/pszichoterápiás és gyógyszeres kezelés megléte/nemléte alapján 4 csoportban, míg a krónikus szomatikus betegség megléte/nemléte alapján 2 csoportban (ld. 6. táblá$z a t)$ kétszempontos, független mintás varianciaanalízis segítségével teszteltük, hogy a PSDQ-HU kérdőív skáláin/alskáláin vannak-e kimutatható, szignifikáns különbségek, illetve interakciós hatások (ld. 7. táblázat).

6. táblázat. A minta csoportosítása a pszichológiai

és krónikus betegségek megléte/nemléte mentén

\begin{tabular}{|l|c|c|c|}
\hline \multirow{2}{*}{ Pszichológiai kezelés szerinti csoportok } & \multicolumn{2}{|c|}{$\begin{array}{c}\text { Krónikus betegség } \\
\text { szerinti csoportok }\end{array}$} & \multirow{2}{*}{ Összesen } \\
\cline { 2 - 3 } & Nincs & Van & \\
\hline Nem állt kezelés alatt & 481 & 79 & 560 \\
\hline Gyógyszeres kezelésben részesült & 12 & 7 & 19 \\
\hline Pszichoterápiában részesült & 72 & 23 & 95 \\
\hline $\begin{array}{l}\text { Gyógyszeres kezelésben és pszichoterápiában } \\
\text { részesült }\end{array}$ & 26 & 11 & 37 \\
\hline Összesen & 591 & 120 & 711 \\
\hline
\end{tabular}

Minden vizsgált változónk esetében, ahol bármely főhatásnak (pszichés 4 csoport, krónikus 2 csoport), és/vagy a kettőjük interakciójának szignifikanciája 0,05 alattinak bizonyult, az Omega-négyzet $\left(\omega^{2}\right)$ nem érte el még a 2\%-ot sem (legmagasabb érték 1,6\%-os magyarázó erő volt, ld. 7. táblázat). Így nem láttuk szükségét annak, hogy a további kapcsolatvizsgálatok során e tekintetben elkülönített almintákat alkalmazzunk. 
7. táblázat. A saját $(\mathrm{S})$ és a párra $(\mathrm{O})$ vonatkoztatott nevelői stílus alakulása mintánkon az egészségi állapot (pszichológiai és krónikus betegségek megléte/nemléte) szerint

\begin{tabular}{|c|c|c|c|c|c|c|c|}
\hline $\begin{array}{c}\text { Szülő́i } \\
\text { nevelói stílus }\end{array}$ & $F$ & $p$ & $\omega^{2}$ & $\begin{array}{c}\text { Szüloói } \\
\text { nevelói stílus }\end{array}$ & $F$ & $p$ & $\omega^{2}$ \\
\hline \multicolumn{4}{|l|}{ S_Megengedó } & \multicolumn{4}{|l|}{ O_Megengedő } \\
\hline pszichkez & 2,356 & 0,071 & 0,006 & pszichkez & 0,976 & 0,403 & 0 \\
\hline krbet & 0,121 & 0,728 & 0 & krbet & 1,803 & 0,18 & 0,001 \\
\hline pszichkez×krbet & 1,469 & 0,222 & 0,002 & pszichkez×krbet & 2,662 & 0,047 & 0,007 \\
\hline \multicolumn{4}{|l|}{ S_Testi fenyítés } & \multicolumn{4}{|l|}{ O_Testi fenyítés } \\
\hline pszichkez & 1,11 & 0,344 & 0 & pszichkez & 1,094 & 0,351 & 0 \\
\hline krbet & 0,231 & 0,631 & 0 & krbet & 0,053 & 0,818 & 0 \\
\hline pszichkez×krbet & 0,862 & 0,46 & 0 & pszichkez×krbet & 1,158 & 0,325 & 0,001 \\
\hline \multicolumn{4}{|c|}{ S_Verbális ellenségesség } & \multicolumn{4}{|c|}{ O_Verbális ellenségesség } \\
\hline pszichkez & 1,025 & 0,381 & 0 & pszichkez & 2,454 & 0,062 & 0,006 \\
\hline krbet & 0,389 & 0,533 & 0 & krbet & 0,213 & 0,644 & 0 \\
\hline pszichkez×krbet & 1,95 & 0,12 & 0,004 & pszichkez×krbet & 3,221 & 0,022 & 0,009 \\
\hline \multicolumn{4}{|c|}{ S_Indokolatlan büntetés } & \multicolumn{4}{|c|}{ O_Indokolatlan büntetés } \\
\hline pszichkez & 4,857 & 0,002 & 0,016 & pszichkez & 1,832 & 0,14 & 0,003 \\
\hline krbet & 1,221 & 0,27 & 0 & krbet & 0,596 & 0,44 & 0 \\
\hline pszichkez×krbet & 2,068 & 0,103 & 0,004 & pszichkez×krbet & 3,896 & 0,009 & 0,012 \\
\hline \multicolumn{4}{|l|}{ S_Melegség } & \multicolumn{4}{|l|}{ O_Melegség } \\
\hline pszichkez & 0,282 & 0,839 & 0 & pszichkez & 2,666 & 0,047 & 0,007 \\
\hline krbet & 7,693 & 0,006 & 0,009 & krbet & 5,149 & 0,024 & 0,006 \\
\hline pszichkez $\times$ krbet & 1,666 & 0,173 & 0,003 & pszichkez×krbet & 1,563 & 0,197 & 0,002 \\
\hline \multicolumn{4}{|l|}{ S_Érvelés } & \multicolumn{4}{|l|}{ O_Érvelés } \\
\hline pszichkez & 1,003 & 0,391 & 0 & pszichkez & 1,574 & 0,194 & 0,002 \\
\hline krbet & 1,654 & 0,199 & 0,001 & krbet & 2,304 & 0,129 & 0,002 \\
\hline pszichkez×krbet & 0,999 & 0,393 & 0 & pszichkez×krbet & 0,717 & 0,542 & 0 \\
\hline \multicolumn{4}{|c|}{ S_Demokratikus részvétel } & \multicolumn{4}{|c|}{ O_Demokratikus részvétel } \\
\hline pszichkez & 1,741 & 0,157 & 0,003 & pszichkez & 2,615 & 0,050 & 0,007 \\
\hline krbet & 0,279 & 0,598 & 0 & krbet & 1,386 & 0,239 & 0,001 \\
\hline pszichkez×krbet & 0,2 & 0,897 & 0 & pszichkez×krbet & 0,407 & 0,748 & 0 \\
\hline
\end{tabular}

Megjegyzés: $\mathrm{S}=$ önmagára, $\mathrm{O}$ = a párra vonatkoztatva kitöltve a kérdőívet, pszichkez = pszichológiai kezelés jelenléte, krbet = krónikus betegség jelenléte. 


\begin{tabular}{|c|c|c|c|c|c|c|c|c|c|c|}
\hline \multicolumn{4}{|c|}{ Cohen-d } & 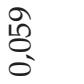 & $\begin{array}{l}\hat{\Delta} \\
\text { 今 } \\
\text { O }\end{array}$ & $\begin{array}{l}\text { Iै } \\
\text { O }\end{array}$ & $\begin{array}{l}\stackrel{+}{\infty} \\
\stackrel{0}{0}\end{array}$ & 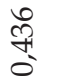 & $\begin{array}{l}\text { مे } \\
\text { On } \\
0\end{array}$ & $\underset{0}{\stackrel{+}{\sharp}}$ \\
\hline \multicolumn{4}{|c|}{ Welch- $d(p)$} & 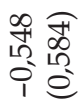 & 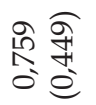 & $\begin{array}{l}\text { 成 } \\
\text { \& } \\
0 \\
0\end{array}$ & 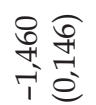 & 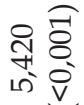 & 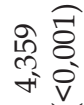 & 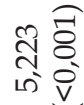 \\
\hline \multirow{2}{*}{ Zี } & Z & $\begin{array}{l}\text { : } \\
\text { in } \\
\text { II } \\
\Xi\end{array}$ & \multirow{2}{*}{ 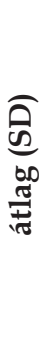 } & $\begin{array}{l}\text { ळ } \\
\infty \\
\text { é } \\
\text { సे } \\
\text { సे }\end{array}$ & 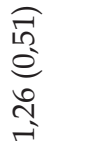 & 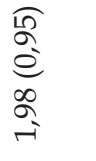 & 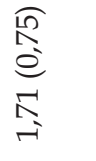 & 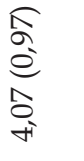 & $\begin{array}{l}\overparen{F} \\
\Xi \\
\infty \\
\infty \\
\infty \\
\infty\end{array}$ & 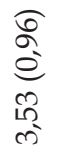 \\
\hline & 兌 & $\begin{array}{l}\underset{m}{*} \\
\stackrel{+}{1} \\
I \\
\Xi\end{array}$ & & \begin{tabular}{l} 
命 \\
é \\
\multirow{N}{N}{} \\
N
\end{tabular} & 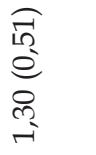 & 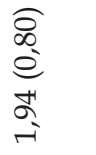 & 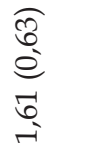 & $\begin{array}{l}\text { कू } \\
0 \\
e \\
\text { f } \\
\text { f }\end{array}$ & 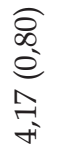 & 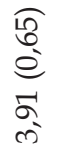 \\
\hline \multicolumn{4}{|c|}{ 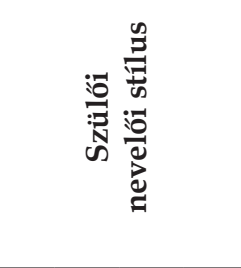 } & 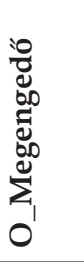 & 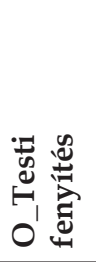 & 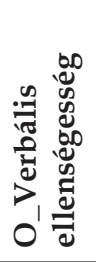 & 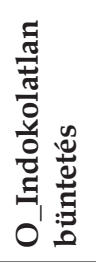 & 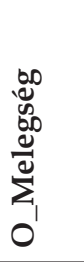 & 总 & 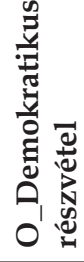 \\
\hline \multicolumn{4}{|c|}{ Cohen- $d$} & 긍 & 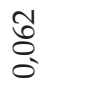 & $\begin{array}{l}\stackrel{1}{0} \\
\stackrel{0}{0}\end{array}$ & 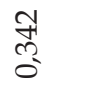 & $\begin{array}{l}1 \\
0 \\
0 \\
0\end{array}$ & 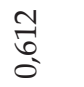 & $\begin{array}{l}\infty \\
\text { N } \\
\vdots\end{array}$ \\
\hline \multicolumn{4}{|c|}{ Welch- $d(p)$} & 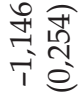 & 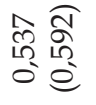 & $\begin{array}{l}\text { 공 } \\
\text { ป } ~ \\
0 \\
0\end{array}$ & 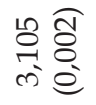 & 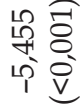 & 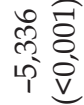 & 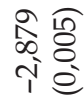 \\
\hline \multirow{2}{*}{$\begin{array}{l}\text { घี } \\
\text { Z }\end{array}$} & Z & $\begin{array}{l}\text { कू } \\
10 \\
11 \\
5\end{array}$ & \multirow{2}{*}{ 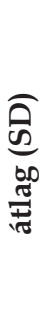 } & $\begin{array}{l}\text { శ్ } \\
\text { c } \\
\text { a } \\
\text { ने } \\
\text { i }\end{array}$ & 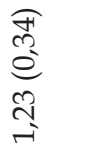 & $\begin{array}{l}\hat{\delta} \\
0 \\
e \\
2 \\
2 \\
-1\end{array}$ & 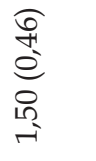 & 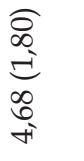 & 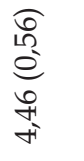 & $\begin{array}{l}0 \\
10 \\
0 \\
0 \\
\infty \\
\infty \\
\text { ले }\end{array}$ \\
\hline & 茜 & $\begin{array}{l}\text { (5) } \\
\text { F } \\
11 \\
\Xi\end{array}$ & & 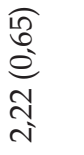 & 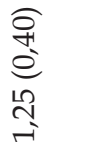 & 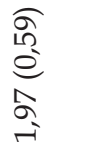 & 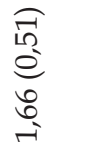 & 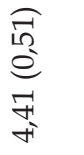 & 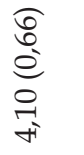 & 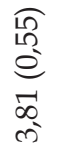 \\
\hline \multicolumn{4}{|c|}{ 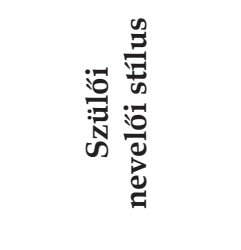 } & 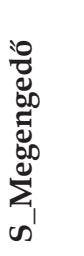 & 事透 & 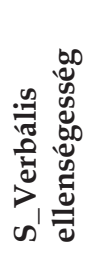 & 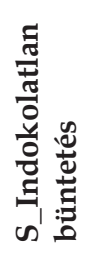 & 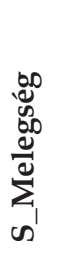 & 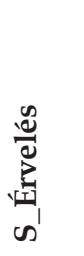 & 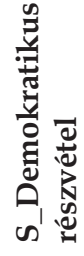 \\
\hline
\end{tabular}


A nemi különbségek vizsgálatakor a nők szignifikánsan magasabb átlagot értek el a Melegség, Érvelés és Demokratikus részvétel alskálákon, mint a férfiak. A férfiak pedig szignifikánsan magasabb értékeket mutattak a nőkhöz képest az Indokolatlan büntetés, a párra vonatkozó Melegség, a párra vonatkozó Érvelés és a párra vonatkozó Demokratikus részvétel alskálákon. A Cohen-féle hatásméret-mutató (Cohen- $d$ ) értéke mindegyik esetben 0,2 feletti volt, a terjedelme 0,283-0,612 (ez minden esetben közepes hatásmértéknek tekinthető, a nagynak/jelentósnek mondható kategóriát nem érte el egyik esetben sem). A részletes statisztikai eredmények a 8. táblázatban láthatók.

A továbbiakban a különböző demográfiai mutatók mentén végzett öszszehasonlítások a normalitás sérülését mutatták, ezért az elemzések során a robusztus eljárások eredményeit vettük figyelembe. Az eredményeket a 9-12. táblázatokban mutatjuk be részletesen.

Aszerint, hogy van-e testvére a szülőnek, a Melegség alskálán szignifikánsan magasabb átlagot értek el azok, akiknek nincs testvérük, mint akiknek van. A másik észlelésében a Melegség és az Érvelés alskálákon tapasztalható ugyanez. A Cohen-féle hatásméret-mutató értéke 0,2 felett volt a melegség észlelésénél, az érvelésnél 0,196 (9. táblázat), ami statisztikailag releváns, tehát legalább közepes mértékúnek mondható (nagyobb, igazán jelentősnek mondható különbségek nem voltak kimutathatók).

A lakóhely szerint szignifikáns különbség mutatkozik a fizikai fenyítésben és a demokratikus részvételben. A falun élő szülők szignifikánsan magasabb pontszámot értek el a testi fenyítés alkalmazásában, összehasonlítva a városban vagy fővárosban élőkkel. A fóvárosban élők magasabb pontot értek el a demokratikus részvételben, mint a vidéki városban élők, ugyanakkor a falun élőkkel összehasonlítva nincs szignifikáns eltérés. Az Eta-négyzet $\left(\eta^{2}\right)$ hatásméret-mutatók értéke nem érte el a 0,1-et, hogy statisztikailag relevánsnak számítson (10. táblázat).

Az iskolázottság és a nevelési stílus összefüggéseivel kapcsolatban a verbális ellenségesség/szidalmazás gyakoribb volt a felsőfokú iskolai végzettséggel rendelkezóknél, az indokolatlan büntetés pedig az érettségivel sem rendelkezők körében volt a legmagasabb. Azonban az Eta-négyzet hatásméret-mutatók egyik esetben sem érték el a 0,1 értéket (11. táblázat).

Ami a családi állapot és a nevelési stílus összefüggéseit illeti, az élettársi kapcsolatban élők körében gyakoribb volt a melegség dimenziója, mint a házasok körében, de mind az élettársi kapcsolatban élők, mind a házasok minden egyéb dimenzió tekintetében különböztek az elváltak és egyedül élők csoportjától. Az utóbbiak szignifikánsan alacsonyabb pontot érnek el az önpercepcióra vonatkozó fizikai fenyítés skálán, és magasabbat a pár észlelésére vonatkozó verbális ellenségesség/szidalmazás, valamint indokolatlan büntetés/büntetési stratégiák alskálákon, míg alacsonyabb pontot 
a párra vonatkozó melegség, érvelés, valamint demokratikus bánásmód észlelésében. Az Eta-négyzet hatásméret-mutatók azonban csak a párra vonatkozó melegség, érvelés és demokratikus részvétel esetén érték el a 0,1-et (12. táblázat).

\begin{tabular}{|c|c|c|c|c|c|c|c|c|c|}
\hline \multicolumn{3}{|c|}{$\frac{T}{i}$} & $\begin{array}{l}\text { Iै } \\
\text { o. } \\
0\end{array}$ & $\begin{array}{l}\stackrel{2}{2} \\
0 \\
0 \\
0\end{array}$ & $\begin{array}{l}12 \\
8 \\
0 \\
0\end{array}$ & $\begin{array}{l}\text { gे } \\
\text { 今 } \\
\text { i }\end{array}$ & 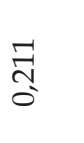 & 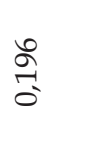 & 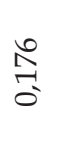 \\
\hline \multicolumn{3}{|c|}{$\frac{i}{\frac{1}{0}} \sqrt{3}$} & 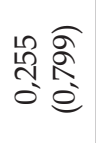 & 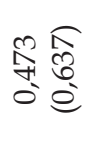 & 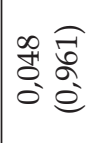 & 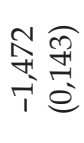 & 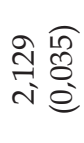 & 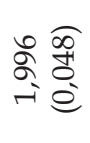 & 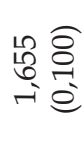 \\
\hline \multirow{2}{*}{$\sum_{\mathscr{D}}^{\stackrel{D}{\oplus}}$} & 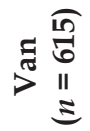 & \multirow{2}{*}{ 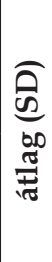 } & 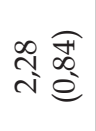 & ๙ิ & $\begin{array}{l}\widehat{\sigma} \widehat{\Omega} \\
\hat{\sigma}\end{array}$ & 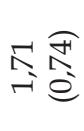 & $\begin{array}{l}\text { 긍 } \\
\text { F }\end{array}$ & 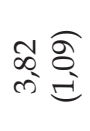 & $\begin{array}{l}\hat{n} \widehat{\varrho} \\
\text { के }\end{array}$ \\
\hline & 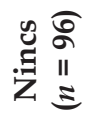 & & $\begin{array}{l}\text { 尺 } \\
\text { NE }\end{array}$ & 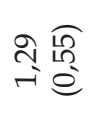 & 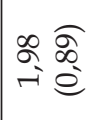 & 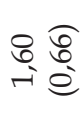 & 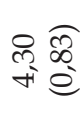 & 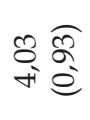 & 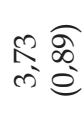 \\
\hline \multicolumn{3}{|c|}{ 涪 } & 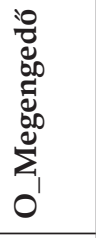 & 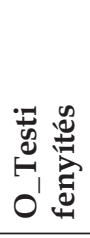 & 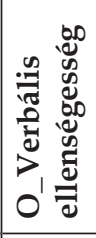 & 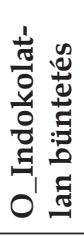 & 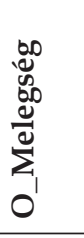 & 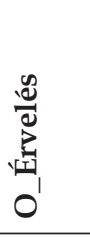 & 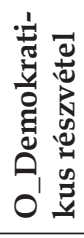 \\
\hline \multicolumn{3}{|c|}{ 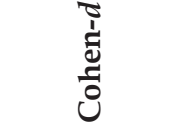 } & $\begin{array}{l}\text { ले } \\
\text { लू }\end{array}$ & $\begin{array}{l}\overline{8} \\
8 \\
0\end{array}$ & 今̂ & 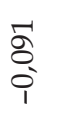 & 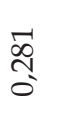 & 㝘 & $\begin{array}{l}0 \\
\text { s. } \\
0 \\
0\end{array}$ \\
\hline \multicolumn{3}{|c|}{$\frac{\frac{1}{2}}{\frac{1}{2}} \sqrt{3}$} & 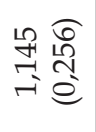 & 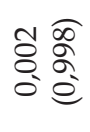 & $\begin{array}{ll}1 & \overbrace{} \\
\infty & 1 \\
0 & 1 \\
12 & 12 \\
0 & \varrho\end{array}$ & 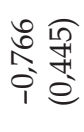 & 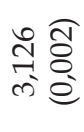 & 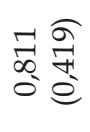 & 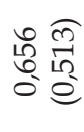 \\
\hline \multirow{2}{*}{ 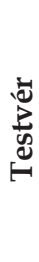 } & 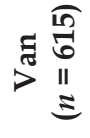 & \multirow{2}{*}{ 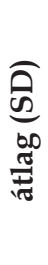 } & 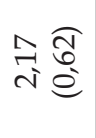 & ત્ 犬̂ & 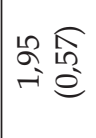 & 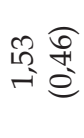 & 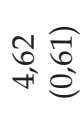 & 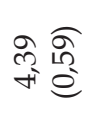 & 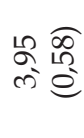 \\
\hline & 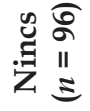 & & $\begin{array}{l}\hat{N} \widehat{E} \\
\text { NE }\end{array}$ & 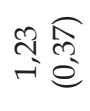 & 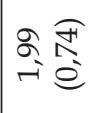 & 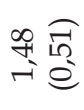 & 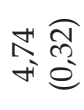 & 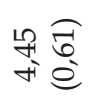 & 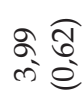 \\
\hline & 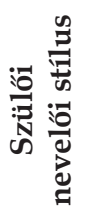 & & 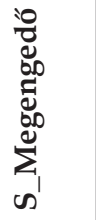 & 焉递 & 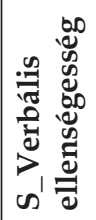 & 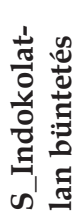 & 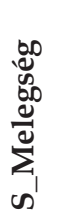 & 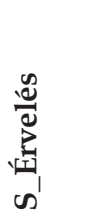 & 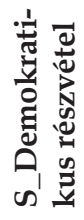 \\
\hline
\end{tabular}


A Parenting Styles and Dimensions Questionnaire hazai alkalmazásával szerzett tapasztalatok 179

\begin{tabular}{|c|c|c|c|c|c|c|c|c|c|c|}
\hline \multicolumn{4}{|c|}{$\cong$} & Бे & $\begin{array}{l}8 \\
8 \\
0\end{array}$ & 형 & $\begin{array}{l}\text { 옹 } \\
8 \\
0\end{array}$ & \& & б. & 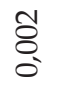 \\
\hline \multicolumn{4}{|c|}{ 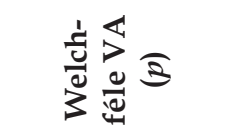 } & 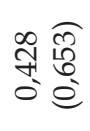 & 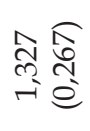 & 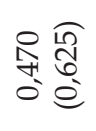 & 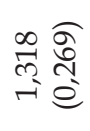 & 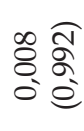 & 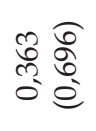 & 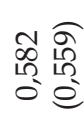 \\
\hline \multirow{3}{*}{$\begin{array}{l}\frac{2}{2} \\
\frac{2}{0} \\
\frac{1}{3} \\
\end{array}$} & $\frac{\Xi}{\sqrt{\tau}}$ & $\begin{array}{l}\text { ণิ } \\
\text { ㄱ } \\
\text { II } \\
\Xi\end{array}$ & \multirow{3}{*}{ 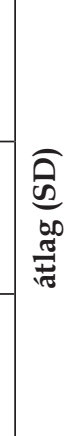 } & 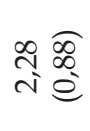 & 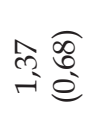 & 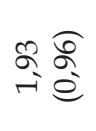 & $\begin{array}{l}\mathscr{\infty} \\
-\infty \\
-\infty\end{array}$ & $\begin{array}{l}\text { H } \\
\text { 合 }\end{array}$ & $\begin{array}{l}\infty \mathcal{F} \\
\infty \\
\infty \\
\infty\end{array}$ & $\begin{array}{l}\infty \\
\stackrel{2}{\Omega} \\
n^{2}\end{array}$ \\
\hline & ஓ & $\begin{array}{l}\text { बे } \\
\text { के } \\
\text { II } \\
\Xi\end{array}$ & & 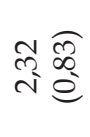 & 낭 & $\begin{array}{l}5 \widehat{\sigma} \\
\text { సీ }\end{array}$ & 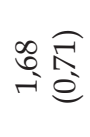 & $\begin{array}{l}\stackrel{2}{\curvearrowright} \\
\stackrel{\infty}{+} \stackrel{\infty}{\varrho}\end{array}$ & $\begin{array}{l}\infty \approx \\
\infty \\
\infty \\
\infty \\
\infty\end{array}$ & 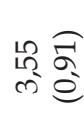 \\
\hline & 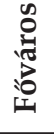 & $\begin{array}{l}\text { Оి } \\
\text { ల } \\
\text { II } \\
\Xi\end{array}$ & & 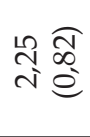 & 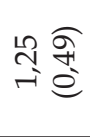 & $\begin{array}{l}\text { 을 } \\
-i \bar{e}\end{array}$ & 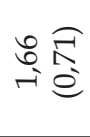 & 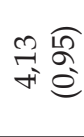 & 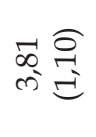 & 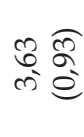 \\
\hline \multicolumn{4}{|c|}{ 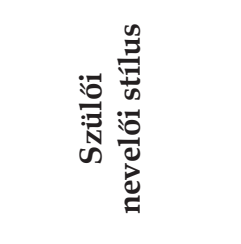 } & 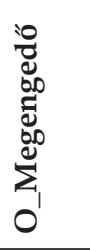 & 跑 & 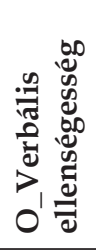 & 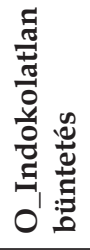 & 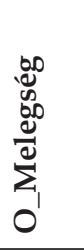 & 党 & 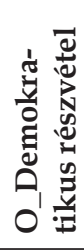 \\
\hline \multicolumn{4}{|c|}{$\cong$} & 0 & $\begin{array}{l}\stackrel{+}{1} \\
\text { O } \\
0\end{array}$ & $\begin{array}{l}5 \\
8 \\
8 \\
\circ\end{array}$ & 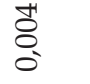 & 0 & $\begin{array}{l}5 \\
8 \\
8 \\
\circ\end{array}$ & $\begin{array}{l}\text { 구 } \\
\text { o } \\
0\end{array}$ \\
\hline \multicolumn{4}{|c|}{ 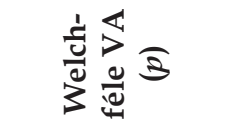 } & 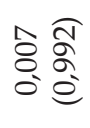 & 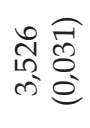 & 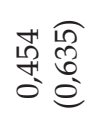 & 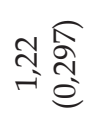 & 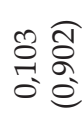 & 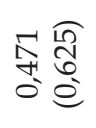 & 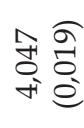 \\
\hline \multirow{3}{*}{ 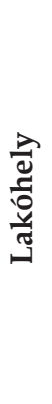 } & $\frac{\Xi}{\text { న్ }}$ & $\begin{array}{c}\text { สิ } \\
\text { ㄱ } \\
\text { II } \\
\Xi\end{array}$ & \multirow{3}{*}{ 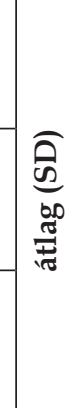 } & 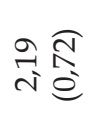 & 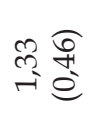 & 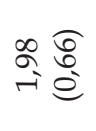 & 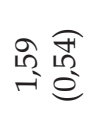 & 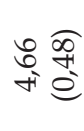 & 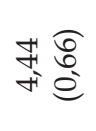 & 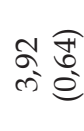 \\
\hline & 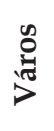 & 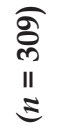 & & 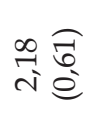 & 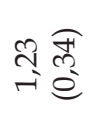 & 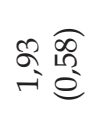 & 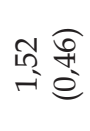 & 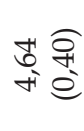 & 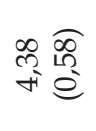 & 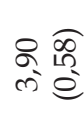 \\
\hline & 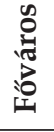 & $\begin{array}{l}\text { ठి } \\
\text { I } \\
\text { II } \\
5\end{array}$ & & 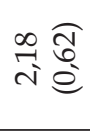 & $\begin{array}{l}\text { 조 శ్ } \\
-i e\end{array}$ & $\begin{array}{l}\hat{\alpha} \widehat{\delta} \\
-i e\end{array}$ & 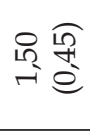 & 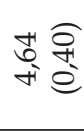 & 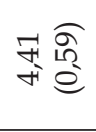 & 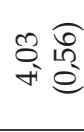 \\
\hline & مَ & & & 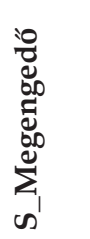 & 事 & 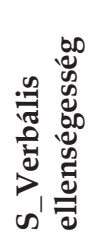 & 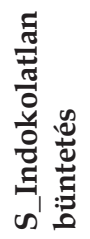 & 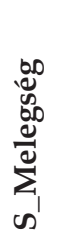 & 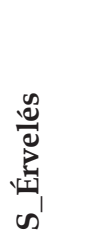 & 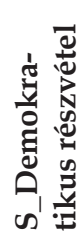 \\
\hline
\end{tabular}




\begin{tabular}{|c|c|c|c|c|c|c|c|c|c|c|}
\hline \multicolumn{4}{|c|}{$\cong$} & 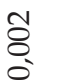 & 㝑 & $\begin{array}{l}8 \\
8 \\
0\end{array}$ & $\begin{array}{l}8 \\
8 \\
0\end{array}$ & $\begin{array}{l}\infty \\
8 \\
0 \\
0\end{array}$ & $\begin{array}{l}0 \\
8 \\
0 \\
0\end{array}$ & $\begin{array}{l}8 \\
8 \\
0\end{array}$ \\
\hline \multicolumn{4}{|c|}{ 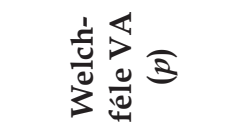 } & 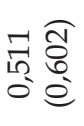 & $\begin{array}{l}\hat{N} \\
\text { o } \\
0 \\
0 \\
0\end{array}$ & 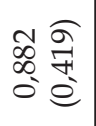 & \begin{tabular}{l}
$0 \widehat{\mathbb{1}}$ \\
$\infty$ \\
$\infty$ \\
\multirow{+}{*}{} \\
0
\end{tabular} & 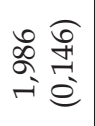 & 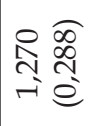 & 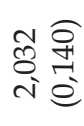 \\
\hline \multirow{3}{*}{ 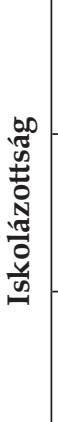 } & 总 & 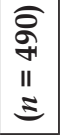 & \multirow{3}{*}{ 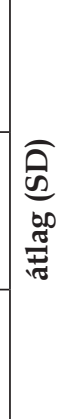 } & 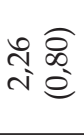 & 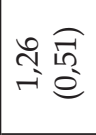 & 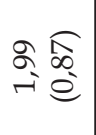 & 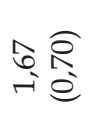 & 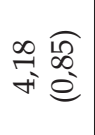 & 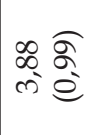 & 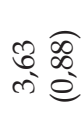 \\
\hline & 离 & $\begin{array}{l}\text { } \\
2 \\
\text { ?1 } \\
\text { II } \\
5\end{array}$ & & $\begin{array}{l}\text { से } \\
\text { ஸे }\end{array}$ & 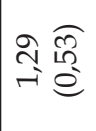 & 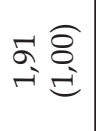 & 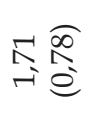 & $\begin{array}{l}\text { 용 } \\
\stackrel{0}{\circ} \\
\text { fi }\end{array}$ & 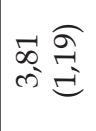 & 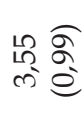 \\
\hline & 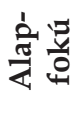 & $\begin{array}{l}\text { ลี } \\
\text { II } \\
\Xi\end{array}$ & & 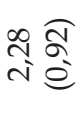 & $\begin{array}{ll}m & \hat{0} \\
m & 1 \\
-i & e\end{array}$ & 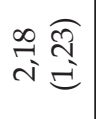 & 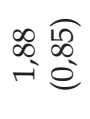 & 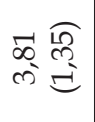 & $\begin{array}{l}\text { F્ } \\
\text { क }\end{array}$ & $\begin{array}{l}\infty \\
\stackrel{\sigma}{\sigma}= \\
\stackrel{\sigma}{=}\end{array}$ \\
\hline \multicolumn{4}{|c|}{$\frac{\frac{\pi}{\pi}}{\frac{\pi}{\pi}}$} & 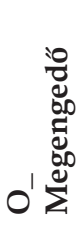 & 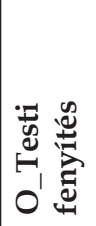 & 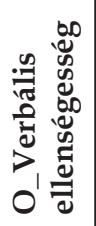 & 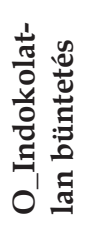 & 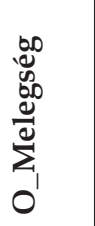 & 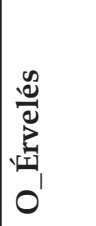 & 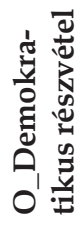 \\
\hline \multicolumn{4}{|c|}{$\cong$} & 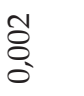 & 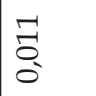 & 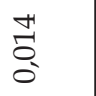 & $\stackrel{\stackrel{L}{S}}{\mathrm{O}}$ & 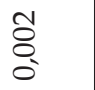 & $\begin{array}{l}5 \\
8 \\
0\end{array}$ & $\begin{array}{l}\text { đิ } \\
8 \\
0\end{array}$ \\
\hline \multicolumn{4}{|c|}{ 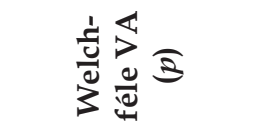 } & 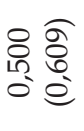 & $\begin{array}{ll}0 & 0 \\
\alpha & 0 \\
\alpha & 0 \\
ن & 0\end{array}$ & 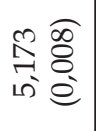 & 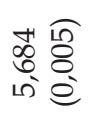 & 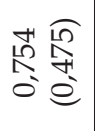 & $\begin{array}{ll}\infty & \widetilde{\alpha} \\
\hat{N} & 0 \\
0 & 0 \\
0 & 0\end{array}$ & 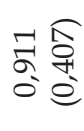 \\
\hline \multirow{3}{*}{ 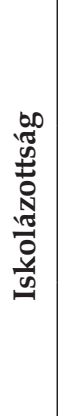 } & 家 & $\begin{array}{l}\text { \&్} \\
\text { + } \\
\text { II } \\
\text { క }\end{array}$ & \multirow{3}{*}{ 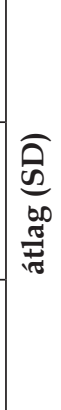 } & 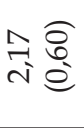 & 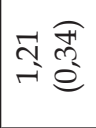 & 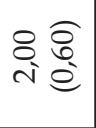 & $\begin{array}{l}\text { 声 } \\
\stackrel{f}{f}\end{array}$ & 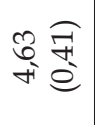 & 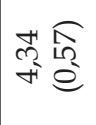 & 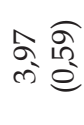 \\
\hline & 离 & $\begin{array}{l}5 \\
2 \\
11 \\
5\end{array}$ & & 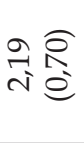 & స̂ & 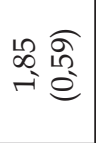 & 余 & \begin{tabular}{l}
$\widehat{\overparen{P}}$ \\
\multirow{+}{*}{}
\end{tabular} & 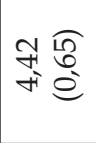 & 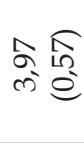 \\
\hline & 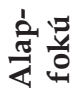 & \begin{tabular}{|l}
12 \\
$N$ \\
11 \\
$\Xi$
\end{tabular} & & 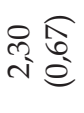 & 웛 & 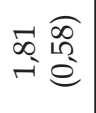 & 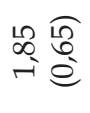 & 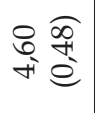 & 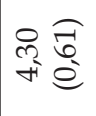 & 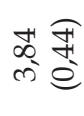 \\
\hline \multicolumn{4}{|c|}{ 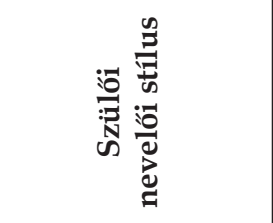 } & 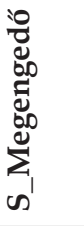 & 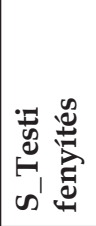 & 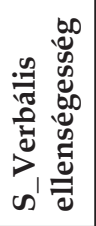 & 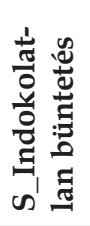 & 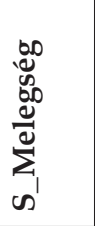 & 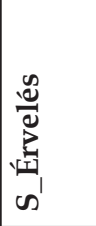 & 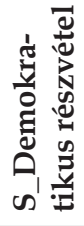 \\
\hline
\end{tabular}




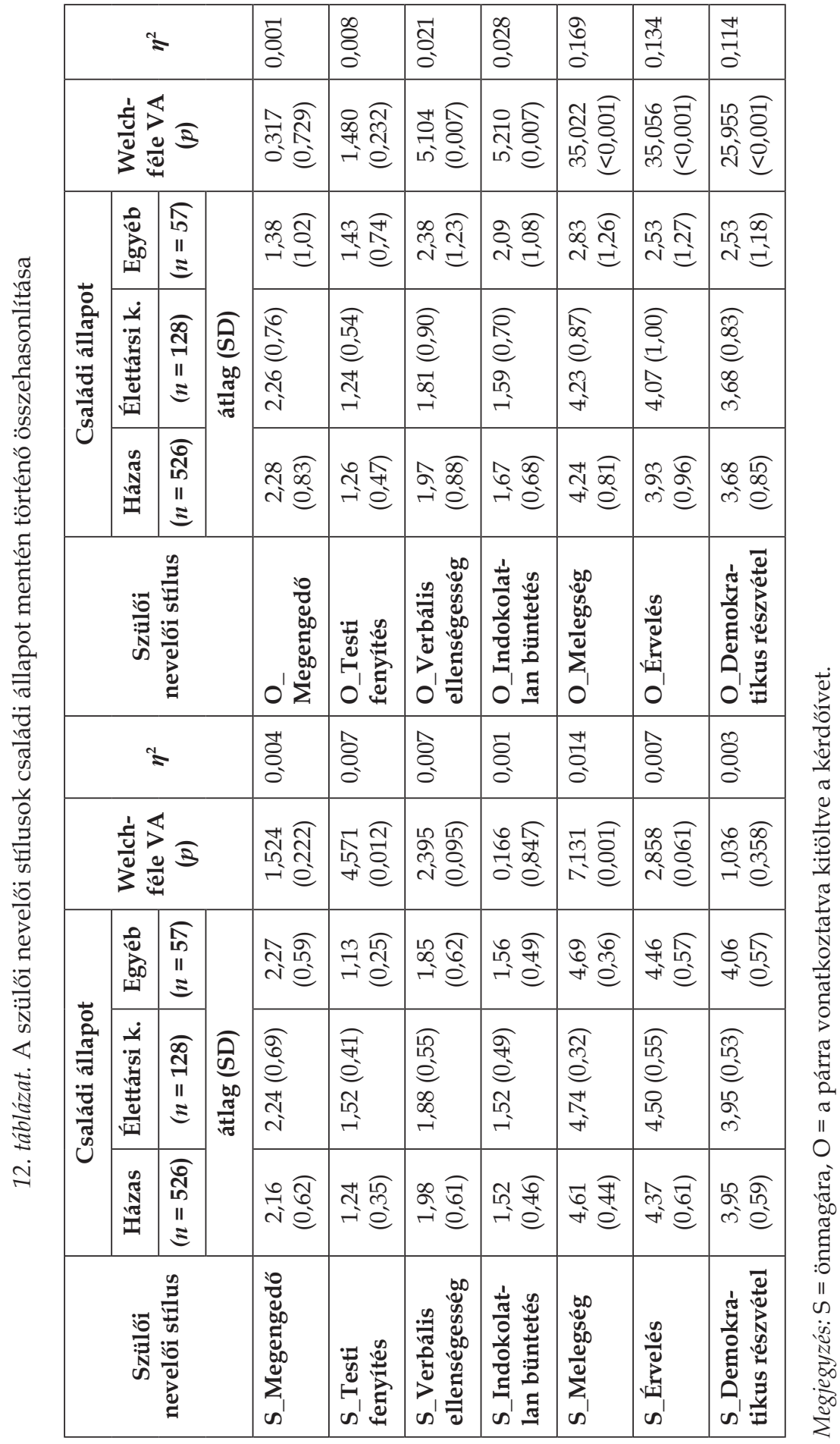


Az alapján, hogy milyennek értékelték az anyagi helyzetüket, 4 csoportot hoztunk létre, úgymint átlag alatti (1), kissé az átlag alatti (2), átlagos (3) és átlag feletti (4). Annak alapján, hogy az önmegítélésük szerint mennyire járulnak hozzá a családi egzisztencia megteremtéséhez, szintén 4 csoportba soroltuk be a résztvevőket: egyedül biztosítom (1), nagyban hozzájárulok (2), a párommal azonos mértékben járulok hozzá (3), nem számottevő mértékben járulok hozzá (4). A minta csoportosítását a 13. táblázat szemlélteti. Kétszempontos varianciaanalízissel vizsgáltuk meg az anyagi helyzet és az egzisztenciához való hozzájárulás kapcsolatát a szülői nevelői stílussal. Eredményeink szerint vannak szignifikáns összefüggések a verbális ellenségesség (szidalmazás), fizikai fenyítés, a másik melegségének, érvelésének és demokratikus részvételének észlelésében, az anyagi helyzet és egzisztenciához való hozzájárulás mentén, de ezek hatása sehol nem éri el a 6\%-ot, így a részletes szöveges bemutatást szakmailag nem tartjuk relevánsnak (14. táblázat).

13. táblázat. A minta csoportosítása az anyagi helyzet és a családi egzisztenciához való hozzájárulás szerint

\begin{tabular}{|l|c|c|c|c|c|}
\hline \multirow{2}{*}{$\begin{array}{l}\text { Anyagi } \\
\text { helyzet }\end{array}$} & \multicolumn{5}{|c|}{ Egzisztenciához való hozzájárulás } \\
\cline { 2 - 6 } & $\begin{array}{c}\text { egyedül } \\
\text { biztosítom }\end{array}$ & $\begin{array}{c}\text { nagyban } \\
\text { hozzá- } \\
\text { járulok }\end{array}$ & $\begin{array}{c}\text { a párommal } \\
\text { azonos } \\
\text { mértékben } \\
\text { járulok hozzá }\end{array}$ & $\begin{array}{c}\text { nem számottevó } \\
\text { mértékben } \\
\text { járulok hozzá }\end{array}$ & Összesen \\
\hline átlag alatti & 11 & 17 & 19 & 26 & 73 \\
\hline $\begin{array}{l}\text { kissé az } \\
\text { átlag alatti }\end{array}$ & 13 & 63 & 82 & 88 & 246 \\
\hline átlagos & 29 & 76 & 113 & 67 & 285 \\
\hline átlag feletti & 7 & 33 & 37 & 30 & 107 \\
\hline Összesen & 60 & 189 & 251 & 211 & 711 \\
\hline
\end{tabular}

A szülők életkorának (átlag $=38,86$ év, SD =7,52 év), a legidősebb gyermek életkorának (átlag =9,71 év, SD = 7,78 év) és a szülöi kapcsolat hosszának (átlag = 9,86 év, SD = 7,42 év) (azaz a családi állapot mióta tart) is megvizsgáltuk az együttjárását a szülői nevelói stílusokkal, de a Pearson-féle korrelációs együtthatók értéke sehol sem érte el abszolút értékben a 0,3-at (szülők életkora $r=|0,017|-|0,215|$; gyermek életkora $r=|0,004|-|0,232|$; a párkapcsolat hossza $r=|0,003|-|0,192|)$, így a 711 fós mintanagyság mellett szakmailag nem tartjuk relevánsnak a kapott összefüggéseket. 
14. táblázat. A szülői nevelői stílus alakulása mintánkon az anyagi helyzet és az egzisztenciához való hozzájárulás szerint

\begin{tabular}{|c|c|c|c|c|c|c|c|}
\hline $\begin{array}{c}\text { Szülői } \\
\text { nevelói stílus }\end{array}$ & $F$ & $p$ & $\omega^{2}$ & $\begin{array}{c}\text { Szülő́i } \\
\text { nevelói stílus }\end{array}$ & $F$ & $p$ & $\omega^{2}$ \\
\hline \multicolumn{4}{|l|}{ S_Megengedő } & \multicolumn{4}{|l|}{ O_Megengedő } \\
\hline anyagi & 0,977 & 0,394 & 0 & anyagi & 0,888 & 0,447 & 0 \\
\hline egziszt & 0,857 & 0,463 & 0 & egziszt & 0,129 & 0,943 & 0 \\
\hline anyagi×egziszt & 1,592 & 0,114 & 0,007 & anyagi×egziszt & 0,64 & 0,763 & 0 \\
\hline \multicolumn{4}{|l|}{ S_Testi fenyítés } & O_Testi fenyítés & & & \\
\hline anyagi & 1,17 & 0,32 & 0,001 & anyagi & 1,384 & 0,247 & 0,002 \\
\hline egziszt & 0,372 & 0,773 & 0 & egziszt & 1,195 & 0,311 & 0,001 \\
\hline anyagi×egziszt & 2,202 & 0,02 & 0,015 & anyagi×egziszt & 0,49 & 0,882 & 0 \\
\hline \multicolumn{4}{|c|}{ S_Verbális ellenségesség } & \multicolumn{4}{|c|}{ O_Verbális ellenségesség } \\
\hline anyagi & 3,084 & 0,027 & 0,009 & anyagi & 0,761 & 0,516 & 0 \\
\hline egziszt & 0,09 & 0,965 & 0 & egziszt & 2,94 & 0,033 & 0,008 \\
\hline anyagi×egziszt & 0,782 & 0,633 & 0 & anyagi×egziszt & 1,633 & 0,102 & 0,008 \\
\hline \multicolumn{4}{|c|}{ S_Indokolatlan büntetés } & \multicolumn{4}{|c|}{ O_Indokolatlan büntetés } \\
\hline anyagi & 1,818 & 0,143 & 0,003 & anyagi & 1,788 & 0,148 & 0,003 \\
\hline egziszt & 0,865 & 0,459 & 0 & egziszt. & 4,114 & 0,007 & 0,013 \\
\hline anyagi×egziszt & 0,997 & 0,441 & 0 & anyagi×egziszt & 0,43 & 0,919 & 0 \\
\hline \multicolumn{4}{|l|}{ S_Melegség } & \multicolumn{4}{|l|}{ O_Melegség } \\
\hline anyagi & 0,337 & 0,798 & 0 & anyagi & 7,368 & $<0,001$ & 0,024 \\
\hline egziszt & 2,497 & 0,059 & 0,006 & egziszt & 15,944 & $<0,001$ & 0,057 \\
\hline anyagi×egziszt & 0,974 & 0,46 & 0 & anyagi×egziszt & 2,339 & 0,013 & 0,015 \\
\hline \multicolumn{4}{|l|}{ S_Érvelés } & \multicolumn{4}{|l|}{ O_Érvelés } \\
\hline anyagi & 1,987 & 0,115 & 0,004 & anyagi & 6,015 & $<0,001$ & 0,019 \\
\hline egziszt & 1,538 & 0,203 & 0,002 & egziszt & 13,509 & $<0,001$ & 0,049 \\
\hline anyagi×egziszt & 1,024 & 0,419 & 0 & anyagi×egziszt & 2,072 & 0,03 & 0,012 \\
\hline \multicolumn{4}{|c|}{ S_Demokratikus részvétel } & \multicolumn{4}{|c|}{ O_Demokratikus részvétel } \\
\hline anyagi & 0,946 & 0,418 & 0 & anyagi & 5,086 & 0,002 & 0,016 \\
\hline egziszt & 1,935 & 0,123 & 0,004 & egziszt & 9,834 & $<0,001$ & 0,035 \\
\hline anyagi×egziszt & 0,741 & 0,671 & 0 & anyagi×egziszt & 2,171 & 0,022 & 0,014 \\
\hline
\end{tabular}

Megjegyzés: $\mathrm{S}$ = önmagára, $\mathrm{O}$ = a párra vonatkoztatva kitöltve a kérdőívet, anyagi = anyagi helyzet, egziszt = egzisztenciához való hozzájárulás. 


\subsection{A szülői nevelői stílus összefüggéseinek vizsgálata néhány pszichológiai és párkapcsolati jellemzővel}

A szülői nevelói stílus korrelátumaira vonatkozó hipotéziseinket korrelációs elemzéssel teszteltük. A Pearson-féle korrelációs együtthatókat a 15. táblázatban mutatjuk be részletesen. Az alábbiakban összefoglaljuk a legfontosabb eredményeket.

A szülői nevelői stílus és párkapcsolati intimitás kapcsolatának, azaz a PSDQ-HU és IBM-HU kérdőívek korrelációs vizsgálatának eredményei szerint csak a pár szülői nevelői stílusának észlelése mutat számottevő $(r \geq|0,3|)$ együttjárást a párkapcsolati intimitás, gondoskodás és kontroll dimenzióival. Közepes vagy erósebb, pozitív irányú korreláció van az észlelt gondoskodás és a pár melegségének, érvelésének és demokratikus részvételének észlelete között, emellett negatív irányú és valamivel gyengébb, de közepes mértékúnek mondható a korreláció a gondoskodás és a pár indokolatlan büntetésének és verbális ellenségességének észlelete között. A kontrollal a pár indokolatlan büntetése és verbális ellenségessége is közepesen, pozitívan korrelálnak, míg negatív irányú az együttjárás a pár melegségének, érvelésének és demokratikus részvételének az észleletével. Hipotézisünk (a), miszerint a párkapcsolati intimitásban az észlelt gondoskodás az irányító szülői nevelói stílus észlelésével pozitívan, a kontroll negatívan jár együtt, míg az észlelt kontroll a megengedő és tekintélyelvú stílusokkal korrelál pozitívan, a gondoskodás pedig negatívan, részben teljesült.

A felnőtt kötơdés (ECR-RS) az anyához és az apához gyenge (pozitív és negatív) együttjárást mutatott, viszont a párhoz való kötődés közepes erősségú, szignifikáns (pozitív és negatív) együttjárást jelzett a pár szülői nevelői stílusának észlelésével. Az a hipotézisünk (b), hogy a felnőtt kötődés biztonsága a szülőkkel az irányító szülői nevelői stílus észlelésével jár együtt, azaz a kapcsolati szorongás és elkerülés negatívan korrelál az irányító, míg pozitívan korrelál a megengedő és a tekintélyelvú stílusokkal, részben alátámasztást nyert.

A párral kapcsolatos szorongás és elkerülés is közepesen, pozitívan korrelált a pár verbális ellenségességének és indokolatlan büntetésének észlelésével, és mindkét skála negatívan, közepesen korrelált a pár melegségének, érvelésének és demokratikus részvételének az észlelésével. Így feltételezésünk (c), miszerint a párkapcsolati kötődés biztonságának növekedése az irányító szülői nevelői stílus észlelésével jár együtt, azaz a kapcsolati szorongás és elkerülés negatívan korrelál az irányító, míg pozitívan korrelál a megengedó és tekintélyelvú stílusokkal, részben teljesült. 
A párkapcsolati elégedettség (RAS) a pár észlelésével pozitívan, közepesen korrelál a melegség, érvelés és demokratikus részvétel alskálák esetében, közepes, negatív együttjárást mutat verbális ellenségességgel és indokolatlan büntetéssel. Feltételezésünk (d), hogy a párkapcsolati elégedettség az irányító szülői nevelői stílus észlelésével jár együtt, igazolást nyert a párészlelésre vonatkozóan.

A vonásszorongás (STAI-T) a pár autoritatív szülői nevelői stílusának észlelésével mutat szignifikáns, közepes erősségú negatív korrelációt, azaz a szorongás növekedésével csökken annak a mértéke, hogy a párt melegnek, érvelőnek és demokratikus részvételúnek lássa a gyermekükkel kapcsolatban. A Zung-féle depresszió kérdőíven elért pontszám 3 alskála esetében is közepesen, negatívan korrelál a PSDQ-HU pár észlelésével. Ezek a következők: melegség, érvelés és demokratikus részvétel. Az eredményeink szerint minél magasabb pontszámot ér el valaki a Zung-féle depressziót becslő skálán, annál kevésbé látja meleg, érveló és demokratikus részvételúnek a párja nevelői stílusát, illetve minél kevésbé látja valaki melegnek, érvelőnek és demokratikus részvételúnek a párját a gyermekükkel kapcsolatban, annál magasabb értéket ér el a depresszió skálán. Hipotézisünk (e), miszerint a szülő vonásszorongása és depresszióra való hajlama negatív együttjárást mutat az irányító nevelői stílussal, igazolást nyert a párészleléssel kapcsolatban.

A társas támasz (MOS) észlelése és a pár autoritatív szülői nevelői stílusának észlelése közepes erősségú, pozitív együttjárást mutat, vagyis az érzelmi-információs támasz, a pozitív szociális interakción alapuló támasz és az instrumentális támasz is együtt jár a melegséggel, érveléssel és demokratikus részvétellel. Az a feltételezésünk (f), hogy a társas támogatás észlelése és az irányító nevelői stílus pozitív együttjárást mutat, alátámasztást nyert a párészlelésre vonatkozóan. 


\begin{tabular}{|c|c|c|c|c|c|c|c|c|c|c|}
\hline \multirow{3}{*}{$\stackrel{n}{\infty}$} & \multirow{3}{*}{ 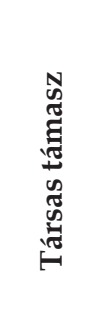 } & Instrumentális & 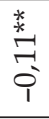 & $\begin{array}{l}\text { k } \\
\text { o } \\
0 \\
0 \\
1\end{array}$ & $\begin{array}{l}8 \\
0 \\
1\end{array}$ & $\begin{array}{l}\text { t' } \\
\stackrel{+}{1}\end{array}$ & $\begin{array}{l}\text { ò } \\
0 \\
0 \\
0\end{array}$ & $\begin{array}{l}8 \\
0 \\
0\end{array}$ & $\begin{array}{l}8 \\
8 \\
0\end{array}$ & \begin{tabular}{l}
$*$ \\
\multirow{2}{*}{} \\
$\stackrel{2}{0}$ \\
0 \\
1
\end{tabular} \\
\hline & & $\begin{array}{l}\text { Pozitív szociális } \\
\text { interakció. }\end{array}$ & $\begin{array}{l}* \\
* \\
\vdots \\
0 \\
1\end{array}$ & $\begin{array}{l}* \\
8 \\
0 \\
0 \\
1\end{array}$ & $\begin{array}{l}4 \\
0 \\
0 \\
1\end{array}$ & $\begin{array}{l}\text { * } \\
0 \\
0 \\
0 \\
1\end{array}$ & $\begin{array}{l}\stackrel{*}{*} \\
\stackrel{*}{*} \\
0\end{array}$ & 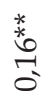 & $\begin{array}{l}\text { * } \\
\stackrel{*}{7} \\
0\end{array}$ & $\begin{array}{l}* \\
0 \\
0 \\
0 \\
1\end{array}$ \\
\hline & & $\begin{array}{c}\text { Érzelmi- } \\
\text { információs t. }\end{array}$ & $\begin{array}{l}\text { So } \\
\text { 心 } \\
1\end{array}$ & $\begin{array}{l}\text { O⿱ } \\
0 \\
0 \\
0 \\
1\end{array}$ & $\begin{array}{l}3 \\
0 \\
0 \\
1\end{array}$ & $\begin{array}{l}0 \\
0 \\
0 \\
1\end{array}$ & 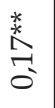 & 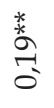 & 䓠 & $\begin{array}{l}\text { * } \\
\text { o } \\
0 \\
\text { i }\end{array}$ \\
\hline ZUNG & \multicolumn{2}{|c|}{ Depresszió } & \begin{tabular}{l}
$*$ \\
\multirow{2}{*}{} \\
$\stackrel{2}{N}$ \\
0
\end{tabular} & $\begin{array}{l}\text { t' } \\
\text { Oे }\end{array}$ & 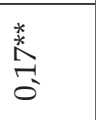 & 烍 & 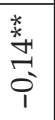 & 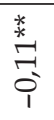 & $\begin{array}{l}* \\
0 \\
0 \\
0 \\
1\end{array}$ & $\begin{array}{l}\underbrace{*}_{*} \\
\stackrel{0}{0} \\
\stackrel{0}{0}\end{array}$ \\
\hline STAI-T & \multicolumn{2}{|c|}{ Vonásszorongás } & \begin{tabular}{l} 
* \\
\multirow{2}{0}{} \\
N \\
$\vdots$
\end{tabular} & $\begin{array}{l}* \\
0 \\
0 \\
0\end{array}$ & 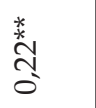 & 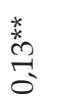 & \begin{tabular}{l} 
* \\
\multirow{2}{*}{} \\
$\stackrel{2}{7}$ \\
1 \\
1
\end{tabular} & $\begin{array}{l}1 \\
0 \\
0 \\
1\end{array}$ & $\begin{array}{l}\hat{O} \\
\stackrel{1}{0} \\
1\end{array}$ & $\stackrel{\text { * }}{\stackrel{*}{*}}$ \\
\hline RAS-H & \multicolumn{2}{|c|}{$\begin{array}{l}\text { Párkapcsolati } \\
\text { elégedettség }\end{array}$} & 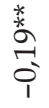 & $\begin{array}{l}\text { tr } \\
\text { Oे } \\
\text { i }\end{array}$ & $\begin{array}{l}* \\
0 \\
0 \\
0 \\
1\end{array}$ & $\begin{array}{l}0 \\
0 \\
0 \\
1\end{array}$ & $\begin{array}{l}+ \\
\stackrel{8}{0} \\
\end{array}$ & 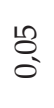 & $\begin{array}{l}5 \\
0 \\
0 \\
0 \\
1\end{array}$ & $\begin{array}{l}* \\
\stackrel{*}{*} \\
\stackrel{*}{N} \\
\vdots \\
i\end{array}$ \\
\hline \multirow{6}{*}{ 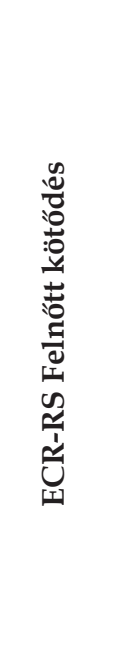 } & \multirow{2}{*}{ 气ี } & Szorongás & స̃ & 莡 & $\begin{array}{l}x_{0}^{*} \\
\stackrel{0}{*}\end{array}$ & 菜 & $\begin{array}{l}8 \\
0 \\
0 \\
1\end{array}$ & $\begin{array}{l}* \\
0 \\
0 \\
0 \\
1\end{array}$ & 호 & 葲 \\
\hline & & Elkerülés & 卷 & $\begin{array}{l}\text { t' } \\
\text { Oे }\end{array}$ & $\stackrel{20}{O}$ & $\begin{array}{l}\stackrel{*}{*} \\
\stackrel{7}{\sigma} \\
\sigma\end{array}$ & $\begin{array}{l}\stackrel{*}{*} \\
\stackrel{*}{7} \\
\stackrel{0}{0} \\
1\end{array}$ & $\begin{array}{l}\stackrel{*}{*} \\
\stackrel{*}{*} \\
\stackrel{2}{0} \\
1\end{array}$ & $\begin{array}{l}5 \\
0 \\
0\end{array}$ & $\begin{array}{l}\text { *. } \\
\stackrel{*}{N} \\
\stackrel{0}{0}\end{array}$ \\
\hline & \multirow{2}{*}{$\stackrel{\tilde{2}}{<}$} & Szorongás & 今o & $\begin{array}{l}3 \\
0 \\
0 \\
1\end{array}$ & $\begin{array}{l}\sigma \\
8 \\
0\end{array}$ & 今ે & $\begin{array}{l}\text { Tे } \\
0 \\
0 \\
1\end{array}$ & $\begin{array}{l}\text { J } \\
0 \\
0 \\
1\end{array}$ & $\begin{array}{l}8 \\
0 \\
0\end{array}$ & 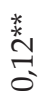 \\
\hline & & Elkerülés & 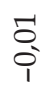 & $\begin{array}{l}\text { Lo } \\
\stackrel{0}{0} \\
0 \\
1\end{array}$ & $\stackrel{10}{\circ}$ & $\begin{array}{l}8 \\
0 \\
0 \\
1\end{array}$ & $\begin{array}{l}* \\
0 \\
0 \\
0 \\
1 \\
1\end{array}$ & $\begin{array}{l}\text { *a } \\
\text { Oे } \\
\text { i } \\
1\end{array}$ & O̊. & 오 \\
\hline & \multirow{2}{*}{$\sum^{\pi}$} & Szorongás & $\begin{array}{l}8 \\
0 \\
0\end{array}$ & 's & $\begin{array}{l}\text { ô } \\
\text { o } \\
\text { - }\end{array}$ & $\stackrel{l}{\circ}$ & $\begin{array}{l}* \\
0 \\
0 \\
0 \\
1 \\
1\end{array}$ & $\begin{array}{l}8 \\
0 \\
0 \\
1\end{array}$ & 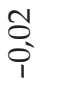 & $\stackrel{2}{2}$ \\
\hline & & Elkerülés & 象 & 占 & $\begin{array}{l}\text { ô } \\
\text { o } \\
0\end{array}$ & $\begin{array}{l}\text { \& } \\
0 \\
0\end{array}$ & $\begin{array}{l}* \\
0 \\
0 \\
0 \\
1\end{array}$ & $\begin{array}{l}8 \\
8 \\
0 \\
1\end{array}$ & 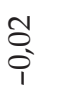 & $\begin{array}{l}\text { 유 } \\
\text { O̊ } \\
0\end{array}$ \\
\hline \multirow{2}{*}{ 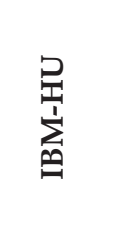 } & \multicolumn{2}{|r|}{ Kontro } & $\begin{array}{l}\text { * } \\
\stackrel{k}{N} \\
\delta\end{array}$ & \begin{tabular}{l}
$*$ \\
\multirow{2}{*}{} \\
0 \\
0 \\
0
\end{tabular} & 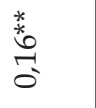 & 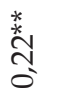 & $\begin{array}{l}\text { * } \\
\stackrel{7}{-} \\
\stackrel{1}{1} \\
\end{array}$ & $\begin{array}{l}0 \\
0 \\
0 \\
1\end{array}$ & $\begin{array}{l}0 \\
0 \\
0 \\
1\end{array}$ & 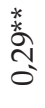 \\
\hline & \multicolumn{2}{|c|}{ Gondoskodás } & $\begin{array}{l}\text { * } \\
\cdots \\
\infty \\
0 \\
0 \\
1\end{array}$ & \begin{tabular}{l}
$* 0$ \\
\multirow{2}{*}{} \\
0 \\
0 \\
1
\end{tabular} & 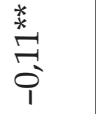 & $\begin{array}{l}\text { 苟 } \\
\text { Oे } \\
0 \\
1\end{array}$ & 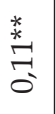 & 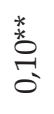 & $\begin{array}{l}\stackrel{2}{O} \\
0 \\
0\end{array}$ & 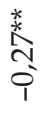 \\
\hline & \multicolumn{2}{|c|}{ SKÁLANEVEK } & 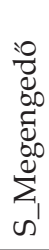 & 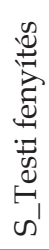 & 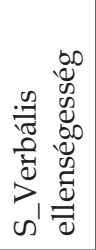 & 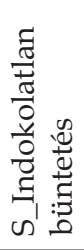 & 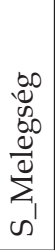 & $\begin{array}{l}\frac{\infty}{d} \\
\sum_{i=1}^{\infty} \\
\omega^{\prime}\end{array}$ & 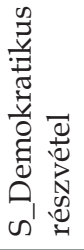 & 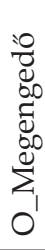 \\
\hline
\end{tabular}




\begin{tabular}{|c|c|c|c|c|c|c|c|c|}
\hline \multirow{3}{*}{$\stackrel{\infty}{\varrho}$} & \multirow{3}{*}{ 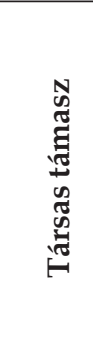 } & Instrumentális & 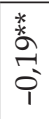 & 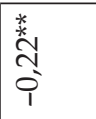 & 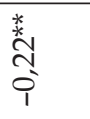 & $\begin{array}{l}* \\
* \\
F \\
0\end{array}$ & \begin{tabular}{l}
$*$ \\
\multirow{2}{*}{} \\
$\overbrace{0}^{2}$ \\
0
\end{tabular} & \begin{tabular}{l}
$*$ \\
\multirow{2}{*}{} \\
$\mathfrak{a}^{2}$ \\
0
\end{tabular} \\
\hline & & $\begin{array}{l}\text { Pozitív szociális } \\
\text { interakció. }\end{array}$ & 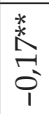 & 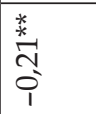 & 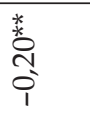 & 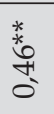 & 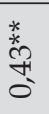 & 褛 \\
\hline & & $\begin{array}{c}\text { Érzelmi- } \\
\text { információs t. }\end{array}$ & 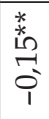 & 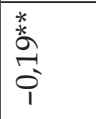 & 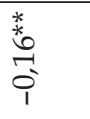 & 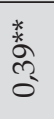 & 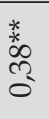 & \begin{tabular}{l} 
* \\
\multirow{2}{*}{} \\
$\overbrace{}^{2}$ \\
0
\end{tabular} \\
\hline ZUNG & \multicolumn{2}{|c|}{ Depresszió } & 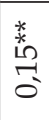 & 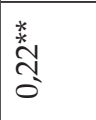 & 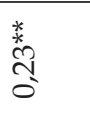 & 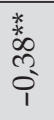 & 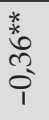 & 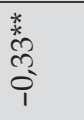 \\
\hline STAI-T & \multicolumn{2}{|c|}{ Vonásszorongás } & 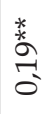 & 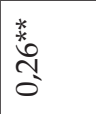 & 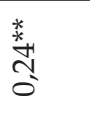 & 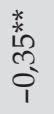 & 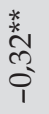 & 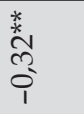 \\
\hline RAS-H & \multicolumn{2}{|c|}{$\begin{array}{l}\text { Párkapcsolati } \\
\text { elégedettség }\end{array}$} & 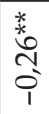 & 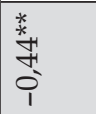 & 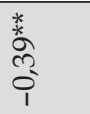 & $\begin{array}{l} \\
* \\
0 \\
1 \\
1 \\
0 \\
0\end{array}$ & 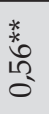 & $\begin{array}{l}* \\
* \\
\vdots \\
0 \\
0\end{array}$ \\
\hline \multirow{6}{*}{ 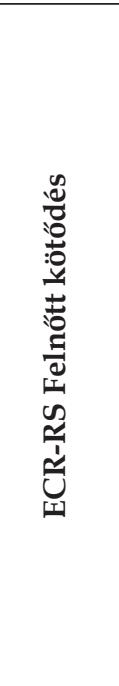 } & \multirow{2}{*}{ 气ี } & Szorongás & ڤે & 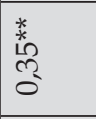 & 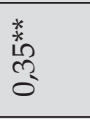 & $\begin{array}{l}* \\
* \\
\infty \\
0 \\
0 \\
0 \\
1\end{array}$ & 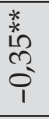 & 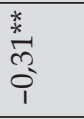 \\
\hline & & Elkerülés & 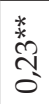 & 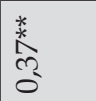 & 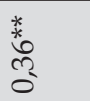 & $\begin{array}{l}x^{*} \\
\hat{k}^{*} \\
0 \\
0 \\
1\end{array}$ & 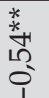 & 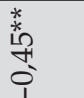 \\
\hline & \multirow{2}{*}{$\frac{\tilde{\alpha}}{4}$} & Szorongás & 党 & $\begin{array}{l}* \\
\infty \\
0 \\
0 \\
0\end{array}$ & 菼 & 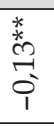 & $\begin{array}{l}\stackrel{*}{*} \\
\stackrel{*}{*} \\
\stackrel{5}{1} \\
1\end{array}$ & 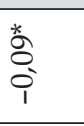 \\
\hline & & Elkerülés & ô & O⿱ & $\begin{array}{l}5 \\
0 \\
0 \\
1\end{array}$ & 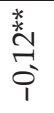 & 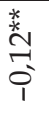 & $\begin{array}{l}\text { k } \\
0 \\
0 \\
0 \\
1\end{array}$ \\
\hline & \multirow{2}{*}{$\stackrel{\pi}{\gtrless}$} & Szorongás & $\stackrel{*}{*}$ & 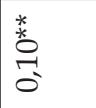 & 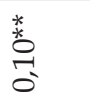 & 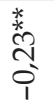 & 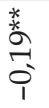 & \begin{tabular}{l} 
* \\
\multirow{2}{*}{} \\
$\stackrel{2}{0}$ \\
1
\end{tabular} \\
\hline & & Elkerülés & \begin{tabular}{l}
$*$ \\
\multirow{2}{*}{0} \\
$\stackrel{0}{0}$ \\
0
\end{tabular} & \begin{tabular}{l}
$*$ \\
$*$ \\
\multirow{2}{*}{} \\
$\stackrel{1}{0}$ \\
0
\end{tabular} & 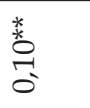 & 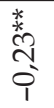 & 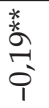 & 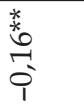 \\
\hline \multirow{2}{*}{ 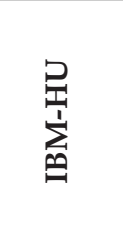 } & & Kontroll & 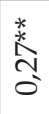 & 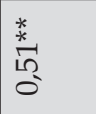 & $\begin{array}{l}*^{*} \\
\stackrel{*}{*} \\
0\end{array}$ & 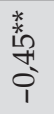 & 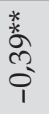 & $\begin{array}{l}\text { * } \\
0 \\
\infty \\
0 \\
0 \\
1\end{array}$ \\
\hline & & ndoskodás & \begin{tabular}{l}
${ }^{*}$ \\
\multirow{2}{*}{} \\
$\vdots$ \\
0 \\
1
\end{tabular} & 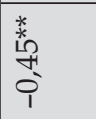 & 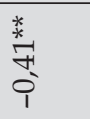 & 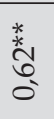 & \begin{tabular}{l}
$\frac{*}{*}$ \\
\multirow{6}{*}{} \\
0
\end{tabular} & $\begin{array}{l}\text { * } \\
\text { * } \\
\text { مै } \\
0\end{array}$ \\
\hline \multicolumn{3}{|c|}{ SKÁLANEVEK } & 胥 & 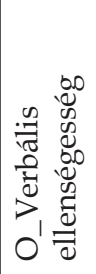 & 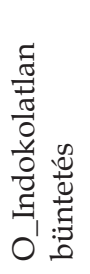 & $\begin{array}{l}\infty \\
w^{\infty} \\
0 \\
0 \\
\frac{0}{0} \\
\sum_{1}^{\infty} \\
0\end{array}$ & 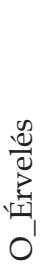 & 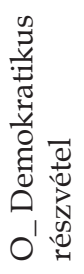 \\
\hline
\end{tabular}

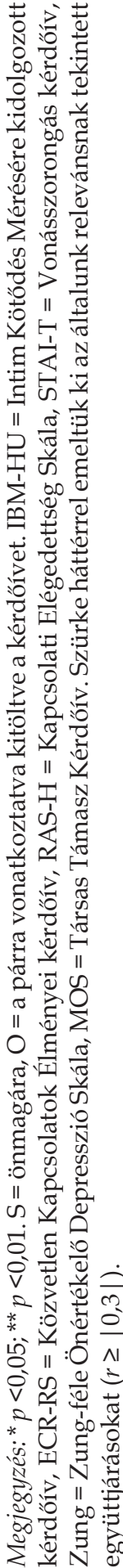




\section{Megbeszélés}

Napjainkban a nukleáris családforma a legelterjedtebb, ahol a szülőkre hárul minden olyan szerep és feladat, amely a többgenerációs és kiterjedtebb családokban megoszlik. Világszerte elfogadottnak tekinthető, hogy a szülők felelőssége a szülői nevelési célok megvalósítása: életben tartani a gyermeket; olyan készségek elsajátítását biztosítani a számára, amelyek gazdaságilag eredményes felnőtté teszik őt; és garantálni a csoportra jellemző kulturális értékek elsajátítását (Le Vine, 1988, id. Cole \& Cole, 2006). Magyarországon 1990 és 2016 között megközelítőleg 70\%-ot tett ki azoknak a háztartásoknak az aránya, ahol a 19 év alatti gyermekkel rendelkező szülők párkapcsolatban éltek, de a háztartásban nem éltek felmenó rokonok, azaz a nukleáris családban nevelték a gyermekeiket (Monostori \& Murinkó, 2018).

A felelősségvállalással párhuzamosan csökkent a szülői tekintély, Harari (2018) szerint egyenesen visszaszorulóban van. „A fiatalok egyre kevésbé engedelmeskednek az idősebbeknek, viszont a szülők felelősek mindenért, ami a gyermekük életében elromlik" (Harari, 2018, 323. o.). A szülők igyekeznek a nevelési stílusukat az adott kultúra által elfogadotthoz igazítani, próbálnak megfelelni a társadalmi elvárásoknak, hiszen egyrészt csak így érezhetik magukat kompetensnek, másrészt pedig bizonyos keretek között a kötelességszegés (pl. a nem megfelelő bánásmód, az iskoláztatás elmaradása stb.) szankciót (pl. szabálysértési eljárást) von maga után, szélsőséges esetben pedig akár ki is emelhetik a gyermeket a családból.

711 fős, keresztmetszeti kérdőíves vizsgálatunkban konfirmatív faktorelemzéssel ellenőriztük a Robinson és munkatársai (2001) által kialakított 32 tételes, a szülói nevelői stílust önmagára és párjára vonatkoztatva mérő Parenting Styles and Dimensions Questionnaire (PSDQ) kérdőív elméleti struktúráját, amelynek eredményeként az önészleletre és párészleletre vonatkozó kérdőívek struktúrája egyaránt megbízhatónak bizonyult. A magyar nyelvú változatban (Szülői Nevelői Stílus Kérdőív, PSDQ-HU), 7 faktor (alskála) jelenik meg, amelyeket besorolhatunk a 3 nevelöi stílusba. Az alskálák belső reliabilitása is megfelelő, a nemzetközi tapasztalatokhoz hasonlóan a megengedő (permisszív) skála Cronbach- $\alpha$ értéke a legalacsonyabb, így részben elfogadjuk Martins és munkatársai (2018) magyarázatát, miszerint a skála túl kevés tételt tartalmaz. Ugyanakkor bennünk is felmerült annak lehetősége, hogy Williams és munkatársainak (2009) van igaza: a tartalma alapján ez az alskála nem is biztos, hogy az engedékenységet méri, hanem valójában a szülő́k nevelői inkozisztenciáját. Saját vizsgálatunk eredményei arra is rávilágítanak, hogy a Másikra vonatkoztatott percepciót mérve az alskálák reliabilitása minden alskála esetében magasabb, ami azt jelenti, hogy a párra vonatkozó percepció mérése megbízhatóbb, mint a saját magunkra vonatkoztatott szülői nevelői stílus mérése. 
Eredményeink szerint az alskálák az önmagára és a társa szülői nevelői stílusának percepciójára vonatkoztatva számos esetben együttjárásokat mutatnak.

Minél megengedőbbnek észleli önmagát szülőként valaki, az együtt jár azzal, hogy verbálisan annál ellenségesebbnek lássa önmagát, a párját pedig önmagához hasonlóan szintén megengedőnek, verbálisan ellenségesnek és ráadásul indokolatlanul büntetőnek észlelje a gyermekükkel szemben. Azonban ahogy azt már korábban említettük, a skála instabilitása miatt (Martins és munkatársai, 2018) nem is igazán a megengedő, hanem inkább egy kevésbé bevonódó szülői magatartás az, ami együtt jár a verbális ellenségességgel.

A testi fenyités alkalmazásával együtt jár a verbális ellenségesség és indokolatlan büntetés, valamint a párjának önmagához hasonló észlelése, egy erősebb korrelációt mutatva. Ez a hasonlóság az önmaga és társa percepciójában egy keményebb, esetlegesen akár bántalmazó magatartásra enged következtetni, ahol a két szülő meglehetősen hasonló módon viszonyulhat a gyermekhez. Számos kérdést felvet ez az összefüggés, hiszen elgondolkodtató, hogy vajon hogyan alakulnak a gyakorlatban ezen szülői megnyilvánulások? Egyszerre történik-e mindkét szülő részéról a fenyítés, vagy a szülők felváltva fenyítik, büntetik a gyermeket, esetleg „megvédik” őt egymástól? Ha ez utóbbi jelenne meg, az teljesen eltéró családi dinamikát eredményezhet.

Ha valaki magát szülőként verbálisan ellenségesnek éli meg, akkor az együtt jár azzal, hogy indokolatlanul alkalmaz büntetéseket, valamint korrelál azzal, hogy a társát is verbálisan ellenségesnek észleli, indokolatlanul büntetőnek, kevésbé meleg, érvelő és demokratikus attitúdűnek.

Úgy túnik, hogy az indokolatlan büntetőnek megélt saját attitúddel együtt jár, hogy a párját is hasonlónak éli meg az illető; továbbá, ha a párját indokolatlanul büntetőnek találja, akkor egyben kevéssé meleg, érvelő és demokratikus attitúdöt észlel a részéról.

A saját magát meleg nevelooi stílussal jellemző szülőséggel együtt jár az érveló és demokratikus részvétel tulajdonítása, ahogy a pár melegséggel teli attitúdjének észlelése is szorosan együtt jár az ő érvelő és demokratikus stílusának észlelésével.

Végül minél érvelóbbnek tartja valaki szülőként magát, az együtt jár azzal, hogy annál demokratikusabb részvételt tulajdonítson saját magának. Ha pedig érvelőnek látja a párját, akkor ez meglehetősen erőteljesen kapcsolódik ahhoz az észleletéhez, hogy a párja demokratikus részvételt mutat a gyermekük nevelésével kapcsolatban.

A szülői nevelői stílus bizonyos aspektusai eltéréseket mutatnak néhány szociodemográfiai változó mentén, bár ezek hatásmértéke nem minden esetben éri el a matematikailag relevánsnak tekinthetőt. 
Nemi különbségre utal, hogy a nők önmagukat szignifikánsan kevésbé látják indokolatlanul büntetőnek, mint a férfiak önmagukat. Melegebbnek, érvelést gyakrabban alkalmazónak, demokratikusabbnak észlelik magukat az anyák, mint az apák, és ezek az eredmények összecsengenek a párjuk észlelésével, hiszen az apák az anyákat szignifikánsan melegebbnek, érvelóbbnek és demokratikusabban nevelőknek látják, mint az anyák az apákat. Mindezek alapján kijelenthetjük, hogy az anyák melegebb, érvelő és demokratikusabb nevelői stílust alkalmaznak, mint az apák, a saját és az apai megítélés szerint is. Ez az eredmény talán a kulturálisan beágyazott nemiszerep-viselkedéseknek, illetve -elvárásoknak is köszönhetó (Hofstede, 2011), hiszen az anyák eleve több időt töltenek még mindig a gyermekek nevelésével (Garcia Roman \& Cortina, 2015), valamint az anyák feladatuknak tekintik az érzelmi biztonság és a pozitív légkör biztosítását a családban, amelynek szerves része a gyermekhez való viszonyulás. Az apák a szülői tekintély képviselőiként valószínúleg kevésbé érzik szükségesnek az indoklást a nevelői gyakorlatukban, bár ezt az anyák észlelése nem támasztja alá.

A szülő saját szocializációja szempontjából különbség mutatkozik a testvérrel rendelkező és nem rendelkező szülők nevelői stílusában. Úgy túnik, hogy az egykeként felnövekedő szülőkben erőteljesebben jelenik meg a gyermekük iránt egy melegebb szülői attitúd és a párjukat is melegebb, érvelő magatartásúnak észlelik, mint azok, akiknek volt gyermekként testvérkapcsolatuk. A jelenség magyarázatára tudomásunk szerint nem állnak rendelkezésre vizsgálati eredmények, ezért egyrészt feltételezhetünk egy gyermekkori érzelmi hiányt, amit a szülőségével próbál felülírni, hiszen a testvérhelyzet az esetleges testvérféltékenység és rivalizáció mellett nagyon sok szeretet- és kompetenciaforrást is kínál; másrészt az is elképzelhető, hogy a saját gyermekkori élményei annyira pozitívak, a maximális odafigyelést, melegséget, elfogadást élt át a szülője/szülei részéről, amelynek a továbbadása természetes a számára. Amennyiben a szülei nem maradtak adósak a szeretettel, pozitív jogosultságot érez, azaz, a kapcsolati etikának megfelelően, azt adja tovább, amit ő is kapott, ahogy azt a kontextuális családterápia megalkotója, Böszörményi Nagy Iván tételezi (Meiden, Noordegraaf, \& Ewijk, 2017). Ezek a feltételezések azonban mindenképpen további vizsgálatot igényelnek.

A lakóhely szerint a "tradicionálisabb" nevelési módszerek - így a fizikai fenyítés alkalmazása - vidéken erőteljesebben vannak jelen (Scanzoni \& Arnett, 1987), mint az urbánusabb településeken. A demokratikus részvételt a nevelésben elterjedtebbnek találtuk a fóvárosban élőknél, mint a városban élőknél, de a falun élőkkel összehasonlítva nincs szignifikáns különbség, s ezen eltérések hatásértéke nagyon gyenge. Így önmagában a lakóhelyet nem tekinthetjük egy nevelési stílus szempontjából meghatározó tényezőnek, annak ellenére, hogy korábban találtak nevelésbeli eltéréseket a lakó- 
hely szerint. Például Coleman és Gangong (1989) kutatásuk alapján arra a következtetésre jutottak, hogy a városi szülők nagyobb hangsúlyt fektetnek gyermekeik emocionális, intellektuális készségeinek a fejlesztésére, mint a vidéken élők, ahol a szociális készségek a hangsúlyosabbak.

A nemzetközi kutatások eredményei szerint a gyermeknevelésről vallott nézetekre hatással lehet az iskolázottság, így Waylen és Stewart-Brown (2010) eredményei szerint a magasabban iskolázott anyák több gyermekneveléssel, a gyermek fejlődésével kapcsolatos tudásról számoltak be. Blair és munkatársai (1994) a magasabb végzettségú apáknál mutattak ki pozitívabb elköteleződést az iskoláskorú gyermekeik felé. A magasabb iskolai végzettség segítheti olyan készségek kialakítását és lehetőségek megteremtését, amivel például könnyebben hozzáférnek a kurrens szakirodalomhoz, illetve nevelési elakadások esetében a szaksegítség igénybevételéhez (Pickard \& Ingersoll, 2015). Az iskolázottság és a nevelési stílus összefüggéseit vizsgálva bár azt találtuk, hogy a verbális büntetést, szidalmazást a magasan képzett szülők gyakrabban alkalmazták, az indokolatlan büntetéssel pedig leginkább az alacsonyabb iskolai végzettséggel rendelkezők élnek, a magasabb végzettségúekhez képest szignifikánsan gyakrabban, a hatásértékek alacsony volta miatt ezen eredmények további ellenőrzésre szorulnak. A megbízhatóbb eredményekért a jövóbeni kutatásoknál a minta reprezentativitására nagyobb hangsúlyt kell fektetni, hiszen alacsony iskolázottsággal rendelkező szülő alig fordult elő a mintánkban, mindössze 3,5\% volt, aki nem rendelkezett érettségivel. Emellett, az önbeszámoló kérdőív kitöltésénél nem tekinthetünk el a szülőknek a társadalmi kívánatosságnak való megfelelés igényétól sem, ami szintén torzíthat az eredményeken, ám jelen vizsgálatban ezt a tényezőt nem kontrolláltuk.

Azt találtuk, hogy a családi állapot szerint szignifikáns, releváns hatásmértékú különbség látható a nevelói stílusban a házasságban / élettársi kapcsolatban élők és az elváltak között, a párészlelet szempontjából. Az elváltak a gyermeket nevelő másik szülőt kevésbé melegnek, érvelőnek és demokratikus résztvevőnek élik meg. Ez az eredmény több kérdést vet fel, mint amire válaszolni tudunk az adatok alapján, hiszen azt mutatja, hogy a gyermek nevelésében részt vevő másik szülőt önmagához képest szignifikánsan kedvezőtlenebbül ítéli meg a válaszoló. Ez a tény magyarázható válás esetén a szülők között még fennálló feszültséggel, le nem zárult érzelmi válási folyamattal, ami gyakran jár indulatokkal, a másik fél hibáztatásával, illetve valóban kevésbé involválódott szülói magatartással is, attól függően például, hogy kivel él a gyermek (Kaslow, 1988). A feltételezéseink további vizsgálatot igényelnek, pontosabb, a populációra jellemző adatgyújtéssel, amely az általunk nem kontrollált változók bevonását is szükségessé teszi, például: mióta áll fenn az adott családi állapot, a gyermek elhelyezése, a különéló szülővel való kapcsolattartás formája, minősége. 
Megvizsgáltuk a szülői nevelői stílus összefüggéseit a párkapcsolati intimitás két aspektusával, nevezetesen a gondoskodással és kontrollal is. Az észlelt gondoskodás kedvező a szülői nevelői stílus szempontjából is, hiszen minél gondoskodóbbnak észleli valaki a párját, annál melegebb, érvelőbb és demokratikusabb részvételúnek tapasztalja szülőként is, annál kevésbé látja verbálisan ellenségesnek és indokolatlanul büntetőnek a gyermekükkel kapcsolatban, és az összefüggés fordítva is igaz. A kontroll fokozott észlelésével azonban együtt nő a verbális ellenségesség és indokolatlan büntetés észlelete, annak csökkenésével pedig nő a melegség, az érvelés és a demokratikus részvétel percepciója és fordítva. Ezek az összefüggések arra engednek következtetni, hogy minél gondoskodóbbnak tapasztalja a párkapcsolatában a társát a szülő, annál pozitívabbnak észleli ôt szülőként is, és minél kontrollálóbbnak éli meg ôt párkapcsolati szinten, annál kevésbé pozitív a tapasztalata róla a szülői minőségében. Ez természetesen nem jelent ok-okozati összefüggést, de elgondolkodtató a párkapcsolati minőség és szülői múködés ilyenfajta együttjárása. Eredményünk alátámasztani látszik azokat a korábbi kutatási eredményeket, ahol a párkapcsolati minőség szülőségre gyakorolt hatását igazolták, így a kapcsolati harmónia és az autoritatív nevelési stílus pozitív korrelációját, valamint az autoriter és permisszív stílusok negatív együttjárását a párkapcsolati harmóniával (Sevinc \& Garip, 2010).

Úgy túnik továbbá, hogy a párhoz való felnőtt kötődés fontos szerepet tölt be a szülői nevelői stílus alakulásában. Nanu és Nijloveanu (2015) szignifikáns együttjárást mértek a felnőtt párkapcsolati kötődés és az autoritatív szülői nevelői stílus között. Saját eredményeink szerint is, minél biztonságosabb a kötődés a párral, annál kedvezóbb a társ szülói minőségének az észlelete. Mindez arra utalhat, hogy a biztonságosan kötődő párok szülóségükben is a szeretetteljesebb viszonyulást tudják megvalósítani, illetve minél inkább bizonytalan a kötődésük, annál kevésbé észlelik egymást szülőként is érzelmileg melegnek, türelmesnek, aki érvel, illetve megindokolja, hogy mit miért tesz, esetleg bevonja a gyermeket, figyelembe véve annak véleményét; inkább látják egymást verbálisan agresszívnek, szidalmazónak, aki nem indokolja a büntetést a gyermekük felé. A párkapcsolatban jelen lévő feszültség rányomja bélyegét a szülőnek a gyermekkel való kapcsolatára is, bár ennek mértéke csak a szülótárs viselkedésének megítélésénél éri el a szakmailag is releváns mértéket (a saját szülői nevelői stílus megítélésénél nem), ami azt jelenti, hogy ha a párommal kapcsolatban szorongok, illetve elkerülő magatartást tanúsítok, akkor hajlamos vagyok őt szülőként is kevésbé pozitívan látni. A felnőtt párkapcsolati kötődés jelentőségére hívják fel a figyelmet, bár a gyermekneveléssel való kapcsolatára nem térnek ki Lussler, Sabourin és Turgeon (1997), akik kutatásukban azt találták, hogy az elkerülő/ambivalens kötődésről beszámoló férjek és feleségek több házassági stresszt éltek meg, mint a biztonságosan kötődő házastársak. 
Összefüggést találtunk a párkapcsolati elégedettség és a szülői nevelői stílus között is. Eredményeink szerint minél elégedettebb valaki a párkapcsolatával, annál kedvezőbbnek ítéli meg a párja szülői nevelői magatartását, érzelmileg melegebbnek, érvelóbbnek és demokratikusabbnak találja, kevésbé szidalmazónak, ellenségesnek verbálisan és indokolatlanul büntetőnek. Mivel együttjárásról beszélünk, így az is érvényes, hogy minél kedvezőbbnek ítéli meg valaki szülőként a párját, annál elégedettebb a párkapcsolatával. Konkrét kutatási eredmények nincsenek a párkapcsolati elégedettség és nevelói stílusok kapcsolatáról, így saját vizsgálatunk ebből a szempontból újdonságnak számít. Ugyanakkor ismert, hogy a szülók közötti eltérő nevelői stílusok több párkapcsolati konfliktussal járnak és a párkapcsolati konfliktusok és a gyermekek viselkedési problémái szignifikáns együttjárást mutatnak (Thorvardarson \& Winsler, 2016).

A vizsgált pszichológiai jellemzők, mint vonásszorongás, depresszió és társas támasz is mutatnak összefüggéseket a szülői nevelői stílus bizonyos aspektusaival.

A szorongás fokozott volta nem kedvez a másik, azaz a pár szülői múködése megítélésének a melegség, az érvelés és a demokratikus részvétel tekintetében, illetve minél kevésbé pozitívan ítéli meg valaki szülőként a párját, annál inkább szorong és fordítva.

Az ok-okozati összefüggések megállapítására nem alkalmas az általunk alkalmazott keresztmetszeti vizsgálati elrendezés, de eredményeink fényében az alátámasztást nyert, hogy a depresszió skálán elért minél magasabb pont a pár kedvezőtlenebb szülői nevelői stílusának észlelésével jár együtt: alacsonyabb melegséggel, érveléssel és demokratikus részvétellel. Természetesen az összefüggés fordítva is érvényes: a pár észlelt melegsége, érvelése és demokratikus részvétele a gyermeknevelésben annál alacsonyabb, minél magasabb az egyén depressziót becslő skálán elért pontja. Ez összhangban van azon kutatási eredményekkel, amelyek szerint a depressziós anyák hajlamosabbak rosszabb házastársi minőségről számot adni (Heflin \& Iceland, 2009), és a környezetük negatívabb észlelése miatt párjuk negatív üzeneteit hangsúlyosabban érzékelik, mint a pozitívokat (Kowalik \& Gotlib, 1987), valamint kevesebb pozitív, több negatív megnyilvánulást mutatnak a gyermekük felé, kevésbé empatikusak és érzelmi válaszkészségük alacsonyabb (Feng, Shaw, Skuban, \& Lane, 2007; Lovejoy, Graczyk, O'Hare, \& Neuman, 2000).

Annak ellenére, hogy vizsgálatunkban csak az egyik fél szorongás- és depresszióértékét mértük, az eredmények nem elhanyagolhatóak, hiszen a család rendszerszemléletú megközelítése szerint kölcsönös függóség (interdependencia) van a házasság/párkapcsolat és a szülő-gyermek kapcsolat között a családon belül. A nem kielégítő szülő-gyermek kapcsolatok gyakran a distresszt megélő párkapcsolatokban alakulnak ki, mert az egyik családtag vonásai hatással vannak a másikéra (Cox \& Paley, 2003). 
A pár szülői nevelői stílusának észlelése a melegség, érvelés és demokratikus részvétel dimenziókban annál kedvezőbb, minél erősebb társas támogatást észlel valaki, azaz minél több érzelmi és információs támaszra számíthat, továbbá minél több pozitív társas interakciót és instrumentális támaszt észlel. Monostori és Murinkó (2018) tanulmánya szerint Magyarországon a 25 év alatti gyermekkel élő háztartásoknak csak alig egytizede tartozik a háromgenerációs háztartások közé. Így a napi szinten elérhető nagyszülői támogatás hazánkban meglehetősen limitált, és a szülők részéről szervezést, illetve külön energiát igénylő folyamat a támogatás hozzáférhetővé tétele. Eredményeink felhívják a figyelmet a társas támasz jelentőségére, hiszen az elérhető társas támasz nagyban csökkentheti azt a terhet, amely annak hiányában a szülőpárra hárul, valószínúleg megterhelve a kapcsolatot, amelynek minősége viszont - amint azt fentebb láthattuk -, komoly szerepet játszik a nevelői stílus alakulásában és a szülőség megélésében.

A szülői nevelói stílusok vizsgálata kiemelten fontos terület, hiszen a gyermekekre gyakorolt hatásai generációkon keresztül befolyásolják a következő nemzedék családdal, illetve gyermekneveléssel kapcsolatos attitúdjét. A szülők gyakran öntudatlanul örökítik át a következő generációnak, meghatározva az átadott értékeket, normákat és a családi kommunikációt. A kiegyensúlyozott párkapcsolat és az időnkénti konfliktusok ellenére is jól múködő család megfelelő mintát közvetít a nevelés során a gyermekek számára, míg diszfunkcionálisan múködő családok mintái gyakran híján vannak annak a társas támogatásnak, ami a biztonságot, elfogadást és a szeretetteljes empátiát nyújtja. Meg kell említenünk a manapság egyre inkább az érdeklődés homlokterébe kerülő családon belüli bántalmazás/erőszak témáját is, amelyról az ENSZ Kábítószer és Búnügyi Hivatala közöl riasztó adatokat. A Földön naponta 137 nő hal meg családi/párkapcsolati erőszak következtében (UNODC, 2018). A családon belüli erőszak témáját áttekintve megállapítható, hogy mind az áldozatok, mind pedig az elkövetők diszfunkcionális családban nevelkedtek. Úgy gondoljuk, hogy a PSDQ-HU kérdőív révén feltárt összefüggések megismerése a prevenciós eljárásokhoz is segítséget nyújthat.

\section{Korlátok}

A vizsgálatban nem párokat vizsgáltunk, hanem gyermeket neveló anyákat és apákat, így a konkrét párkapcsolati dinamikára vonatkozó következtetéseket csak az egyik fél észlelése alapján tudunk levonni, ami meglehetősen egyoldalú. A minta reprezentativitásának hiányával is számolnunk kell, így 
például a nemi eltolódással is, hiszen lényegesen kevesebb apa vett részt a vizsgálatban, mint anya. Az eredményeink általánosíthatóságát korlátozza az a tény is, hogy az adatgyújtés módja nem tette lehetővé, hogy olyan társadalmi rétegekhez is eljusson nagyobb számban a kérdőív, akik nem rendelkeznek elektronikus hozzáféréssel, vagy nem mozognak otthonosan az online világban. A társadalmi kívánatosságnak való megfelelés szúrése is indokolt lett volna, hiszen meglehetósen kényes téma a gyermekek fegyelmezésének kérdése, s bár az anonimitás garantált volt, az önmagunkkal való szembenézés, a saját múködés és a vágyott közötti esetleges diszkrepanciával való szembesülés nem könnyen vállalható.

\section{7. Összegzés kitekintés}

Összességében a nem, a családi állapot, az iskolázottság, a lakóhely, valamint az, hogy valaki egykeként nó-e fel, szerepet játszhat a szülői nevelői stílusának alakulásában. A párkapcsolati intimitás, a felnőtt kötődés biztonsága, a párkapcsolattal való elégedettség szintén együtt jár azzal, hogy milyen szülőnek észleli valaki a párját. A vonásszorongás skálán és a Zungféle depresszió kérdőíven elért pontok a pár negatívabb szülőként való észlelésével mutatnak együttjárást. A minél erősebb társas támasz észlelete egy pozitívabb szülői attitúd percepciójával jár együtt, a párra vonatkoztatva. A saját magára vonatkoztatott szülői nevelői stílus nem mutat szignifikáns összefüggést egyetlen vizsgált skálaváltozóval sem. Jelen vizsgálat eredményei a limitációk ellenére azt bizonyítják, hogy a PSDQ-HU kérdőív stabil faktorstruktúrával és hasonló megbízhatósággal mér, mint a nemzetközi szakirodalomban, s ezáltal egy lehetséges mérőeszköze a szülői nevelői stílusnak. A mérőeszköz az általunk feltárt összefüggések alapján kiemelten a másik, azaz a párja nevelői stílusának megítélésére alkalmazható nagy megbízhatósággal.

\section{Irodalom}

Adam, E.K., Gunnar, M.R., \& Tanaka, A. (2004). Adult Attachment, Parent Emotion, and Observed Parenting Behavior: Mediator and Moderator Models. Child Development, 75(1), 110-122.

Alt, F. (1995). Előszó. In: C.G. Jung, Gondolatok az apáról, az anyáról és a gyermekről (7). Budapest: Kossuth Könyvkiadó

Arafat Yasir, S.M. (2018). Validation of Bangla parenting style and dimension questionnaire. Global Psychiatry, 1(2), 95-107.

Barber, B.K. (1996). Parental psychological control: Revisiting a neglected construct. Child Development, 67(6), 3296-3319. 
Barber, B.K., Stolz, H.E., \& Olsen, J.A. (2005). Parental support, psychological control, and behavioral control: Assessing relevance across time, culture, and method. Monographs of the Society for Research in Child Development, 70, 1-137.

Baumrind, D. (1966). Effects of authoritative parental control on child behavior. Child Development, 37(4), 887-907.

Baumrind, D. (1968). Authoritarian vs. authoritative parental control. Adolescence, 3(11), 255-272.

Baumrind, D. (1971). Current Patterns of Parental Authority. Developmental Psychology Monograph, 4(1), 1-103.

Baumrind, D. (1989). Rearing competent children. In: W. Damon (Ed.). Child development today and tomorrow (349-378). San Francisco: Jossey-Boss

Baumrind, D. (1991). The influence of parenting style on adolescent competence and substance use. Journal of Early Adolescence, 11, 56-95.

Baumrind, D. (2012). Differentiating between confrontive and coercive kinds of parental power-assertive disciplinary practices. Human Development, 55, 35-51.

Baumrind, D. (2013). Authoritative parenting revisited: History and current status. In: R.E. Larzelere, A.S. Morris, \& A.W. Harrist (Eds.), Authoritative parenting: Synthesizing nurturance and discipline for optimal child development (11-34). Washington, DC: American Psychological Association Press

Baumrind, D., Larzelere, R.E., \& Owens, E.B. (2010). Effects of preschool parents' power assertive patterns and practices on adolescent development. Parenting: Science and Practice, 10, 157-201.

Becker, W.C. (1964). Consequences of different kinds of parental discipline. In: Hoffman, M. L., \& Hoffman, L. W. (Eds.). Review of child development research (169-208). New York: Russel Sage Foundation

Blair, S., Wenk, D., \& Hardesty, C. (1994). Marital quality and paternal involvement: interconnections of men's spousal and parental roles. Journal of Men's Studies, 2, 221-237.

Block, J.H. (1965). The child rearing practices report: A technique for evaluating parental socialization orientations. Berkeley, CA: University of California Institute of Human Development.

Block, J.H., Block, J., \& Morrison, A. (1981). Parental agreement-disagreement on childrearing orientations and gender-related personality correlates in children. Child Development, 52, 965-974.

Buri, J.R. (1991). Parental Authority Questionnaire. Journal of Personality Assessment, 57(1), 110-119.

Calzada, E.J., \& Eyberg, S.M. (2002). Self-reported parenting practices in Dominican and Puerto Rican mothers of young children. Journal of Clinical Child and Adolescent Psychology, 31, 354-363.

Caspi, A. (1998). Personality development across the life course. In: W. Damon \& N. Eisenberg (Eds.), Handbook of child psychology (5 ${ }^{\text {th }}$ ed.), Vol. 3: Social, emotional, and personality development (311-388). New York: Wiley.

Cole, M., \& Cole, S.R. (2006). Fejlődéslélektan. Osiris Kiadó, Budapest

Cowan, P.A., \& Cowan, C.P. (2009). Couple relationships: A missing link between adult attachment and children's outcomes. Attachment \& Human Development, 11(1), 1-4. DOI: 10.1080/14616730802500149

Cox, M.J., \& Paley, B. (2003). Understanding families as systems. Current Directions in Psychological Science, 12, 193-196.

Cox, M.J., Paley, B., \& Harter, K. (2001). Interparental conflict and parent-child relationships. In: J.H. Grych \& F.D. Fincham (Eds.), Interparental conflict and child development: Theory, research, and application (249-272). New York, NY; Cambridge University Press. DOI:10.1017/CBO9780511527838.011 
Darling, N., \& Steinberg, L. (1993). Parenting style as context: an integrative model. Psychological Bulletin, 113(3), 487-496.

Dekovic, M., Janssens, M.A.M. \& Gerris, J.R.M. (1991): Factor structure and construct validity of the Block Child Rearing Practices Report (CRPR): Psychological Assessment: The Journal of Consulting and Clinical Psychology, 3(2), 182-187.

Dix, T.H., \& Grusec, J.E. (1985). Parent attribution processes in child socialization. In: L. Sigel (Ed.). Parent belief systems: Their psychological consequences for children (201-233). Hillsdale, NJ: Erlbaum

DSM-IV (1997). A DSM-IV Diagnosztikai Kritériumai. Animula Kiadó, Budapest

Erát, D. (2019). A párkapcsolattal való elégedettség időbeli alakulása: lehetséges pályák és befolyásoló tényezők. Demográfia, 62(4), 347-384.

Erikson, H.E. (1968). The human life cycle. In: International Encyclopedia of Social Sciences (286-292). New York: Crowel-Colier

Eyberg, S., Nelson, M., \& Boggs, S. (2008). Evidence-based psychosocial treatment for children and adolescents with disruptive behavior. Journal of Clinical Child and Adolescent Psychology, 37, 215-237.

Feng, X., Shaw, D.S., Skuban, E.M., \& Lane, T. (2007). Emotional exchange in mother-child dyads: stability, mutual influence, and associations with maternal depression and child problem behavior. Journal of Family Psychology 21(4), 714-725.

Fili, E. (2016). Parenting styles and aggressive behaviour among preschool going children. International Journal of Academic Research and Reflection, 4(2), 1-8.

Fraley, R.C., Heffernan, M.E., Vicary, A.M., \& Brumbaugh, C.C. (2011). The Experiences in Close Relationships-Relationship Structures questionnaire: A method for assessing attachment orientations across relationships. Psyhological Assessment, 23, 615-625.

Fraley, C.R., Waller, N.G., \& Brennan, K.A. (2000). An item-response theory analysis of self-report measures of adult attachment. Journal of Personality and Social Psychology, 78, 350-365.

Fu, Y., Hou, X., Meng, H., Qiu, T., Qin, Q., \& Li, T. (2013). 1368 - Study on validity and reliability of the chinese version of parenting styles and dimensions questionnaire (PSDQ). European Psychiatry, 28(S1), 1. DOI: 10.1016/S0924-9338(13)76413-7

Garcia Roman, J., \& Cortina, C. (2015). Family time of couples with children: shortening gender differences in parenting? Review of Economics of the Household, 14(4), 921-940.

Gérecz, Á., \& Hadházi, É. (2014). Intimitás, a kötődés, szülői bánásmód és depresszió függvényében. In: M. Vassányi, J. Fülöp, \& Zs. Mirnics (Szerk.), Kapcsolatban - Istennel és emberrel. Pszichológiai és bölcsészeti tanulmányok (32-54). Budapest: L'Harmattan Kiadó

Gottman, J.M., \& Katz, L.F. (1989). Effects of marital discord on young children's peer interaction and health. Developmental Psychology, 25, 373-381.

Hadházi, É., \& Takács, Sz. (2019). Az Intim Kötődés Mérése (IBM-HU) kérdőív pszichometriai jellemzőinek bemutatása. Mentálhigiéné és Pszichoszomatika, 20(4), 351-390.

Harari, Y.N. (2018). Sapiens - Az emberiség rövid története. Budapest: Animus

Heflin, C.M., \& Iceland, J. (2009). Poverty, hardship, and depression. Social Science Quarterly, 90(5), 1051-1071.

Hendrick, S.S., Dicke, A., \& Hendrick, C. (1998). The Relationship Assessment Scale. Journal of Social and Personal Relationships, 15(1), 137-142.

Hofstede, G. (2011). Dimensionalizing cultures: The Hofstede Model in context. Online Readings in Psychology and Culture, 2(1).

Holden, G.W. (1995). Parental attitudes towards childrearing. In: M.H. Bornstein (Ed.), Handbook of parenting, Vol. 3. Status and social conditions of parenting (359-392). Lawrence Erlbaum Associates, Inc. 
Holt-Lunstad, J., \& Smith, T.B. (2012). Social relationships and mortality. Social \& Personality Psychology Compass, 6, 41-53.

Iyengar, S.S., \& Lepper, M.R. (2000). When choice is demotivating: Can one desire too much of a good thing? Journal of Personality and Social Psychology, 79, 995-1006.

Jantek, Gy., \& Vargha, A. (2016). A felnőtt kötődés korszerú mérési lehetősége: A közvetlen kapcsolatok élményei - kapcsolati struktúra (ECR-RS) kötődési kérdőív magyar adaptációja párkapcsolatban élő felnőtt személyeknél. Magyar Pszichológiai Szemle, 71(3), 447-470.

Karaer, Y., \& Akdemir, D. (2019). Parenting styles, perceived social support and emotion regulation in adolescents with internet addiction. Comprehensive Psychiatry. 92, 22-27.

Kaslow, F.W. (1988). The psychological dimension of divorce mediation. In: J. Folberg, \& A. Milne (Eds.). Divorce mediation: Theory and practice (83-103). New York: Guilford Press

Katz, L.E, \& Gottman, J.M. (1996). Spillover effects of marital conflict: In search of parenting and coparenting mechanisms. In: J.P. McHale \& P.A. Cowan (Eds.). New directions for child development: No. 74. Understanding how family level dynamics affect children's development: Studies of two-parent families (57-76). San Francisco: Jossey-Bass.

Kern, R.M., \& Jonyniene, J. (2012). Psychometric properties of the Lithuanian version of the parenting styles and dimensions questionnaire (PSDQ): Pilot Study. The Family Journal, 20, 205-214.

Kimble, A.B. (2014). The Parenting Styles and Dimensions Questionnaire: a reconceptualization and validation. Thesis Submitted to the Faculty of the Graduate College of the Oklahoma State University in partial fulfillment of the requirements for the Degree of Master of Science. July 2014, Stillwater, OK.

Kiss, N. (2008). A Baumrind-féle szülői nevelési stílus, kiskamaszok önértékelésére gyakorolt hatása. Fejlődéslélektan múhelymunka. Budapest: KRE, Pszichológiai Intézet

Kowalik, D.L., \& Gotlib, I.H. (1987). Depression and marital interaction: Concordance between intent and perception of communication. Journal of Abnormal Psychology, 96(2), 127-134.

Lavasani, M.G., Borhanzadeh, S., Afzali, L., \& Hejazi, E. (2011). The relationship between perceived parenting styles, social support with psychological well-being. Procedia- Social and Behavioral Sciences, 15, 1852-1856.

Le Vine, R.A. (1988). Human parental care: Universal goals, cultural strategies, individual behavior. In: R.A. Le Vine, P.M. Miller, \& M.M. West (Eds.). Parental behavior in diverse societies. New directions for child development, No: 40: The Jossey-Bass social and behavioral sciences series. San Francisco, CA: Jossey-Bass, Inc.

Lovejoy, M.C., Graczyk, P.A., O'Hare, E., \& Neuman, G., (2000). Maternal depression and parenting behavior: a meta-analytic review. Clinical Psychology Review, 20(5), 561-592.

Lussier, Y., Sabourin, S., \& Turgeon, C. (1997). Coping strategies as moderators of the relationship between attachment and marital adjustment. Journal of Social and Personal Relationships, 14, 777-791.

Maccoby, E.E., \& Martin, J.A. (1983) Socialization in the context of the family: Parent-child interaction. In: P.H. Mussen (Ed.). Handbook of child psychology (1-101). New York: Wiley

Martins, C., Ayala-Nunes L., Nunes, C., Pechorro, P., Costa, E., \& Matos, F. (2018). Confirmatory analysis of the Parenting Styles and Dimensions Questionnaire (PSDQ) short form in a portuguese sample. European Journal of Education and Psychology, 11(2), 77-91.

Martos, T., Sallay, V., Szabó, T., Lakatos, C., \& Tóth-Vajna, R. (2014). A Kapcsolati Elégedettség Skála magyar változatának (RAS-H) pszichometriai jellemzői. Mentálhigiéné és Pszichoszomatika, 15(3), 245-258. 
Meiden, J., Noordegraaf, M., \& Ewjik, H. (2017). Applying the paradigm of relational ethics into contextual therapy. Analyzing the practice of Ivan Boszormenyi-Nagy. Journal of Marital and Family Therapy, 44(3), 499-511.

Miller, R.B. (2000). Misconceptions about the U-shaped curve of marital satisfaction over the life course. Family Science Review, 13(1-2), 60-73.

Millings, A., Walsh, J., Hepper, E., \& O’Brien, M. (2012). Good Partner, Good Parent. Personality and Social Psychology Bulletin, 39(2), 170-180.

Monostori, J., \& Murinkó, L. (2018). Háztartás és családszerkezet. In: Monostori J., Öri P., \& Spéder Zs. (Szerk.). Demográfiai portré 2018. KSH NKI (177-197). Budapest

Morowatisharifabad, M.A., Khankolabi, M., Gerami, M.H., Fallahzade, H., MozaffariKhosravi, H., \& Seadatee-Shamir, A. (2016). Psychometric Properties of the Persian Version of Parenting Style and Dimensions Questionnaire: Application for Childrens Health-related Behaviors. International Journal of Pediatrics, 4(9), 3373-3380.

Murray, L.S., Holmes, G.J. \& Griffin, D.W. (1996). The Self-Fulfilling Nature of Positive Illusions in Romantic Relationships: Love Is Not Blind, but Prescient. Journal of Personality and Social Psychology, 71(6), 1155-1180.

Murray, L.S., Rose, P., Holmes, G.J., Derrick, J., Podchaski, E.J., Bellavia, G., \& Griffin, D.W. (2005). Putting the Partner Within Reach: A Dyadic Perspective on Felt Security in Close Relationships. Journal of Personality and Social Psychology. American Psychological Association, 88(2), 327-347.

Nanu, D.E., \& Nijloveanu, Maria, D. (2015). Attachment and Parenting Styles. Procedia. Social and Behavioral Sciences, 203, 199-204.

O'Brian, M. \& Peyton, V. (2002). Parenting attitudes and marital intimacy: A longitudinal analysis. Journal of Family Psychology 16(2), 118-127.

O'Leary, S., \& Vidair, H. (2005). Marital adjustment, child-rearing disagreements, and overreactive parenting: Predicting child behavior problems. Journal of Family Psychology, 19(2), 208-216.

Oroszné Perger, M. (2002). A szülői nevelési stílus. Iskolakultúra, 4, 107-114.

Ownsworth, T., Henderson, L., \& Chambers, S.K. (2010). Social support buffers the impact of functional impairments on caregiver psychological well-being in the context of brain tumor and other cancers. Psycho-Oncology, 19(10), 1116-1122.

Önder, A., \& Gülay, H. (2009). Reliability and validity of parenting styles \& dimensions questionnaire. Procedia Social and Behavioral Sciences, 1, 508-515.

Padilla-Walker, L.M., \& Coyne, S.M. (2011). "Turn that thing off!" parent and adolescent predictors of proactive media monitoring. Journal of Adolescence, 34, 705-715.

Papp-Zipernovszky, O., Kékesi, M.Z., \& Jámbori, Sz. (2017). A Multidimenzionális Észlelt Társas Támogatás Kérdőív magyar nyelvû́ validálása. Mentálhigiénéés Pszichoszomatika 18(3), 230-262.

Pelaez, M., Field, T., Pickens J.N., \& Hart, S. (2008). Disengaged and authoritarian parenting behavior of depressed mothers with their toddlers. Infant Behavior E Development, 31, 145-148.

Pickard, E.K., \& Ingersoll, B.R. (2015). From research settings to parents: The Role of Parent Social Networks in the Choices Parents Make About Services for Their Child With Autism Spectrum Disorder. Clinical Psychological Science, (3)2, 256-269.

Pons-Salvador, G., Cerezo, M.A., \& Trenado, R.M. (2014). Dose-effect on the mothers and babies attending the Programa de Apoyo Psicológico P/MaternoInfantil. Anales de Psicología, 30(2), 474-481.

Pulkkinen, L. (1982): Self-control and continuity from childhood to adolescence. In: P.B. Baltes, \& O.G. Brim, (Eds.), Life-span development and behavior (139-155). Vol. 4. New York: Academic Press 
Racine, N., Plamondon, A., Hentges, R., Tough, S., \& Madigan, S. (2019). Dynamic and bidirectional associations between maternal stress, anxiety, and social support: The critical role of partner and family support. Journal of Affective Disorders, 252, 19-24.

Rankin Williams, L., Degnan, K.A., Perez-Edgar, K.E., Henderson, H.A, Rubin, K.H, Pine, D.S., Steinberg, L., \& Fox, N.A. (2009). Impact of Behavioral Inhibition and Parenting Style on Internalizing and Externalizing Problems from Early Childhood through Adolescence. Journal of Abnormal Child Psychology, 37, 1063-1075.

Robinson, C.C., Mandleco, B., Olsen, S.F., \& Hart, C.H. (1995). Authoritative, authoritarian, and permissive parenting practices. Development of a new measure. Psychological Reports, 77, 819-830.

Robinson, C.C., Mandleco, B., Olsen, S.F., \& Hart, C.H. (2001). The Parenting Styles and Dimensions Questionnaire (PSDQ). In: B.F. Perlmutter, J. Touliatos, \& G.W. Holden (Eds.). Handbook of family measurement techniques: Vol. 3. Instruments E index (319-321). Thousand Oaks: Sage

Rosseel, Y. (2012). “lavaan: An R Package for Structural Equation Modeling." Journal of Statistical Software, 48(2), 1-36.

Sallay, H., \& Münnich, Á. (1999). Családi nevelési attitúdök percepciója és a self-fejlődéssel való összefüggései. Magyar Pedagógia, 99(2), 157-174.

Scanzoni, J., \& Arnett, C. (1987). Policy implications derived from a study of rural and urban marriages. Family Relations, 36, 430-436.

Schaefer, E.S. (1959). A circumplex model for maternal behavior. The Journal of Abnormal and Social Psychology, 59, 226-235.

Schaefer, E.S. (1965). A configurational analysis of children's reports of parent behavior. Journal of Consulting Psychology, 29, 552-557.

Schaefer, E.S., \& Bell, R.Q. (1958). Development of a Parental Attitude Research Instrument. Child Development, 29(3), 339-361.

Sherbourne, D.C., \& Stewart, A.L. (1991). The MOS Social Support Survey. Social Science and Medicine, 32, 705-714.

Sevinc, M., \& Garip, E.M. (2010). A study of parents' child raising styles and marital harmony, Procedia Social and Behavioral Sciences 2(2) 1648-1653.

Simon, A. (1988). A Zung-féle Önértékelő Depresszió Skála (ÖDS). In: F. Szakács (Ed.), Pszichodiagnosztikai vademecum I./1. (180-184). Budapest: Tankönyvkiadó

Sipos, K., \& Sipos, M. (1978). The development and validation of the hungarian form of the STAI. In: Spielberger, C.D., \& Diaz-Guerrerro, R. (Eds.), Cross-cultural anxiety 2. (51-61). Washington DC: Hemisphere

Song, J.I., Shin, D.W., Choi, J.Y., Kang, J., Baik, Y.J., Mo, H., \& Park, M.H. (2011). Quality of life and mental health in family caregivers of patients with terminal cancer. Supportive Care in Cancer 19(10), 1519-1526.

Spielberger, C.D., Gorsuch, R.L., \& Lushene, R.E. (1970). Manual for the State-Trait Anxiety Inventory. Palo Alto, CA: Consulting Psychologist Press

Steinberg, L., Lamborn, S.D., Darling, N., Mounts, N.S., \& Dornbusch, S.M. (1994). Overtime changes in adjustment and competence among adolescents from authoritative, authoritarian, indulgent, and neglectful families. Child Development, 65, 754-770.

Sz. Makó, H., Bernáth, L., Szentiványi-Makó, N., Veszprémi, B., Vajda, D., \& Kiss, E.Cs. (2016). A MOS SSS - Társas támasz mérésére szolgáló kérdőív magyar változatának pszichometriai jellemzői. Alkalmazott Pszichológia, 16(3),145-162.

Tagliabue, S., Olivari, M.G., Bacchini, D., Affuso, G., \& Confalonieri, E. (2014). Measuring Adolescents' Perceptions of Parenting Style During Childhood: Psychometric Properties of the Parenting Styles and Dimensions Questionnaire. Psicologia: Teoria e Pesquisa, 30(3), 251-258. 
Tagliabue, S., Olivari, M.G., Miranda, M.C., Affuso, G., Bacchini, D., \& Confalonieri, E. (2015). Memories of parenting styles and communicative processes in adolescence. Family Science, 6(1), 389-393.

Takács, Sz. (2016). Bevezetés a matematikai statisztikába: Elmélet és gyakorlat, 1. kötet, Budapest: Antarész Kiadó

Takács, Sz. (2020). Bevezetés a matematikai statisztikába: Elmélet és gyakorlat, 3. kötet. Budapest: Antarész Kiadó

Tavassolie, T., Dudding, S., Madigan, A.L., Thorvardarson, E., \& Winsler, A. (2016). Differences in perceived parenting style between mothers and fathers: implications for child outcomes and marital conflict. Journal of Child and Family Studies, 25(6), 2055-2068.

Topham, G.L., Hubbs-Tait, L., Rutledge, J.M., Page, M.C., Kennedy, T.S., Shriver, L.H., \& Harrist, A.W. (2011). Parenting styles, parental response to child emotions, and family emotional responsiveness are related to child emotional eating. Appetite, 56, 261-264.

Tóth, I., \& Gervai, J. (1999). Szülői Bánásmód Kérdőív (HPBI): A Parental Bonding Instrument (PBI) magyar változata. Magyar Pszichológiai Szemle, 54(4), 551-566.

Turney, K. (2011). Labored love: Examining the link between maternal depression and parenting behaviors. Social Science Research, 40(1), 399-415.

UNODC (2018). Global study in homicide, gender related killing of women and girls. Letöltve: 2020. 09. 30-án: https:/ / www.unodc.org/documents/data-and-analysis/GSH2018/ GSH18_Gender-related_killing_of_women_and_girls.pdf

Van den Akker, A.L., Dekovic, M., Prinzie, P., \& Asscher, J.J. (2010). Toddlers' temperament profiles: Stability and relations to negative and positive parenting. Journal of Abnormal Child Psychology, 38, 485-495.

Vera, J., Granero, R., \& Ezpeleta, L. (2012). Father's and mother's perceptions of parenting styles as mediators of the effects of parental psychopathology on antisocial behavior in outpatient children and adolescents. Child Psychiatry \& Human Development, 43, 376-392.

Waylen, A., \& Stewart-Brown, S. (2010). Factors influencing parenting in early childhood: a prospective longitudinal study focusing on change. Child: Care, Health and Development, 36, 198-207.

Weiss, L., \& Schwartz, J. (1996). The Relationship between Parenting Types and Older Adolescents' Personality, Academic Achievement, Adjustment and Substance Use. Child Development, 67, 2101-2114.

Wilhelm, K., \& Parker, G. (1988). The development of a measure of intimate bonds. Psychological Medicine, 18, 225-234.

Winnicott, D. W. (1999). Játszás és valóság. Budapest: Animula

Wu, P., Robinson, C.C., Yang, C., Hart, H.C., Olsen, F. S., Portera, L.C., Jinb, S., Wob, J., \& Wuc, X. (2002). Similarities and differences in mothers' parenting of preschoolers in China and the United States. International Journal of Behavioral Development, 26(6), 481-491.

Zung, W.W. (1965). A Self-Rating Depression Scale. Archives of General Psychiatry, 12(1), 63-70. 


\section{Köszönetnyilvánítás}

Ezúton szeretnénk köszönetet mondani a PSDQ kérdőívet rendelkezésünkre bocsátó dr. Clyde C. Robinsonnak, a kérdőívek kitöltésére időt és energiát fordító vállalkozó szellemú vizsgálati személyeknek, valamint az adatgyújtésben részt vevő, múhelymunkát és szakdolgozatot készító hallgatóknak.

Kutatásunkat a Károli Gáspár Református Egyetem kutatási pályázata finanszírozta (témaszám: 20630B800), amelynek címe: „Családi és egyéni protektív és vulnerabilitás faktorainak vizsgálata gyermek és serdülő korosztályban”. A kutatás vezetője dr. F. Földi Rita.

\section{Szerzói munkamegosztás}

Hadházi Éva: a vizsgálat és az adatgyújtés megtervezése, lebonyolítása, a kérdőív fordítása, elméleti áttekintés, adatfeldolgozás, az eredmények értelmezése, bemutatása. Takács Szabolcs: adatfeldolgozás, statisztikai számítások, az eredmények értelmezése, bemutatása. Csikós Gábor: a tanulmány megszövegezése, az eredmények prezentálása, szakirodalmi hivatkozások. Homoki Adél: adatgyújtés, az eredmények prezentálása, a szakirodalmi hivatkozások pontosítása. Czinkóczki Annamária: adatgyújtés, az eredmények prezentálása, a szakirodalmi hivatkozások pontosítása. Törő Krisztina: az eredmények prezentálása, a tanulmány megszövegezése. Kövesdi Andrea: az eredmények prezentálása, a tanulmány megszövegezése. F. Földi Rita: az eredmények prezentálása, a tanulmány megszövegezése. A végső szöveg valamennyi szerző együttes munkájának eredményeként született.

\section{Nyilatkozat érdekütközésról}

A szerzők ezúton kijelentik, hogy esetükben nem állnak fenn érdekütközések. 


\section{Függelék: Szülói Nevelói Stílus Kérdôív (PSDQ-HU)}

Alább olyan szülői viselkedések listáját találja, amelyek szülő-gyermek kapcsolatokban fordulhatnak elő. A kérdéseket annak mérésére tervezték, hogy milyen gyakran alkalmaz Ön bizonyos viselkedésformákat a gyermekével szemben. Kérem, minden kérdésre válaszoljon!

Milyen gyakran jellemző rám az adott viselkedés:

1 = soha

2 = néha

3 = az esetek felében

4 = nagyon gyakran

$5=$ mindig

A kérdésekre adott válaszát a számok bekarikázásával jelezze!

\begin{tabular}{|l|l|l|l|l|c|}
\hline 1. Nyitott vagyok gyermekem érzéseire és szükségleteire. & 1 & 2 & 3 & 4 & 5 \\
\hline 2. Fizikai büntetést alkalmazok nevelési eszközként. & 1 & 2 & 3 & 4 & 5 \\
\hline $\begin{array}{l}\text { 3. Gyermekem igényeit is figyelembe veszem, mielött } \\
\text { megkérem valamire. }\end{array}$ & 1 & 2 & 3 & 4 & 5 \\
\hline $\begin{array}{l}\text { 4. Amikor gyermekem megkérdezi, hogy miért kell } \\
\text { engedelmeskednie, azt mondom: „Azért, mert azt } \\
\text { mondtam.” vagy „Azért, mert én vagyok a szülö.” } \\
\text { vagy „Azért, mert így szeretném.” }\end{array}$ & 1 & 2 & 3 & 4 & 5 \\
\hline $\begin{array}{l}\text { 5. Elmagyarázom gyermekemnek, mit érzek, ha jól vagy } \\
\text { rosszul viselkedik. }\end{array}$ & 1 & 2 & 3 & 4 & 5 \\
\hline $\begin{array}{l}\text { 6. Elfenekelem gyermekemet, ha engedetlen. } \\
\text { 7. Bátorítom gyermekemet, hogy beszéljen a gondjairól. }\end{array}$ & 1 & 2 & 3 & 4 & 5 \\
\hline 8. Nehéznek tartom a gyermekem fegyelmezését. & 1 & 2 & 3 & 4 & 5 \\
\hline $\begin{array}{l}\text { 9. Arra biztatom a gyermekemet, hogy bátran fejezze ki, } \\
\text { ha nem ért egyet a szüleivel. }\end{array}$ & 1 & 2 & 3 & 4 & 5 \\
\hline $\begin{array}{l}\text { 10. A büntetés során kiváltságokat vonok meg } \\
\text { a gyermekemtól, és kevés vagy semennyi magyarázatot } \\
\text { sem adok. }\end{array}$ & 1 & 2 & 3 & 4 & 5 \\
\hline $\begin{array}{l}\text { 11. Nagy hangsúlyt fektetek arra, hogy megmagyarázzam } \\
\text { a szabályokat. }\end{array}$ & 1 & 2 & 3 & 4 & 5 \\
\hline $\begin{array}{l}\text { 12. Ha a gyermekemet valami felizgatja, vigasztalom } \\
\text { és megértem oot. }\end{array}$ & 1 & 2 & 3 & 4 & 5 \\
\hline
\end{tabular}




\begin{tabular}{|c|c|c|c|c|c|}
\hline $\begin{array}{l}\text { 13. Ha a gyermekem rosszalkodik, hangosan rászólok } \\
\text { vagy kiabálok. }\end{array}$ & 1 & 2 & 3 & 4 & 5 \\
\hline 14. Ha a gyermekem jól viselkedik, megdicsérem. & 1 & 2 & 3 & 4 & 5 \\
\hline $\begin{array}{l}\text { 15. Ha a gyermekem túl nagy hisztit csap valami miatt, } \\
\text { inkább engedek neki. }\end{array}$ & 1 & 2 & 3 & 4 & 5 \\
\hline 16. Dühkitöréssel reagálok a gyermekemre. & 1 & 2 & 3 & 4 & 5 \\
\hline $\begin{array}{l}\text { 17. Többször fenyegetem a gyermekemet büntetéssel, mint } \\
\text { ahányszor valóban megbüntetem. }\end{array}$ & 1 & 2 & 3 & 4 & 5 \\
\hline $\begin{array}{l}\text { 18. A családdal kapcsolatos terveimben figyelembe veszem } \\
\text { a gyermekem kívánságait is. }\end{array}$ & 1 & 2 & 3 & 4 & 5 \\
\hline $\begin{array}{l}\text { 19. Ha engedetlenül viselkedik, } \\
\text { megrázom a gyermekemet. }\end{array}$ & 1 & 2 & 3 & 4 & 5 \\
\hline $\begin{array}{l}\text { 20. Büntetést szabok ki gyermekemnek, } \\
\text { de nem tartatom be. }\end{array}$ & 1 & 2 & 3 & 4 & 5 \\
\hline $\begin{array}{l}\text { 21. Tiszteletben tartom a gyermekem véleményét azzal, } \\
\text { hogy bátorítom, mondja el azt. }\end{array}$ & 1 & 2 & 3 & 4 & 5 \\
\hline $\begin{array}{l}\text { 22. Megengedem a gyermekemnek, hogy befolyásolja } \\
\text { a családi szabályokat. }\end{array}$ & 1 & 2 & 3 & 4 & 5 \\
\hline $\begin{array}{l}\text { 23. Szidom és kritizálom a gyermekemet, } \\
\text { hogy jobbá tegyem. }\end{array}$ & 1 & 2 & 3 & 4 & 5 \\
\hline 24. Elkényeztetem a gyermekemet. & 1 & 2 & 3 & 4 & 5 \\
\hline $\begin{array}{l}\text { 25. Megmagyarázom a gyermekemnek, hogy miért kell } \\
\text { szót fogadnia. }\end{array}$ & 1 & 2 & 3 & 4 & 5 \\
\hline $\begin{array}{l}\text { 26. Inkább büntetésekkel irányítom gyermekem, } \\
\text { mint magyarázatokkal. }\end{array}$ & 1 & 2 & 3 & 4 & 5 \\
\hline $\begin{array}{l}\text { 27. Meleg és meghitt pillanatokat töltünk együtt } \\
\text { a gyermekemmel. }\end{array}$ & 1 & 2 & 3 & 4 & 5 \\
\hline $\begin{array}{l}\text { 28. Gyermekemet azzal büntetem, hogy egyedül kell } \\
\text { lennie, és kevés vagy semennyi magyarázatot sem } \\
\text { fúzök hozzá. }\end{array}$ & 1 & 2 & 3 & 4 & 5 \\
\hline $\begin{array}{l}\text { 29. Segítek a gyermekemnek megérteni, } \\
\text { hogy viselkedésének milyen hatása van, és bátorítom, } \\
\text { hogy beszéljen a cselekedete következményeiről. }\end{array}$ & 1 & 2 & 3 & 4 & 5 \\
\hline $\begin{array}{l}\text { 30. Leszidom és kritizálom gyermekemet, ha a viselkedése } \\
\text { nem felel meg az elvárásaimnak. }\end{array}$ & 1 & 2 & 3 & 4 & 5 \\
\hline $\begin{array}{l}\text { 31. Megmagyarázom a gyermekemnek a viselkedésének } \\
\text { következményeit. }\end{array}$ & 1 & 2 & 3 & 4 & 5 \\
\hline 32. Ha rosszalkodik, megpofozom a gyermekemet. & 1 & 2 & 3 & 4 & 5 \\
\hline
\end{tabular}




\title{
Skálaképzési útmutató:
}

A kérdőív nem tartalmaz fordított tételeket.

A skálák/alskálák képzése a vonatkozó tételekre adott válaszpontok átlagolásával történik.

I. Megengedó skála (5 tétel): a 8., 15., 17., 20. és 24. tételekre adott pontokat átlagoljuk.

II. Tekintélyelvú skála (az alábbi 12 tétel átlaga):

Testi fenyítés alskála (4 tétel): a 2., 6., 19. és 32. tételekre adott pontokat átlagoljuk.

Verbális ellenségesség / szidalmazás alskála (4 tétel): a 13., 16., 23. és 30. tételekre adott pontokat átlagoljuk.

Indokolatlan büntetés / büntetési stratégiák alskála (4 tétel): a 4., 10., 26. és 28. tételekre adott pontokat átlagoljuk.

III. Irányító skála (az alábbi 15 tétel átlaga):

Melegség / bevonódás alskála (5 tétel): az 1., 7., 12., 14. és 27. tételekre adott pontokat átlagoljuk.

Érvelés / magyarázatok alskála (5 tétel): az 5., 11., 25., 29. és 31. tételekre adott pontokat átlagoljuk.

Demokratikus részvétel alskála (5 tétel): a 3., 9., 18., 21. és 22. tételekre adott pontokat átlagoljuk.

\section{Measurement experience with Parenting Styles and Dimensions Questionnaire developed for identifying parenting styles}

\author{
HADHÁZI, ÉVA - TAKÁCS, SZABOLCS - CSIKÓS, GÁBOR - \\ HOMOKI, ADÉL - CZINKÓCZKI, ANNAMÁRIA - TÖRÖ, KRISZTINA \\ - KÖVESDI, ANDREA - F. FÖLDI, RITA
}

Background: Promoting the healthy physical and mental development of children is a social interest that goes beyond parental desires. Since the 1950s, there has been a strong research interest in assessing the impact of parents' parenting style on their children's development, while we have more modest research findings on the factors influencing parental style. Aim: testing the Parenting Styles and Dimensions Questionnaire (PSDQ) developed by Robinson, Mandleco, Olsen and Hart (2001) on a Hungarian sample and examining the possible sociodemographic, relationship, and psychosocial contexts of the Parenting Style. Method: In our 711-person (113 fathers, 598 mothers, mean age 34.8 [SD $=10.91$ ] years) selfreport cross-sectional study, we checked the structure and internal reliability of the PSDQ 32-item questionnaire and its subscales correlation with relationship intimacy (IBM-HU), adult attachment (ECR-RS), relationship satisfaction (RAS-H), social support (MOSS SSS), and mental well-being (STAI-T, ZUNG). Results: Due to the confirmatory factor analysis a reliable factor structure of the self- and pair-version of PSDQ-HU was confirmed (Self: SRMR $=0.065$, RMSEA $=0.059, \mathrm{TLI}=0.796, \mathrm{CFI}=0.818$; Other: $\mathrm{SRMR}=0.066, \mathrm{RMSEA}=$ 
0.063, TLI $=0.890, \mathrm{CFI}=0.902$ ). The internal reliability of the Authoritarian and Authoritative scales (Cronbach- $\alpha=0.73-0.95$ ) is adequate. Similar to international experience, the Cronbach- $\alpha$ value of the Permissive scale is lower $(0,635)$. The Physical Coercion, Verbal Hostility, Non-Reasoning, Warmth, Reasoning and Democratic Participation subscales Cronbach- $\alpha$ is between $0.54-0.93$ values. Gender, marital status, and whether someone grows up as an only child can influence the parenting style. PSDQ-HU showed significant association with multiple questionnaires $(p<0.05)$. Relationship intimacy $(r=-0.38-0,62)$, adult attachment security $(r=-0.31--0.57)$, and relationship satisfaction $(r=-0.39-0.58)$ shows correlation with the way parents perceive their partners. The scores obtained on the trait anxiety and Zung depression questionnaires correlates with the perception of the couple as more negative parents $(r=-0.33--0.38)$. Perception of stronger social support is associated with more positive parental perception of the couple $(r=0.36-0.46)$. Selfreferenced parenting style does not show a significant correlation with any of the scale variables examined. Conclusions: The questionnaire is suitable for monitoring the perception of our couple as a parent, as well perceiving ourselves as a parent. Although we examined single persons, not couples, our results draw attention to the relationship between mental state, perception of the quality of the relationship, and perception of the couple's parenting style. Our findings can provide a useful reference point for professionals working with families and couples, and in psychoeducation as well.

Keywords: parenting style, intimate bond, relationship satisfaction, adult attachment, mental well-being, social support

\footnotetext{
A cikk a Creative Commons Attribution 4.0 International License (https:/ / creativecommons.org/ licenses/by/4.0/) feltételei szerint publikált Open Access közlemény, melynek szellemében a cikk bármilyen médiumban szabadon felhasználható, megosztható és újraközölhető, feltéve, hogy az eredeti szerző és a közlés helye, illetve a CC License linkje és az esetlegesen végrehajtott módosítások feltüntetésre kerülnek. (SID_1)
} 